\section{OPEN ACCESS}

Edited by:

Yuri N. Utkin,

Institute of Bioorganic Chemistry (RAS), Russia

Reviewed by:

Sakthivel Vaiyapuri,

University of Reading, United Kingdom

Helena Safavi,

The University of Utah, United States

Zhonghua Liu,

Hunan Normal University, China

*Correspondence:

Karla de Castro Figueiredo Bordon

karla@fcfrp.usp.br

Eliane Candiani Arantes

ecabraga@fcfrp.usp.br

Specialty section:

This article was submitted to

Translational Pharmacology,

a section of the journal

Frontiers in Pharmacology

Received: 18 April 2020

Accepted: 13 July 2020

Published: 24 July 2020

Citation:

Bordon KCF, Cologna CT Fornari-Baldo EC, Pinheiro-Júnior EL, Cerni FA, Amorim FG, Anjolette FAP, Cordeiro FA, Wiezel GA, Cardoso IA,

Ferreira IG, Oliveira IS,

Boldrini-França J, Pucca MB,

Baldo MA and Arantes EC (2020)

From Animal Poisons and Venoms to Medicines: Achievements, Challenges and Perspectives in Drug Discovery.

Front. Pharmacol. 11:1132.

doi: 10.3389/fphar.2020.01132

\title{
From Animal Poisons and Venoms to Medicines: Achievements, Challenges and Perspectives in Drug Discovery
}

Karla de Castro Figueiredo Bordon ${ }^{1 *}$, Camila Takeno Cologna ${ }^{1}$, Elisa Corrêa Fornari-Baldo ${ }^{2}$, Ernesto Lopes Pinheiro-Júnior ${ }^{1}$, Felipe Augusto Cerni ${ }^{1}$, Fernanda Gobbi Amorim ${ }^{3}$, Fernando Antonio Pino Anjolette ${ }^{4}$, Francielle Almeida Cordeiro ${ }^{1}$, Gisele Adriano Wiezel ${ }^{1}$, Iara Aimê Cardoso ${ }^{1}$, Isabela Gobbo Ferreira ${ }^{1}$, Isadora Sousa de Oliveira ${ }^{1}$, Johara Boldrini-França ${ }^{5}$, Manuela Berto Pucca ${ }^{6}$, Mateus Amaral Baldo ${ }^{2}$ and Eliane Candiani Arantes ${ }^{1 *}$

\footnotetext{
${ }^{1}$ Laboratory of Animal Toxins, Department of BioMolecular Sciences, School of Pharmaceutical Sciences of Ribeirão Preto, University of São Paulo, Ribeirão Preto, Brazil, 2 Health and Science Institute, Paulista University, São José do Rio Pardo, Brazil, ${ }^{3}$ Postgraduate Program in Pharmaceutical Sciences, Vila Velha University, Vila Velha, Brazil, ${ }^{4}$ Department of Pharmacy, Federal Institute of Education, Science and Technology of Paraná, Palmas, Brazil, ${ }^{5}$ Postgraduate Program in Ecosystem Ecology, Vila Velha University, Vila Velha, Brazil, ${ }^{6}$ Medical School, Federal University of Roraima, Boa Vista, Brazil
}

Animal poisons and venoms are comprised of different classes of molecules displaying wide-ranging pharmacological activities. This review aims to provide an in-depth view of toxin-based compounds from terrestrial and marine organisms used as diagnostic tools, experimental molecules to validate postulated therapeutic targets, drug libraries, prototypes for the design of drugs, cosmeceuticals, and therapeutic agents. However, making these molecules applicable requires extensive preclinical trials, with some applications also demanding clinical trials, in order to validate their molecular target, mechanism of action, effective dose, potential adverse effects, as well as other fundamental parameters. Here we go through the pitfalls for a toxin-based potential therapeutic drug to become eligible for clinical trials and marketing. The manuscript also presents an overview of the current picture for several molecules from different animal venoms and poisons (such as those from amphibians, cone snails, hymenopterans, scorpions, sea anemones, snakes, spiders, tetraodontiformes, bats, and shrews) that have been used in clinical trials. Advances and perspectives on the therapeutic potential of molecules from other underexploited animals, such as caterpillars and ticks, are also reported. The challenges faced during the lengthy and costly preclinical and clinical studies and how to overcome these hindrances are also discussed for that drug candidates going to the bedside. It covers most of the drugs developed using toxins, the molecules that have failed and those that are currently in clinical trials. The article presents a detailed overview of toxins that have been used as therapeutic agents, including their discovery, formulation, dosage, indications, main adverse effects, and pregnancy and breastfeeding prescription warnings. Toxins in diagnosis, as well as 
cosmeceuticals and atypical therapies (bee venom and leech therapies) are also reported. The level of cumulative and detailed information provided in this review may help pharmacists, physicians, biotechnologists, pharmacologists, and scientists interested in toxinology, drug discovery, and development of toxin-based products.

Keywords: poison, venom, toxin, drug discovery, scorpion, snake, toad, Conus

\section{INTRODUCTION}

Animal poisons and venoms are rich sources of proteins, peptides, neurotransmitters, among other compounds. Together, these molecules can induce major damages in the prey's body, being one of the mechanisms employed by these animals to subdue and/ or kill their preys or predators. The main difference between the terms "poison" and "venom" is the delivery method. Poisons are generated by specialized cells or tissues or are acquired from the diet, causing prey toxicity by ingestion or contact with the poisonous animal. On the other hand, venoms are produced by a tissue or organ (venom gland) and are parenterally introduced into the prey by the venomous animal, with a specialized apparatus (fang, stinger, teeth, nematocysts, among others) (Fox and Serrano, 2007). The word "toxin" will be used for both compounds from animal poisons and venoms in the whole article.

As a result of evolution and natural selection, toxins from animal poisons and venoms display wide-ranging pharmacological activities. Since the toxin targets are related to biological functions, with many of them playing important roles in human diseases, several venom components were used in the design of new therapeutic agents. They were also employed as cosmeceuticals, diagnostic tools, and experimental molecules to validate postulated therapeutic targets, improving several drug libraries (Ghosh et al., 2019; Utkin et al., 2019).

Although several biologically active toxins have been reported from terrestrial and marine organisms, there is a large gap between the initial drug discovery phase, including their validation as drug models, and their use in a clinical study. Drug candidates must pass through an extensive range of in vitro and in vivo tests to establish their pharmacology and biochemistry, carcinogenicity, and effects on the reproductive system, to assess their safety before moving on to the clinical phases (Tamimi and Ellis, 2009). In other words, drug development includes the discovery of a candidate molecule, preclinical and clinical studies, which are usually costly and takes a significant amount of time to attend the requirements stated by the regulatory agencies throughout the world.

This review aims to highlight the key successes and some examples of the obstacles and challenges faced when developing toxin-based drugs. It covers toxins from poisonous and venomous animals, drugs that target diverse pathological conditions, the molecules that have failed, and those that are currently in clinical trials. It also aims to encourage scientists to elucidate the mechanism of action of the already known venom components, discover new molecules with innovative therapeutic potential, and develop strategies to improve their pharmacokinetic and pharmacodynamic properties. Moreover, perspectives on the research and development of a wide range of toxins from several underexploited animal poisons and venoms are also discussed.

\section{ACHIEVEMENTS WITH ANIMAL TOXIN- BASED MOLECULES}

Readers and scientists looking for approved drugs must consider the databases from regulatory agencies, such as the US Food and Drug Administration (FDA) and the European Medicines Agency (EMA). Furthermore, valuable information for health professionals and general public can be found at the Drug Information Database. However, the information provided by these databases is significantly limited, since biotechnology companies and pharmaceutical industries usually perform the drug development processes. Thus, much of the information relevant to drug development is not published and/or quite difficult to access.

Therefore, the subsections Approved Drugs to Venom Therapies will address the toxin-based approved drugs, diagnostic tools, cosmeceuticals and venom therapies, respectively, with the currently available details found at these databases.

\section{Approved Drugs}

Among the 11 approved toxin-based molecules marketed, one molecule (ziconotide) is obtained from cone snails, two from lizards (exenatide and lixisenatide), two from leeches (bivalirudin and desirudin), and six from snakes (captopril, enalapril, tirofiban, eptifibatide, batroxobin, and cobratide). Batroxobin and cobratide are native compounds purified from snake venoms, desirudin is a recombinant molecule, and the other drugs (bivalirudin, captopril, enalapril, eptifibatide, exenatide, tirofiban, and ziconotide) are synthetic molecules (Table 1).

Most toxin-based approved drugs are derived from snake venoms. One of the possible reasons for this scenario is the larger amount of venoms produced by snakes in comparison to small animals (e.g. scorpions, spiders, and snails) (King, 2011; King, 2013). In parallel, the effect of snake venoms on hemostasis evidenced the cardiovascular system as a pharmacological target for snake venom toxins. Furthermore, the analytical techniques capable of characterizing limited amounts of venom components from small animals were only developed recently. These are some issues that boosted the initial toxinological studies primarly on snake venoms. The advent of more sensitive techniques and the improvement in experimental models in the last years have allowed the study of poorly expressed toxins and their novel pharmacological targets (Boldrini-França et al., 2017). 
TABLE 1 | Approved drugs and therapies for human use.

\begin{tabular}{|c|c|c|c|c|c|c|c|c|}
\hline $\begin{array}{l}\text { Molecule } \\
\text { (brand name) }\end{array}$ & $\begin{array}{l}\text { Species } \\
\text { origin of } \\
\text { venom } \\
\text { toxin }\end{array}$ & Production & Formulation & $\begin{array}{l}\text { Mechanism } \\
\text { of action }\end{array}$ & Use & Dosage(maximum dose per day)* & $\begin{array}{l}\text { More frequently reported adverse effects, } \\
\text { pregnancy and breastfeeding warnings }{ }^{\star}\end{array}$ & Reference \\
\hline $\begin{array}{l}\text { Batroxobin } \\
\text { (Defibrase }{ }^{\circledR} \text { ) } \\
\text { (1) }\end{array}$ & $\begin{array}{l}\text { Brazilian } \\
\text { lancehead } \\
\text { snake } \\
\text { (Bothrops } \\
\text { moojeni) }\end{array}$ & $\begin{array}{l}\text { Purified from } \\
\text { venom }\end{array}$ & $\begin{array}{l}\text { Ampoule contains } 10 \\
\text { batroxobin units, } \mathrm{NaCl}, \\
\text { chlorobutanol, and partially } \\
\text { hydrolyzed gelatin in water }\end{array}$ & $\begin{array}{l}\text { Cleaves } A \alpha- \\
\text { chain of } \\
\text { fibrinogen }\end{array}$ & $\begin{array}{l}\text { Acute cerebral } \\
\text { infarction; } \\
\text { unspecific } \\
\text { angina } \\
\text { pectoris; } \\
\text { sudden } \\
\text { deafness }\end{array}$ & $\begin{array}{l}40 \text { batroxobin units by i.v. infusion } \\
\text { over } 1 \mathrm{~h} \text {. }\end{array}$ & Microvascular thrombosis & $\begin{array}{l}\text { (Stocker, } 1978 \\
\text { Vu et al., 2013; } \\
\text { Pentapharm } \\
\text { DSM } \\
\text { Nutritional } \\
\text { Products Ltd, } \\
\text { 2018) }\end{array}$ \\
\hline $\begin{array}{l}\text { Batroxobin } \\
\text { (Plateltex- } \\
\text { Act }^{\left({ }^{(}\right)}{ }^{(1)}\end{array}$ & $\begin{array}{l}\text { Common } \\
\text { lancehead } \\
\text { snake } \\
\text { (Bothrops } \\
\text { atrox) }\end{array}$ & $\begin{array}{l}\text { Purified from } \\
\text { venom }\end{array}$ & $\begin{array}{l}\text { Vial of batroxobin ( } 5 \\
\text { batroxobin units } / 1 \mathrm{ml}) \text {, and } \\
1 \text { vial of calcium gluconate } \\
\text { ( } 940 \mathrm{mg} \text { gluconate } / 10 \mathrm{ml})\end{array}$ & $\begin{array}{l}\text { Cleaves } A \alpha- \\
\text { chain of } \\
\text { fibrinogen }\end{array}$ & $\begin{array}{l}\text { Gelification of } \\
\text { blood for } \\
\text { topical } \\
\text { applications }\end{array}$ & $\begin{array}{l}1 \mathrm{ml} \text { (or maximum of } 1.5 \mathrm{ml}) \text { of } \\
\text { calcium gluconate mixed with } \\
\text { batroxobin }(5 \mathrm{U}) \text {. This mixture is mixed } \\
\text { with } 6-10 \mathrm{ml} \text { of platelet concentrate. } \\
\text { After gel formation ( } 7-10 \mathrm{~min}) \text {, it is } \\
\text { applied on the area or in the site to be } \\
\text { treated. }\end{array}$ & $\begin{array}{l}\text { No toxicity phenomena are described in the } \\
\text { tissues treated with the gel. }\end{array}$ & $\begin{array}{l}\text { (Plateltex, } \\
\text { 2018) }\end{array}$ \\
\hline $\begin{array}{l}\text { Batroxobin - } \\
\text { Fibrin } \\
\text { sealant } \\
\left.\text { (Vivostat }^{\circledR}\right)^{(1)}\end{array}$ & $\begin{array}{l}\text { Brazilian } \\
\text { lancehead } \\
\text { snake } \\
\text { (Bothrops } \\
\text { moojeni) }\end{array}$ & $\begin{array}{l}\text { Purified from } \\
\text { venom }\end{array}$ & $\begin{array}{l}\text { Medical device used for the } \\
\text { preparation of an } \\
\text { autologous fibrin; citrate }\end{array}$ & $\begin{array}{l}\text { Cleaves } A \alpha- \\
\text { chain of } \\
\text { fibrinogen }\end{array}$ & $\begin{array}{l}\text { Autologous } \\
\text { fibrin sealant } \\
\text { in surgery }\end{array}$ & $\begin{array}{l}\text { Citrate is added to the device (during } \\
\text { surgery or } 24 \mathrm{~h} \text { before), where is } \\
\text { drawn } 120 \mathrm{ml} \text { of the patient's blood. } \\
\text { After } 25 \mathrm{~min} \text {, an autologous fibrin is } \\
\text { ready for use. }\end{array}$ & The sealant has no known adverse effects. & $\begin{array}{l}\text { (Kjaergard and } \\
\text { Trumbull, } \\
\text { 1998; Vivostat } \\
\text { A/S, 2018) }\end{array}$ \\
\hline $\begin{array}{l}\text { Bee venom } \\
\text { therapy } \\
\text { (Apitox }^{\circledR} \text { ) }\end{array}$ & $\begin{array}{l}\text { Honeybee } \\
\text { Apis } \\
\text { mellifera }\end{array}$ & $\begin{array}{l}\text { Whole } \\
\text { venom }\end{array}$ & $\begin{array}{l}100 \mu \mathrm{g} / 1 \mathrm{ml} \text { (bee venom in } \\
0.9 \% \mathrm{NaCl} \text { ) }\end{array}$ & $\begin{array}{l}\text { Anti- } \\
\text { inflammatory } \\
\text { action; } \\
\text { alteration of } \\
\text { the immune } \\
\text { response via } \\
\text { antigen } \\
\text { competition }\end{array}$ & $\begin{array}{l}\text { Pain } \\
\text { associated } \\
\text { with } \\
\text { osteoarthritis } \\
\text { and multiple } \\
\text { sclerosis }\end{array}$ & $\begin{array}{l}\text { Monthly s.c. injections; twice weekly } \\
\text { range from } 1 \text { to } 20 \text { intradermal } \\
\text { injections ( } 100 \mu \mathrm{g} / 0.1 \mathrm{ml} \text { saline) -at } \\
\text { acupuncture points }\end{array}$ & $\begin{array}{l}\text { Irritation, swollen, reddened skin and severe } \\
\text { allergic reactions that can be life-threatening. }\end{array}$ & $\begin{array}{l}\text { (Gotter, 2019; } \\
\text { US National } \\
\text { Library of } \\
\text { Medicine, } \\
\text { 2020) }\end{array}$ \\
\hline $\begin{array}{l}\text { Bivalirudin } \\
\text { (Angiomax }{ }^{\circledR} \text { ) } \\
\text { (2) }\end{array}$ & $\begin{array}{l}\text { European } \\
\text { medicinal } \\
\text { leech } \\
\text { (Hirudo } \\
\text { medicinalis) }\end{array}$ & Synthetic & $\begin{array}{l}\text { Powder for injection, } 250 \\
\text { mg, (bivalirudin } \\
\text { trifluoroactetate, mannitol } \\
\text { and sodium hidroxide) }\end{array}$ & $\begin{array}{l}\text { Reversible } \\
\text { direct } \\
\text { thrombin } \\
\text { inhibitor }\end{array}$ & $\begin{array}{l}\text { Anticoagulant } \\
\text { in } \\
\text { percutaneous } \\
\text { coronary } \\
\text { intervention }\end{array}$ & $\begin{array}{l}0.75 \mathrm{mg} / \mathrm{kg} \text { by direct IV injection, } \\
\text { followed by } 1.75 \mathrm{mg} / \mathrm{kg} \text { per hour } \\
\text { (300-325 mg daily) }\end{array}$ & $\begin{array}{l}\text { Hemorragic events, back pain, pain (unspecified), } \\
\text { nausea, headache, hyper/hypotension, injection } \\
\text { site pain, insomnia, vomiting, pelvic pain, anxiety, } \\
\text { bradycardia, dyspepsia, abdominal pain, fever, } \\
\text { nervouness, urinary retention; pregnancy risk } \\
\text { factor B }\end{array}$ & $\begin{array}{l}\text { (US Food and } \\
\text { Drug } \\
\text { Administration, } \\
\text { 2020) }\end{array}$ \\
\hline $\begin{array}{l}\text { Captopril } \\
\text { (Capoten }{ }^{\circledR} \text { ) } \\
\text { (3) }\end{array}$ & $\begin{array}{l}\text { Jararaca pit } \\
\text { viper snake } \\
\text { (Bothrops } \\
\text { jararaca) }\end{array}$ & Synthetic & $\begin{array}{l}\text { Oral tablets: } 12.5,25,50, \\
\text { and } 100 \text { mg (inactive } \\
\text { ingredients: anhydrous } \\
\text { lactose, colloidal silicon } \\
\text { dioxide, crospovidone, } \\
\text { microcrystalline cellulose, } \\
\text { and stearic acid) }\end{array}$ & $\begin{array}{l}\text { Angiotensin- } \\
\text { converting } \\
\text { enzyme } \\
\text { inhibitor }\end{array}$ & $\begin{array}{l}\text { Hypertension, } \\
\text { cardiac failure }\end{array}$ & $\begin{array}{l}50 \text { or } 100 \mathrm{mg} \text { orally } 3 \text { times a day } \\
\text { (maximum dose: } 450 \mathrm{mg} / \text { day) }\end{array}$ & $\begin{array}{l}\text { Cough and skin rash; US FDA pregnancy } \\
\text { category D; excreted into human milk- } \\
\text { discontinue breastfeeding or discontinue the } \\
\text { drug, since the effects in the nursing infant are } \\
\text { unknown }\end{array}$ & $\begin{array}{l}\text { (US Food and } \\
\text { Drug } \\
\text { Administration, } \\
\text { 2020) }\end{array}$ \\
\hline $\begin{array}{l}\text { Cobratide } \\
\text { (Ketongning, }\end{array}$ & $\begin{array}{l}\text { Chinese } \\
\text { cobra (Naja } \\
\text { naja atra) }\end{array}$ & $\begin{array}{l}\text { Purified from } \\
\text { venom }\end{array}$ & $\begin{array}{l}\text { Freeze-dried powder ( } 70 \text { or } \\
140 \mu \mathrm{g} / \mathrm{vial} \text { ) with dextran } \\
\text { and glycine as excipient, for }\end{array}$ & $\begin{array}{l}\text { Blockage of } \\
\text { nicotinic } \\
\text { receptors }\end{array}$ & $\begin{array}{l}\text { Chronic } \\
\text { arthralgia, } \\
\text { sciatica, }\end{array}$ & $\begin{array}{l}\text { Minimum and maximum daily dose are } \\
280 \mu \mathrm{g} \text { and } 840 \mu \mathrm{g} \text {, respectively - }\end{array}$ & $\begin{array}{l}\text { Fatal side effects, such as respiration inhibition, } \\
\text { can } \\
\text { occur when it is injected at higher dosage levels. }\end{array}$ & $\begin{array}{l}\text { (Chen et al., } \\
\text { 2016; } \\
\text { Orientoxin }\end{array}$ \\
\hline
\end{tabular}




\begin{tabular}{|c|c|c|c|c|c|c|c|c|}
\hline $\begin{array}{l}\text { Molecule } \\
\text { (brand name) }\end{array}$ & $\begin{array}{l}\text { Species } \\
\text { origin of } \\
\text { venom } \\
\text { toxin }\end{array}$ & Production & Formulation & $\begin{array}{l}\text { Mechanism } \\
\text { of action }\end{array}$ & Use & Dosage(maximum dose per day) ${ }^{*}$ & $\begin{array}{l}\text { More frequently reported adverse effects, } \\
\text { pregnancy and breastfeeding warnings* }\end{array}$ & Reference \\
\hline $\begin{array}{l}\text { cobrotoxin) } \\
\text { (2) }\end{array}$ & & & $\begin{array}{l}\text { injection and cobratide } \\
\text { enteric coated capsule }\end{array}$ & & $\begin{array}{l}\text { neuropathic } \\
\text { headache }\end{array}$ & $\begin{array}{l}\text { enteric coated capsule } \\
\text { (CN101381408B) }\end{array}$ & & $\begin{array}{l}\text { Biotech Co. } \\
\text { Ltd., 2019) }\end{array}$ \\
\hline $\begin{array}{l}\text { Desirudin } \\
\left.\text { (Iprivask }^{\circledR}\right)^{(2)}\end{array}$ & $\begin{array}{l}\text { European } \\
\text { medicinal } \\
\text { leech } \\
\text { (Hirudo } \\
\text { medicinalis) }\end{array}$ & Recombinant & $\begin{array}{l}\text { Sterile powder for injection } \\
\text { (desirudin-15.75 mg, } \\
\text { anhydrous magnesium } \\
\text { chloride- } 1.31 \mathrm{mg} \text {, and } \\
\text { sodium hydroxide for } \\
\text { injection USP) }\end{array}$ & $\begin{array}{l}\text { Selective and } \\
\text { near- } \\
\text { irreversible } \\
\text { inhibitor of } \\
\text { thrombin }\end{array}$ & $\begin{array}{l}\text { Prevention of } \\
\text { venous } \\
\text { thrombotic } \\
\text { events }\end{array}$ & $\begin{array}{l}15 \mathrm{mg} \text { ( } 5-15 \mathrm{~min} \text { prior surgery), } \\
\text { followed by } 15 \mathrm{mg} \text { every } 12 \mathrm{~h} \text { up to } \\
12 \text { days }\end{array}$ & $\begin{array}{l}\text { Bleeding, deep vein thrombophlebitis, wound } \\
\text { secretion, nausea, vomiting, fever, hematoma, } \\
\text { anemia; pregnancy risk factor C; no } \\
\text { breastfeeding when using desirudin }\end{array}$ & $\begin{array}{l}\text { (US Food and } \\
\text { Drug } \\
\text { Administration, } \\
\text { 2020) }\end{array}$ \\
\hline $\begin{array}{l}\text { Enalapril } \\
\left.\text { (Vasotec }^{\circledR}\right)^{(3)}\end{array}$ & $\begin{array}{l}\text { Jararaca pit } \\
\text { viper snake } \\
\text { (Bothrops } \\
\text { jararaca) }\end{array}$ & Synthetic & $\begin{array}{l}\text { Oral Tablets, } 2.5,5,10 \text {, and } \\
20 \mathrm{mg} ; 1.25 \mathrm{mg} / \mathrm{ml} \mathrm{i.v.} \mathrm{(with} \\
\text { benzyl alcohol } 0.9 \% \text { ) }\end{array}$ & $\begin{array}{l}\text { Angiotensin- } \\
\text { converting } \\
\text { enzyme } \\
\text { inhibitor }\end{array}$ & $\begin{array}{l}\text { Hypertension, } \\
\text { cardiac failure }\end{array}$ & $\begin{array}{l}2.5 \mathrm{mg} \text { twice daily up to } 10-20 \mathrm{mg} \\
\text { twice daily. Increased dosage up to } 40 \\
\mathrm{mg} / \text { day ( } 1 \text { or } 2 \text { divided doses) }\end{array}$ & $\begin{array}{l}\text { Increased serum creatinine,hypotension, } \\
\text { dizziness, headache, fatigue, skin rash, } \\
\text { abdominal pain, anorexia, constipation, diarrhea, } \\
\text { nausea, vomiting, cough, dyspnea; US FDA } \\
\text { pregnancy category D; excreted into human milk } \\
\text { - discontinue breastfeeding or discontinue the } \\
\text { drug, since the effects in the nursing infant are } \\
\text { unknown }\end{array}$ & $\begin{array}{l}\text { (US Food and } \\
\text { Drug } \\
\text { Administration, } \\
\text { 2020) }\end{array}$ \\
\hline $\begin{array}{l}\text { Eptifibatide } \\
\text { (Integrilin }{ }^{\circledR} \text { ) } \\
\text { (2) }\end{array}$ & $\begin{array}{l}\text { Pigmy } \\
\text { rattlesnake } \\
\text { (Sistrurus } \\
\text { miliarius) }\end{array}$ & Synthetic & $\begin{array}{l}\text { I.v. bolus injection ( } 20 \mathrm{mg} / \\
10 \mathrm{ml}) \text {; i.v. infusion }(75 \mathrm{mg} / \\
100 \mathrm{ml}) \text {; i.v. infusion ( } 200 \\
\mathrm{mg} / 100 \mathrm{ml}) ; \text { Each vial of } \\
\text { any dose also contains } 5.25 \\
\mathrm{mg} / \mathrm{ml} \text { citric acid and } \mathrm{NaOH} \\
\text { to adjust to } \mathrm{pH} 5.35 \text {. }\end{array}$ & $\begin{array}{l}\text { Prevents } \\
\text { binding of } \\
\text { fibrinogen, } \\
\text { von } \\
\text { Willebrand } \\
\text { factor, and } \\
\text { other } \\
\text { adhesive } \\
\text { ligands to } \\
\text { GPIllb/llla }\end{array}$ & $\begin{array}{l}\text { Acute } \\
\text { coronary } \\
\text { syndrome; } \\
\text { percutaneous } \\
\text { coronary } \\
\text { intervention }\end{array}$ & $\begin{array}{l}\text { Initial dose of } 180 \mu \mathrm{gg} / \mathrm{kg} \text { intravenous } \\
\text { bolus administered and for } \\
\text { maintenance } 2 \mu \mathrm{gg} / \mathrm{kg} / \mathrm{min} \text { by a } \\
\text { continuous infusion until hospital } \\
\text { discharge, or for up } 18 \text { to } 24 \mathrm{~h} \text {, } \\
\text { whichever comes first. A minimum of } \\
12 \mathrm{~h} \text { of infusion is recommended by } \\
\text { the manufacturer. }\end{array}$ & $\begin{array}{l}\text { Bleeding, dizziness; US FDA pregnancy category } \\
\text { B; not known if distributed into human milk }\end{array}$ & $\begin{array}{l}\text { (RxList, 2019; } \\
\text { European } \\
\text { Medicines } \\
\text { Agency, 2020) }\end{array}$ \\
\hline $\begin{array}{l}\text { Exenatide } \\
\left.\text { (Byetta }^{\circledR}\right)^{(2)}\end{array}$ & $\begin{array}{l}\text { Gila } \\
\text { monster } \\
\text { lizard } \\
\text { (Heloderma } \\
\text { suspectum) }\end{array}$ & Synthetic & $\begin{array}{l}\text { Prefilled cartridge pen ( } 250 \\
\mu \mathrm{g} / \mathrm{ml} \text {; s.c. injection) }\end{array}$ & $\begin{array}{l}\text { Glucagon-like } \\
\text { peptide-1 } \\
\text { receptor } \\
\text { agonist }\end{array}$ & $\begin{array}{l}\text { Type } 2 \\
\text { diabetes } \\
\text { mellitus }\end{array}$ & $\begin{array}{l}5 \text { or } 10 \mu \mathrm{g} \text { twice daily } 60 \mathrm{~min} \text { before } \\
\text { two main meals of the day, } \sim 6 \mathrm{~h} \text { apart }\end{array}$ & $\begin{array}{l}\text { Hypoglycemia, nausea, vomiting, diarrhea, jittery } \\
\text { feeling, dizziness, headache, dyspepsia, asthenia, } \\
\text { gastroesophageal reflux disease, hyperhidrosis, } \\
\text { constipation, abdominal distention, decreased } \\
\text { appetite, flatulence; data lacking on the use in } \\
\text { pregnancy; not known if excreted into human } \\
\text { milk }\end{array}$ & $\begin{array}{l}\text { (US Food and } \\
\text { Drug } \\
\text { Administration, } \\
\text { 2020) }\end{array}$ \\
\hline $\begin{array}{l}\text { Extended- } \\
\text { release } \\
\text { exenatide } \\
\text { (Bydureon }{ }^{\circledR} \text { ) } \\
\text { (2) }\end{array}$ & $\begin{array}{l}\text { Gila } \\
\text { monster } \\
\text { lizard } \\
\text { (Heloderma } \\
\text { suspectum) }\end{array}$ & Synthetic & $\begin{array}{l}\text { Exenatide }(2 \mathrm{mg}) \text { and } \\
\text { diluent }\end{array}$ & $\begin{array}{l}\text { Glucagon-like } \\
\text { peptide-1 } \\
\text { receptor } \\
\text { agonist }\end{array}$ & $\begin{array}{l}\text { Type } 2 \\
\text { diabetes } \\
\text { mellitus }\end{array}$ & $\begin{array}{l}2 \mathrm{mg} \text { weekly at any time of the dosing } \\
\text { day, with or without meals }\end{array}$ & $\begin{array}{l}\text { Hypoglycemia, nausea, diarrhea, injection-site } \\
\text { reactions (pruritus, nodule, erythema, } \\
\text { hematoma), vomiting, constipation, headache, } \\
\text { viral gastroenteritis, gastroesophageal reflux } \\
\text { disease, dyspepsia, fatigue, decreased appetite; } \\
\text { data lacking on the use in pregnancy; not known } \\
\text { if excreted into human milk }\end{array}$ & $\begin{array}{l}\text { (European } \\
\text { Medicines } \\
\text { Agency, 2020; } \\
\text { US Food and } \\
\text { Drug } \\
\text { Administration, } \\
\text { 2020) }\end{array}$ \\
\hline $\begin{array}{l}\text { Leech } \\
\text { therapy }\end{array}$ & $\begin{array}{l}\text { European } \\
\text { medicinal } \\
\text { leech }\end{array}$ & Leech & $\begin{array}{l}\text { Leeches drain blood from } \\
\text { tissue }\end{array}$ & $\begin{array}{l}\text { Inhibits } \\
\text { platelet } \\
\text { aggregation }\end{array}$ & $\begin{array}{l}\text { Skin grafts } \\
\text { and }\end{array}$ & $\begin{array}{l}\text { Usually } 1-10 \text { leeches are used for } \\
\text { each treatment, while at the beginning, } \\
\text { the patient might need two or more }\end{array}$ & $\begin{array}{l}\text { Lymphadenitis, slight swelling, pain of regional } \\
\text { lymph nodes on the side of leech application and } \\
\text { subfebrile temperature. Leech therapy is not }\end{array}$ & $\begin{array}{l}\text { (Mumcuoglu, } \\
\text { 2014; US Food } \\
\text { and Drug }\end{array}$ \\
\hline
\end{tabular}




\begin{tabular}{|c|c|c|c|c|c|c|c|c|}
\hline $\begin{array}{l}\text { Molecule } \\
\text { (brand name) }\end{array}$ & $\begin{array}{l}\text { Species } \\
\text { origin of } \\
\text { venom } \\
\text { toxin }\end{array}$ & Production & Formulation & $\begin{array}{l}\text { Mechanism } \\
\text { of action }\end{array}$ & Use & Dosage(maximum dose per day) ${ }^{\star}$ & $\begin{array}{l}\text { More frequently reported adverse effects, } \\
\text { pregnancy and breastfeeding warnings }{ }^{\star}\end{array}$ & Reference \\
\hline & $\begin{array}{l}\text { (Hirudo } \\
\text { medicinalis) } \\
\text { or other } \\
\text { species }\end{array}$ & & & $\begin{array}{l}\text { and the } \\
\text { coagulation } \\
\text { cascade }\end{array}$ & $\begin{array}{l}\text { reattachment } \\
\text { surgery }\end{array}$ & $\begin{array}{l}\text { treatments per day. Leeches should } \\
\text { be applied on the darker spots of the } \\
\text { reattached body parts or flaps. Usually } \\
\text { the treatment lasts for } 2-6 \text { days. }\end{array}$ & $\begin{array}{l}\text { recommended in pregnancy, lactation and in } \\
\text { patients with an unstable medical status and } \\
\text { disposition to keloid scar formation. }\end{array}$ & $\begin{array}{l}\text { Administration, } \\
\text { 2020) }\end{array}$ \\
\hline $\begin{array}{l}\text { Lixisenatide } \\
\text { (Lyxumia }^{\circledR} \\
\text { and } \\
\left.\text { Adlyxin }^{\circledR}\right)^{(2)}\end{array}$ & $\begin{array}{l}\text { Gila } \\
\text { monster } \\
\text { lizard } \\
\text { (Heloderma } \\
\text { suspectum) }\end{array}$ & Synthetic & $\begin{array}{l}0.15 \mathrm{mg} / 3 \mathrm{ml}(0.05 \mathrm{mg} / \mathrm{ml}) \\
- \text { s.c. } \\
0.3 \mathrm{mg} / 3 \mathrm{ml}(0.1 \mathrm{mg} / \mathrm{ml})- \\
\text { s.c. }\end{array}$ & $\begin{array}{l}\text { Glucagon-like } \\
\text { peptide-1 } \\
\text { receptor } \\
\text { agonist }\end{array}$ & $\begin{array}{l}\text { Type } 2 \\
\text { diabetes } \\
\text { mellitus }\end{array}$ & $\begin{array}{l}\text { Initial dose: } 10 \mu \mathrm{g} \text { by s.c. injection } \\
\text { once a day. Increase to } 20 \mu \mathrm{g} \text { on day } \\
\text { 15. This drug should be administered } \\
1 \mathrm{~h} \text { before the first meal of the day. } \\
\text { Concurrent use with short acting } \\
\text { insulin has not been studied and is not } \\
\text { recommended. }\end{array}$ & $\begin{array}{l}\text { Nausea, vomiting, diarrhea, headache, dizziness, } \\
\text { low blood sugar; data lacking on the use in } \\
\text { pregnancy; not known if distributed into human } \\
\text { milk, but its use is not recommended. }\end{array}$ & $\begin{array}{l}\text { (European } \\
\text { Medicines } \\
\text { Agency, 2020; } \\
\text { US Food and } \\
\text { Drug } \\
\text { Administration, } \\
\text { 2020) }\end{array}$ \\
\hline $\begin{array}{l}\text { Tirofiban } \\
\text { (Aggrastat }{ }^{\circledR} \text { ) } \\
\text { (3) }\end{array}$ & $\begin{array}{l}\text { Saw-scaled } \\
\text { viper snake } \\
\text { (Echis } \\
\text { carinatus) }\end{array}$ & Synthetic & $\begin{array}{l}\text { I.v. bolus ( } 3.75 \mathrm{mg} \text { in } 15 \mathrm{ml} \\
\text { - vial); i.v. bolus and } \\
\text { infusion ( } 5 \mathrm{mg} \text { in } 100 \mathrm{ml}- \\
\text { vial); i.v. bolus and infusion } \\
(12.5 \mathrm{mg} / 250 \mathrm{ml}-\text { bag) }\end{array}$ & $\begin{array}{l}\text { Antagonist of } \\
\text { fibrinogen } \\
\text { binding to the } \\
\text { GPllb/llla } \\
\text { receptor }\end{array}$ & $\begin{array}{l}\text { Acute } \\
\text { coronary } \\
\text { syndrome }\end{array}$ & $\begin{array}{l}\text { Initial dose: } 25 \mu \mathrm{g} / \mathrm{kg} \text { i.v. within } 5 \mathrm{~min} \text {. } \\
\text { Maintenance dose: } 0.15 \mu \mathrm{g} / \mathrm{kg} / \mathrm{min} \text { i.v. } \\
\text { infusion for up to } 18 \mathrm{~h}\end{array}$ & $\begin{array}{l}\text { Dizziness, slow heart rate, leg pain, pelvic pain, } \\
\text { swelling, increased sweating; US FDA pregnancy } \\
\text { category B; not known if distributed into human } \\
\text { milk. }\end{array}$ & $\begin{array}{l}\text { (Medicure } \\
\text { Pharma, 2016) }\end{array}$ \\
\hline $\begin{array}{l}\text { Ziconotide } \\
\left.\text { (Prialt }^{\mathrm{Q}}\right)^{(2)}\end{array}$ & $\begin{array}{l}\text { Magical } \\
\text { cone } \\
\text { marine snail } \\
\text { (Conus } \\
\text { magus) }\end{array}$ & Synthetic & $\begin{array}{l}25 \text { or } 100 \mu \mathrm{g} / \mathrm{ml} \text { (aqueous } \\
\mathrm{pH} \text { adjusted solution } \mathrm{pH} 4- \\
5, \mathrm{~L}-\text {-methionine and } \mathrm{NaCl}) \text {; } \\
\text { i.t. }\end{array}$ & $\begin{array}{l}\text { Cav2.2 } \\
\text { channel } \\
\text { antagonist }\end{array}$ & $\begin{array}{l}\text { Severe } \\
\text { chronic pain }\end{array}$ & $\begin{array}{l}\text { Initial dose: } \leq 2.4 \mu \mathrm{g} / \text { day }(\leq 0.1 \mu \mathrm{g} / \mathrm{h}) \\
\text { less than } 2 \text { to } 3 \text { times/week. Maximum } \\
\text { dose: } 19.2 \mu \mathrm{g} / \text { day }(0.8 \mu \mathrm{g} / \mathrm{h}) \text { by day } \\
21 .\end{array}$ & $\begin{array}{l}\text { Dizziness, confusion, drowsiness,abnormal gait, } \\
\text { memory impairment, ataxia, speech disorder, } \\
\text { headache, aphasia, hallucination, thinking } \\
\text { abnormality, amnesia, anxiety, blurred vision, } \\
\text { increased creatine phosphokinase, anorexia, } \\
\text { nystagmus, fever; pregnancy risk factor C }\end{array}$ & $\begin{array}{l}\text { (US Food and } \\
\text { Drug } \\
\text { Administration, } \\
\text { 2020) }\end{array}$ \\
\hline
\end{tabular}

*For complete and detailed information, we suggest consulting Drugs.com and the patient information leaflets provided by the medicine manufacturer; 1), enzyme; 2), peptide; 3), non-protein molecule; i.t., intrathecal; i.v., intravenous; s.c. subcutaneous. 
Additionally, the discovery of many ion channels in the 19701980s, and the better understanding of the nervous system, which houses the main molecular targets of small venomous invertebrates, opened up the field to new therapeutic leads for non-cardiovascular targets (King, 2013).

The first animal toxin-based drug approved for human use was captopril in 1981. Captopril (Capoten ${ }^{\circledR}$, Bristol-Myers Squibb) was developed based on the bradykinin potentiating factor (BPF) present in Bothrops jararaca snake venom (Ferreira, 1965; Camargo et al., 2012). BPF is a nonapeptide that acts by blocking the activity of the angiotensin-converting enzyme (ACE), inhibiting the production of the hypertensive molecule angiotensin II and potentiating the action of the hypotensive peptide bradykinin (Ferreira, 1965; Ferreira and Rocha e Silva, 1965; Ferreira et al., 1970a; Ferreira et al., 1970b).

Since the native peptide found in this venom was quite expensive to be synthesized and impossible to be orally administered (Ferreira, 2000), captopril was designed by the miniaturization of the original molecule, and by the addition of a succinyl group to a proline residue, which allowed its oral administration. This amino acid residue located at the $\mathrm{C}$ terminal of BPP5a (one of the most active peptides in the bradykinin potentiating factor) is responsible for interacting with ACE (Cushman et al., 1977; Camargo et al., 2012). Captopril (alone or in combination with other drugs) is suitable and widely used for hypertension treatment (Weber et al., 2014).

After captopril, enalapril (MK-421, enalapril maleate) was approved by the FDA in 1985 for hypertension and congestive heart failure treatments (Patchett, 1984). The mercapto group in captopril structure was believed to be responsible for the skin rash and loss of taste reported as common adverse effects when using this drug. Therefore, the main challenge in enalapril development was to substitute the mercapto by an alkyl group, keeping the interaction with ACE (Patchett, 1984). Enalapril (Vasotec ${ }^{\circledR}$, Merck) is produced as a prodrug that undergoes in vivo de-esterification to give rise to enalaprilat (MK-422), whose potency is greater than captopril, but has limited oral bioavailability (Biollaz et al., 1981; Patchett, 1984). Historically, captopril and enalapril are the hallmark in the development of ACE inhibitors for the treatment of hypertension.

The antiplatelet drug tirofiban (Aggrastat ${ }^{\circledR}$, Medicure International, Inc.) is based on the RGD motif (Arg-Gly-Asp) from echistatin, a disintegrin found in the venom of the sawscaled viper Echis carinatus (Topol et al., 1999). Tirofiban was approved by the FDA in 1998 for acute coronary syndrome treatment (Hartman et al., 1992). It mimics the RGD sequence and possesses a $(\mathrm{S})-\mathrm{NHSO}_{2}-\mathrm{C}_{4} \mathrm{H}_{9}$ group that enhanced the interactions with the platelet glycoprotein GPIIb/IIIa receptor (Gan et al., 1988). The competition with fibrinogen for the RGD recognition sites on the GPIIb/IIIa complex results in the inhibition of platelet aggregation and other antithrombotic properties (Topol et al., 1999; Lang et al., 2012).

Eptifibatide (Integrilin ${ }^{\circledR}$, Millennium Pharmaceuticals, Inc.) is another antiplatelet drug approved by the FDA in 1998 and licensed to Schering-Plough in 2005. It was developed during the efforts to create synthetic analogues of barbourin, a disintegrin isolated from Sistrurus miliarius barbouri snake venom. Due to its conservative amino acid substitution of arginine (R) for lysine $(\mathrm{K})$, barbourin presents more specificity for platelet glycoprotein GPIIb/IIIa complex than other disintegrins containing the RGD motif (Scarborough et al., 1991). Also, it was verified that the affinity for GPIIb/IIIa is highly influenced by the amino acid residues adjacent to the KGD sequence and the size of the peptide ring created through the disulfide bond formation. From this information, different synthetic peptides with potential clinical use were designed, including eptifibatide (Scarborough, 1999). Eptifibatide is a cyclic heptapeptide (deamino-Cys(1)-hArg-Gly-Asp-Trp-Pro-Cys(1)- $\mathrm{NH}_{2}$ ) more resistant to proteolysis due the introduction of a ring in the structure (Scarborough et al., 1993; Tcheng and O'Shea, 2002).

In the middle of 1900s, hirudin was isolated from Hirudo medicinalis leech saliva (Lee and Ansell, 2011). This 65-amino acid peptide presents an anticoagulant effect, through direct thrombin inhibition, and it was the only molecule to prevent blood coagulation until the discovery of heparin (Dodt et al., 1984; Markwardt, 1991). The removal of a sulfate group at Tyr63 residue gave rise to desulfatohirudin and increased in 10 times the complex formation with thrombin; however, obtaining this molecule with high activity and yield was a challenge to be overcome to allow clinical studies (Johnson et al., 1989; Markwardt, 1991). Desirudin (Iprivask ${ }^{\circledR}$, Bausch Health), the recombinant 63-desulfohirudin (variant $\mathrm{HV}-1$ ) produced in Saccharomyces cerevisiae (strain TR 1456), was approved by the FDA in 2003 for prophylaxis of deep vein thrombosis after hip replacement surgery (Warkentin, 2004). Revasc ${ }^{\circledR}$ (Novartis) was approved by EMA in 1997, but it was withdrawn from the market in 2014 for commercial reasons.

In general, hirudins inactivate irreversibly thrombin, causing more bleeding than heparin (Römisch et al., 1993). Therefore, some analogues were developed with the aim of optimizing the therapeutic profile of hirudin based on the interaction with the active site of thrombin (Warkentin, 2004). Bivalirudin (Angiomax ${ }^{\circledR}$, The Medicines Company) is a synthetic peptide resulted from rational drug design, comprised of 20 amino acids: $4 \mathrm{~N}$-terminal residues from native hirudin which interact with the active site, connected by 4 glycine residues to the last 12 residues present in its $\mathrm{C}$-terminal responsible to interact with the anion exosite (Maraganore et al., 1990). This drug binds reversibly to thrombin, which decreased the risk of bleeding reported to other hirudins (Nutescu and Wittkowsky, 2004). Angiomax ${ }^{\circledR}$ was approved by the FDA in 2000 to patients with unstable angina undergoing percutaneous transluminal coronary angioplasty (Bittl et al., 2001). In Europe it is marketed as Angiox $^{\circledR}$ (Mehrzad et al., 2017).

In 2004, ziconotide (Prialt $^{\circledR}$, Elan Pharmaceuticals, Inc.) was approved for the management of severe chronic pain by the FDA and by the EMA (Smith and Deer, 2009). Ziconotide (SNX-111) is a synthetic analogue of the omega-conotoxin MVIIA isolated from the venom of the fish-hunting snail Conus magus. It is a 25amino acid peptide that blocks $\mathrm{Ca}_{\mathrm{v}} 2.2$ channels (N-type voltagesensitive calcium channels) and, consequently, inhibits the 
conduction of nerve impulse and release of neurotransmitters into the thalamus, leading to antinociception (McGivern, 2007; Vink and Alewood, 2012). Ziconotide does not induce dependence or tolerance, which is a valuable advantage in comparison to morphine, which is also less effective than ziconotide (Scott et al., 2002). However, the main limitations of ziconotide use are its intrathecal administration route, which impairs the patient's adherence to the treatment (Smith and Deer, 2009), and narrow therapeutic index (Scott et al., 2002). Recently, the intranasal route has been studied to overcome the challenge of administering ziconotide (Manda et al., 2016).

Exenatide (synthetic exendin-4 from Gila monster, Heloderma suspectum) is the first glucagon-like-peptide-1 (GLP-1) analogue (Furman, 2012) and has been used as an adjuvant in the treatment of type 2 diabetes mellitus (Nauck et al., 2007; Henry et al., 2014). It presents a combination of actions: stimulation of insulin and suppression of glucagon secretion that result in blood glucose control, and reduction of body weight and cardiovascular risk factors (Eng et al., 1992; Greig et al., 1999; Alves et al., 2017).

Since GLP-1 is rapidly degraded by serum proteases presenting a very short lifetime, the key point was the development of GLPlanalogues resistant to these enzymes (Lorenz et al., 2013). Indeed the N-terminal (HGE) of exendin- 4 is more resistant to peptidases that degrade the endogenous GLP-1 which make that more potent and longer-lasting than GLP-1 (Eng et al., 1992; Greig et al., 1999). The first pharmaceutical form of exenatide (Byetta ${ }^{\circledR}$ ) was approved by the FDA in 2005 and in 2009 by the EMA. Even with the N-terminal more resistant to proteases, Byetta ${ }^{\circledR}$ has a half-life of $\sim 2.4 \mathrm{~h}$ after administration (Lorenz et al., 2013).

Lixisenatide (Lyxumia ${ }^{\circledR}$ in the Europe and Adlyxin ${ }^{\circledR}$ in the USA., Sanofi S.A.) is a 44-amino acid peptide, with an amide group on its C-terminus. It is comprised of the first 39 amino acids of exendin-4, with a deletion of proline at position 38 and addition of six lysine residues (Christensen et al., 2009). Lixisenatide was approved in 2013 and 2016 by the EMA and the FDA, respectively, as the first once-daily injectable GLP-1 receptor agonist for the treatment of diabetes type II, presenting a half-life of $\sim 3$ h (Elkinson and Keating, 2013; Lorenz et al., 2013; US Food and Drug Administration, 2016).

In addition, there is an extended-release form of exenatide (Bydureon $^{\circledR}$ ), approved in 2011 and 2012 by the EMA and the FDA, respectively. It has a half-life of 5-6 days due to its encapsulation into poly (D,L-lactide-co-glycolide) microspheres, which hydrate in situ and slowly degrade to release the drug over time, resulting in less peak-trough variation (DeYoung et al., 2011; Lorenz et al., 2013). Long-acting exenatide has also been developed in a ready-to-use auto injector to facilitate the administration since the former pharmaceutical form needs to be diluted prior to administration (Wysham et al., 2017).

Apart from the marketed drugs in the USA and Europe, there are also those approved by the National Medical Products Administration (NMPA, formerly State FDA and China FDA -SFDA and CFDA, respectively). Batroxobin (also known as hemocoagulase, reptilase, and botropase) is a thrombin-like serine protease obtained from $B$. atrox and B. moojeni snake venoms (Itoh et al., 1987; Earps and Shoolingin-Jordan, 1998). It cleaves fibrinogen, resulting in the formation of non-cross-linked fibrin clots. Unlike thrombin, which releases fibrinopeptides A and B from fibrinogen, batroxobin releases only fibrinopeptide A (Holleman and Weiss, 1976). Although the enzyme is not clinically approved in the USA, its defibrinogenating effect is clinically used in other countries for the treatment of various thrombotic diseases including deep vein thrombosis, myocardial infarction, pulmonary embolism, and acute ischemic stroke (You et al., 2004).

Currently, batroxobin has been commercialized with the brand names: Batroxobin and Reptilase (Tobishi Pharmaceutical, China), Defibrase (Tobishi Pharmaceutical, China and DSM Nutritional Products Ltd Branch Pentapharm, Switzerland), Botropase (Hanlim, South Korea and Juggat Pharma, India), Botroclot (Juggat Pharma, India) (Drugs.com, 2020), Plateltex-Act ${ }^{\circledR}$ (Plateltex S.R.O., Czech Republic) (Plateltex, 2018), and Vivostat System (Vivostat A/S, 2018). Therapeutic applications of Defibrase ${ }^{\circledR}$ include acute cerebral infarction, unspecific angina pectoris, and sudden deafness (Pentapharm DSM Nutritional Products Ltd, 2018). Plateltex-Act ${ }^{\circledR}$ is used to prepare autologous platelet-gel, an emerging biotechnology in current tissue engineering and cellular therapy (Mazzucco et al., 2008). Batroxobin from Plateltex-Act ${ }^{\circledR}$ converts fibrinogen into fibrin in the presence of $\mathrm{Ca}^{2+}$ ions, and forms a fibrin reticulum that causes the gelling of the product and cooperates with the regenerative and reparative processes of damaged tissues (Mazzucco et al., 2008; Plateltex, 2016). The Vivostat System (Vivostat A/S, Denmark) is a medical device used for the preparation of an autologous fibrin sealant in the operating room by the action of batroxobin upon the fibrinogen in the patient's plasma (Vivostat A/S, 2018).

In 1998, cobratide (a short-chain post-synaptic $\alpha$-neurotoxin isolated from Naja naja atra snake venom, also known as ketongning and cobrotoxin) was approved in combination with synthetic drugs as a pain killer for the treatment of moderate to severe pain (Gazerani and Cairns, 2014; Zhang, 2015). However, pharmacokinetics studies in vivo of cobratide injection (China Approval no. H53022101) are still necessary to adjust drug plasma concentrations and to reduce the risk of drug accumulation and fatal side effects (e.g., respiration inhibition) (Chen et al., 2016).

A detailed description of mechanism, pharmacology, pharmacokinetics, and clinical development of most approved toxin-based drugs can be found in specific reviews already published for each compound (Brogden et al., 1988; Tabacova and Kimmel, 2001; Wong, 2005; Zeymer, 2007; Graetz et al., 2011; Pope and Deer, 2013; Serrano, 2013; Knop et al., 2017; Trujillo and Goldman, 2017; Yang et al., 2019).

\section{Diagnostic Tools}

Besides its therapeutic applications, batroxobin (Reptilase ${ }^{\circledR}$ ) has also been used for decades as a laboratory reagent to measure fibrinogen levels and blood coagulation capability through the in vitro clotting time using serine proteases instead of thrombin (Reptilase ${ }^{\circledR}$ time) (Funk et al., 1971). Since Reptilase ${ }^{\circledR}$ does not need $\mathrm{Ca}^{2+}$ and phospholipids, some coagulation factors (V, VIII, $\mathrm{XI}$, and XIII) are not activated and the platelet aggregation is not 
induced, cleaving only the fibrinopeptide A. Both Reptilase ${ }^{\circledR}$ time and thrombin time are complementary tests to evaluate coagulation disorders. Reptilase ${ }^{\circledR}$ is also used to detect antithrombin activity (Francischetti and Gil, 2019).

RVV-V (Pefakit ${ }^{\circledR}$ ) is a $27 \mathrm{kDa}$ factor $\mathrm{V}$-activating serine protease from the Russel's viper (Daboia russelii) venom, used to identify factor V levels in plasma (Tokunaga et al., 1988). It is widely used in assays for the diagnosis of resistance to activated protein $\mathrm{C}$, which does not cleaves factors $\mathrm{Va}$ and VIIIa (Francischetti and Gil, 2019).

RVV-X (Stypven ${ }^{\circledR}$ ) is a $120 \mathrm{kDa}$ factor $\mathrm{X}$-activating metalloprotease from $D$. russelii venom that converts factor $\mathrm{X}$ quantitatively into factor Xa (Tans and Rosing, 2001; Morita, 2005). This toxin is dependent of $\mathrm{Ca}^{2+}$, factor $\mathrm{V}$, phospholipids and prothrombin (Francischetti and Gil, 2019).

Ecarin, from E. carinatus venom, is a $55 \mathrm{kDa}$ metalloprotease able to activate prothrombin and detect its abnormal types (Morita et al., 1976; Weinger et al., 1980; Braud et al., 2000). Contrary to RVV-X, ecarin is independent of factor $\mathrm{V}$, phospholipids or $\mathrm{Ca}^{2+}$, detecting thrombin with chromogenic substrates (Ecarin chromogenic assay-ECA) or in a clotting assay (Ecarin clotting time-ECT) (Francischetti and Gil, 2019).

RVV-V, RVV-X, and ecarin are used to the diagnosis of lupus anticoagulant (Francischetti and Gil, 2019), one of the clinical manifestations of Antiphospholipid Syndrome, characterized by the presence of antiphospholipid antibodies (Favaloro and Wong, 2014).

Other snake venom toxins used as diagnostic tools include Botrocetin ${ }^{\circledR}$ and Protac ${ }^{\circledR}$. Venom coagglutinin (Botrocetin ${ }^{\circledR}$ ) isolated from $B$. jararaca venom is a $22 \mathrm{kDa}$ C-type lectin-like protein that aggregates platelets by increasing the affinity between the receptor GPIb $\alpha$ and von Willebrand factor (Brinkhous et al., 1983; Beeton, 2013), independent of von Willebrand factor molecule size (Francischetti and Gil, 2019).

ACC-C (Protac ${ }^{\circledR}$ ) from A. contortrix contortrix venom is a plasma protein $\mathrm{C}$-activating serine protease used to quantify protein S and C levels (Stocker et al., 1988) with chromogenic substrates or by prolongation of the activated partial thromboplastin time (aPTT). These protein levels are used to investigate the cause of a blood clot (thromboembolism), linked to deep vein thrombosis or pulmonary embolism. AAC-C activity is not compromised by the inhibitor of protein $\mathrm{C}$ from plasma (Francischetti and Gil, 2019).

\section{Cosmeceuticals}

The cosmeceutical field is a profitable venture. For example, the anti-wrinkling effect of the botulinum toxin (Botox ${ }^{\circledR}$ ), a toxin isolated from Clostridium botulinum bacteria, accounts for striking global sales of about $\$ 3$ billion per year (Clark et al., 2019). Among the biologically active compounds from animal venoms showing cosmeceuticals applications, we can cite the use of bee venom-containing cosmetics on facial wrinkles in human skin (Han et al., 2015), and the inhibitory activity of melanogenesis of Argiotoxine-636 (ArgTX-636), a polyamine isolated from Argiope lobata spider venom (Verdoni et al., 2016), including a deposited patent (US10064814B2) for skin whitening/ depigmenting (Mabrouk et al., 2018). Another example is the synthetic tripeptide [dipeptide diaminobutyroyl benzylamide diacetate (H- $\beta$-Ala-Pro-Dab-NHBzl x 2 AcOH)], commercialized as the cosmeceutical SYN ${ }^{\circledR}$-AKE (Pentapharm). It mimics the activity of waglerin 1 , a 22 -amino acid peptide from Tropidolaemus wagleri snake venom, and reduces wrinkles by inhibiting muscle contractions (Zhang and Falla, 2009).

\section{Venom Therapies}

Bee venom therapy is an ancient therapy which uses this toxin arsenal as a cream, liniment, ointment, injection, acupuncture, or directly via stings of live bees to treat several disorders (Ali, 2012). Those treatments rely on the fact that bee venom is composed of a wide range of components, such as biogenic amines, enzymes (mostly $\mathrm{PLA}_{2} \mathrm{~s}$ ), basic peptides, and nonenzyme proteins (mainly melittin and apamin) (Santos et al., 2011). Bee venom acupuncture corresponds to the most common used method, especially in the Koreas, and can be employed as an alternative treatment to pain, rheumatoid arthritis, osteoarthritis, and multiple sclerosis. The treatment consists of using bee venom in the relevant sites according to the disease or acupuncture points (Lee et al., 2014). A phase II randomized study to evaluate the effects of bee venom acupuncture in 68 participants with adhesive capsulitis (frozen shoulder) (NCT01526031) and another one in 60 patients with chronic cervicalgia (NCT01922466) were completed in 2012 and 2015, respectively.

Bee venom designated as apitoxin $\left(\right.$ Apitox $^{\circledR}$ ) has been marketed by Apimeds, Inc. for osteoarthritis in South Korea since 2016. A phase III randomized study (NCT01112722) in 363 patients with diagnosed osteoarthritis of the knee was completed in 2016 and a phase III randomized study (NCT03710655) for multiple sclerosis is not yet recruiting patients (last update 2018). Apitox ${ }^{\circledR}$ diminishes the pain and swelling associated with rheumatoid arthritis, tendinitis, bursitis, and multiple sclerosis (Bastos et al., 2011; Moreno and Giralt, 2015).

Another therapy for medicinal purposes is the hirudotherapy (medicinal leech therapy), approved in 2004 by the FDA. Since the beginning of civilization, leeches have been used for therapeutic purposes (Koh and Kini, 2008; Abdualkader et al., 2013). They are hematophagous animals that possess about 100 biologically active compounds in their saliva, especially the anticoagulants, but also components with anti-inflammatory, bacteriostatic, and analgesic properties (Singh, 2010). Many of the compounds responsible for those activities have already been identified (Sig et al., 2017), such as hirudin, kallikrein inhibitors, calin, hyaluronidase, collagenase, histamine-like substances, and antimicrobial peptides (e. g. theromacin, theromyzin, peptide B and lumbricin) (Cooper and Mologne, 2017). H. medicinalis, also known as the healing leech, is the main species used in the therapy (Abdualkader et al., 2013). The hirudotherapy has been shown to produce statistically significant improvement of arthritic conditions (Cooper and Mologne, 2017) and has also been applied in cardiovascular diseases, reconstructive and microsurgery, cancer and metastasis, diabetes mellitus and its complications, infectious diseases, arthritis, and as analgesic 
(Singh, 2010; Abdualkader et al., 2013). For an extensive review regarding these venom therapies, please see (Mumcuoglu, 2014; Jagua-Gualdrón et al., 2020).

The hirudotherapy and all the toxin-based drugs approved by the FDA are chronologically shown in the next timeline (Figure 1).

\section{ANIMAL TOXIN-BASED DRUG DEVELOPMENT CHALLENGES}

Animal toxins are most often useful as pharmacological tools for target validation. However, in section Achievements With Animal Toxin-Based Molecules it was shown that they have also been successfully used as therapeutic agents.

Although there are examples of success, there is a gap between the number of compounds with interesting pharmacological properties obtained from animal poisons and venoms and those that are approved. Drug development programs may be discontinued due to several factors, like intellectual property disputes, changes in the program leadership, lack of funding, among other business decisions. The lack of publications regarding important data, during the different stages of their development, also contributes to several program discontinuations. While we sought to retrieve this information from the scientific literature, this fact impairs most of the process, concealing most of the key events.

The subsections Challenges Regarding Basic Research to Challenges Regarding Clinical Trials will address the challenges related to basic research, preclinical evaluation and clinical trials during the development of animal toxin-based drugs. However, many challenges faced during these stages are not available in the scientific literature, since much of this information is under intellectual property law for compounds that are still being developed or for which the development stopped because of internal issues.

\section{Challenges Regarding Basic Research}

One of the bottlenecks when studying toxins from small or rare venomous species, such as scorpions and spiders, is the hardship in obtaining large amounts of venom and purified toxins. For example, the venom glands from Cupiennius salei spider contain only $10 \mu \mathrm{l}$ of venom, and the venom regeneration in milked animals requires from 8 to 16 days (Wigger et al., 2002). On the other hand, the snake Lachesis muta muta is able of injecting large venom amounts (milliliters of venom yielding 200-400 mg of toxins) (Stransky et al., 2018). The higher amount of collected snake venom is one of the reasons that may explain why most of the approved animal toxins-based drugs come from these animals.

Mucus-rich samples, such as toad and frog poisons, is also another issue, which may hinder the use of omic approaches (Shibao et al., 2018). In this context, studies comprising animal toxins are not a simple task since many challenges must be addressed. The small amount obtained from different poisonous and venomous animals, together with the nature of the venom/ poison allied with the difficulty in isolating specific toxins, are the main limitations faced during basic research. Overcoming these limitations is thoroughly discussed in section Filling the Gap Between the Drug Discovery and Its CommercializationFuture Trends.

\section{Challenges Regarding Preclinical Evaluation}

Problems in the development of toxin-based drugs encompass selectivity, mechanism of action, formulation, stability, and production cost (Zhang and Falla, 2009). Besides the modern approaches using omic techniques, molecular biology, bioconjugation, and nanomaterials in animal venom research, venom components do not always meet all the requirements for a potential therapeutic application. Drug metabolism and pharmacokinetics properties of animal toxins, for instance, are key factors that need to be carefully optimized (Kovalainen et al., 2015).

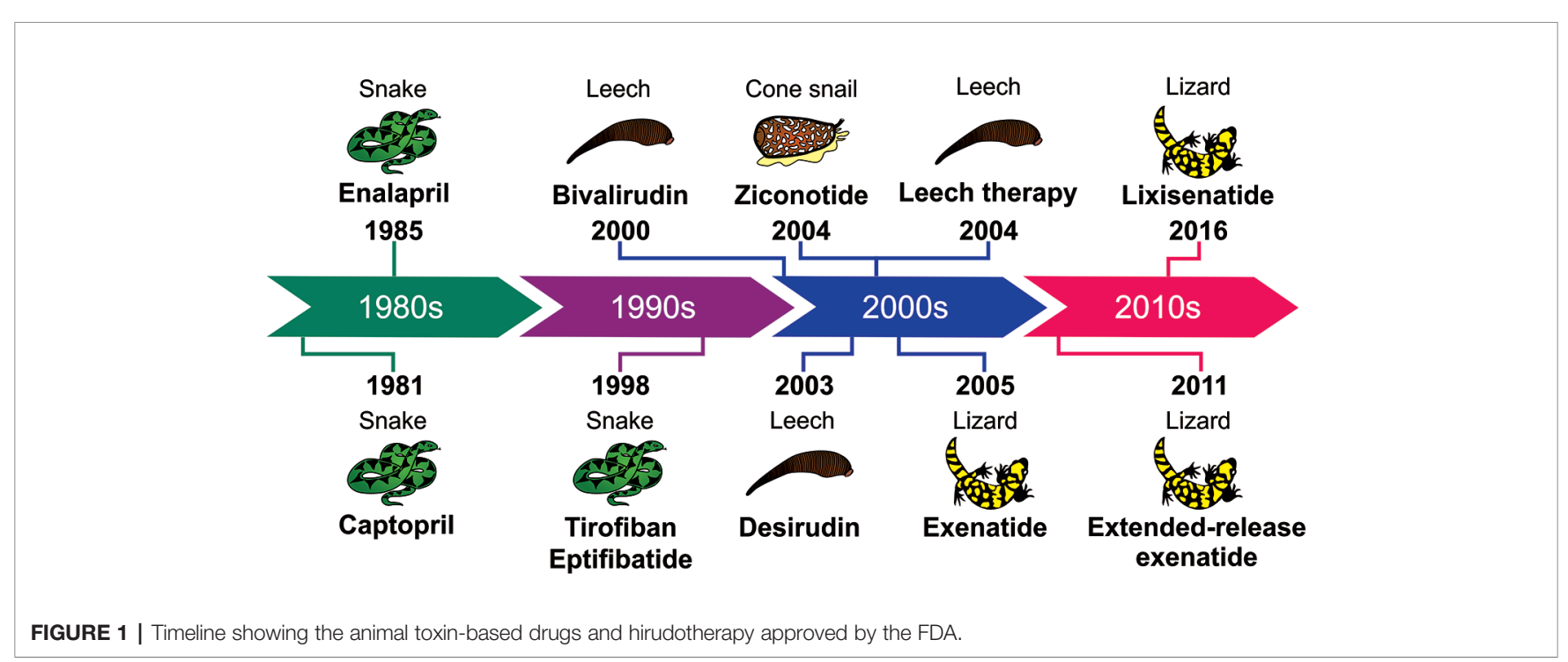


In this regard, after overcoming the challenges imposed during the basic research, like obtaining enough amount of the toxin, it becomes necessary to stand up against some pitfalls faced during preclinical evaluation. Some compounds lack the ability of crossing pivotal barriers in the organism, including the blood-brain barrier, which may interfere in their delivery. Additionally, the susceptibility to blood proteases, as well as their immunogenicity, which are directly linked to biopharmaceutical degradation in vivo, are also important factors to be considered. Due to the relatively large size and other specific physicochemical properties, parenteral administration is currently the most used delivery route for approved venom-based drugs (Table 1) (Ibraheem et al., 2014; Duskey et al., 2017).

Considering all the challenges at this phase, preclinical studies are usually costly and lengthy, since they must attend all the requirements stated by the regulatory agencies throughout the world. In this respect, regulatory issues, together with problems related to lack of funding, and manufacturing problems, have been a hindrance for academics pursuing to advance their drug candidates into the clinical trials.

\section{Challenges Regarding Clinical Trials}

Randomized clinical trials are the gold standard to evaluate specific drug-related issues such as the efficacy and, to a lesser extent, the safety of new medicines before marketing approval. But these studies are not often able to evaluate special populations, such as children, pregnant women, and the elderly (Trifiro et al., 2019). To overcome these limitations, studies using electronic healthcare records (EHRs) of post-marketing comparative drug safety may complement traditional spontaneous reporting systems to predict which drugs require further epidemiological investigation. For instance, a multi-country healthcare database network identified new signals of potentially drug-induced acute liver injury in children using EHRs (Ferrajolo et al., 2014). A method of enhancing effectiveness of therapeutic agents using taxane nanoparticle co-administered with the therapeutic agent has been recently patented (US10660965B2).

On this point, the obstacles faced during the process of approving a new drug are harder to overcome than just improving its drugability, with two mainly issues contributing at this stage. First, new therapeutic drugs must achieve very high standards to be accepted, since they may have to compete with older and well-known drugs on the market, which may be more effective and cheaper, in most cases (because of the expired patent, for instance) (Scannell et al., 2012). Another problem is when the role of the toxin's target on the disease state is less relevant than previously thought for the manifestation of a particular disease, resulting in low efficacy. Even more, unexpected and unwanted effects could be observed in vivo if the target is expressed at different cells or if the toxin binds promiscuously to other targets (Scannell et al., 2012; Harvey, 2014; Vetter et al., 2017). In this context, adverse effects, lack of efficacy and dose-limiting toxicity are responsible for the interruption of many clinical trials (Harvey, 2014; Lewis, 2015).

\section{LEARNING FROM DISCONTINUED TOXIN- BASED DRUGS}

Most cases of drugs withdrawn from the market (voluntarily or prohibited by regulatory agencies) are related to different events, ranging from safety issues, like serious side effects, to several nonsafety issues, encompassing those related to the manufacturing process, regulatory or business issues, or lack of efficacy. The foreseen toxicity of some toxin-based drugs may not be completely avoided, impairing the process at different stages of drug development. Therefore, understanding the mechanisms of toxicity is of utmost importance as an attempt to prevent postmarketing withdrawals (Siramshetty et al., 2016).

A mimetic peptide isolated from Naja spp. cobra venom, ximelagatran $\left(\right.$ Exanta $^{\circledR},{ }^{\circledR}$ AstraZeneca), was discontinued in 2006, due to hepatotoxic potential (King, 2011). This prodrug anticoagulant agent, orally administered, had been approved in Europe and South America for thrombin inhibition (Eriksson et al., 2003; Koh et al., 2006; Fox and Serrano, 2007; King, 2011). While Ximelagatran was mostly well tolerated in specific trial populations, a small proportion of the treated patients developed elevated liver enzyme levels, during phase II of clinical trials, which caused the FDA to reject its approval.

A phase III study of agkisacutacin (also known as hemocoagulase) in perioperative bleeding (Wei et al., 2010) was ceased due to anaphylactic reactions (Xu et al., 2016). The enzyme, which acts on fibrinogen and fibrin, is a heterodimeric serine protease from Deinagkistrodon acutus venom whose monomers A and B are comprised of 123 and 129 amino acid residues, respectively, linked by a disulfide bond (Wei et al., 2010). On the other hand, a phase IV randomized study (NCT03270735) to evaluate the efficacy and safety of hemocoagulase injection in the treatment of moderate to severe hemoptysis is recruiting patients since 2017. However, updated information regarding the evolution of this study could not be retrieved.

Pexiganan, also known as MSI-78 (a 22-residue linear peptide analogue of magainin-2), isolated from the skin of Xenopus laevis frog, is an antimicrobial peptide with therapeutic potential in treatment of infected foot ulcers in diabetic patients. The molecule presents in vitro activity against both Gram-positive and Gram-negative bacteria. The company Dipexium Pharmaceuticals, Inc. patented a $0.8 \%$ pexiganan acetate cream (Locilex ${ }^{\circledR}$ or Cytolex) but, in 1999, FDA denied the approval of this medicine arguing that its efficacy was not proven superior to that of the conventional treatment in any of the clinical trials (Ladram and Nicolas, 2016; Gomes et al., 2017).

Following the approval of ziconotide, other conotoxins, such as leconotide and Xen2174, were synthesized, studied and advanced to clinical trials. Leconotide (AM336 or $\omega$-conotoxin CVID from Conus catus) caused side effects when intrathecally administered and would be intravenously evaluated, but the developer company went bankrupt (Harvey, 2014). Xen2174 ( $\chi$-CTX MrIA from C. marmoreus) progressed to Phase IIb trial (Lewis, 2015), but it showed dose-limiting toxicity in pharmacodynamics and 
cerebrospinal fluid pharmacokinetics assays. Thus, it is unlikely that this conotoxin can be used for the treatment of acute pain in humans (Okkerse et al., 2017).

Alfimeprase, a recombinant zinc metalloprotease fibrolase from Agkistrodon contortrix with 203 residues and three disulfide bonds, cleaves the $\mathrm{A} \alpha$ - and $\mathrm{B} \beta$-chains of fibrin, releasing fibrinopeptides $\mathrm{A}$ and B, respectively (King, 2011; Koh and Kini, 2012; Swenson and Markland, 2013). This molecule reached phase III of clinical trials in catheter occlusion and stroke; however, it was discontinued due to the lack of effectiveness (Shah and Scher, 2007; Markland and Swenson, 2010).

Among the several reasons for the interruption of many drug development programs are also intellectual property conflicts, lack of funding, business issues or changes in development leadership. In the case of lepirudin (Refludan ${ }^{\circledR}$ ), for instance, its marketing was discontinued by Bayer in 2012 because the third-party manufacturer of the product had permanently ceased production of the drug (Bayer Healthcare, 2012). But the reasons that led to the manufacturing interruption have not been published, which prevents the proposal of solutions. Lepirudin is a recombinant peptide similar to hirudin, with an isoleucine instead of a leucine at N-terminal region and also lacking a sulfate group at Tyr63. It was marketed for prophylaxis or treatment of thrombosis complicating heparin-induced thrombocytopenia (Lee and Ansell, 2011).

The process of looking for information on drug removals from the market or haltered developments is a difficult task, since some of them are not available for several reasons aforementioned, and the data retrieved from public databases are significantly limited. In other words, factors that have not been published could have contributed to the discontinuation of the program.

\section{PROMISING ANIMAL TOXINS IN PRECLINICAL STAGE AND CLINICAL TRIALS}

The database search for toxin-based drugs on clinical trials is challenging. One needs to know the acronym or the abbreviation of the desired active ingredient, since sometimes neither the species nor the generic name is cited to allow a broad search. Furthermore, most of the information on these drugs is confidential and thus not available in the public domain. Another problem is that a lot of available data for some drugs have not been updated for several years, which makes it difficult to find accurate details.

Clinical development is a lengthy and costly process that includes phases I to III of clinical trials (previous regulatory review and approval) and phase IV (post-marketing surveillance) (Chow and Chang, 2008). Phase I recruits healthy volunteers to assess primarily pharmacokinetics, safety and tolerability; phase II evaluates a cohort of patients with the target disease to establish efficacy and dose-response relationship, and the largescale phase III studies confirm safety and efficacy (Tamimi and Ellis, 2009). Phase IV clinical development focus on the safety rather than efficacy (Chow and Chang, 2008).
The following subsections will address the clinical trial status of some toxin-based drugs from different animal species and additional information about these drugs is available in Table 2.

\section{Amphibians}

Chansu, the dried toad venom secreted by the skin glands of $B u f_{0}$ gargarizans (previously B. bufo gargarizans) or Duttaphrynus melanostictus (previously B. melanostictus), has been used in the Traditional Chinese Medicine for more than 1000 years (Qi et al., 2011). Bufalin, the major digoxin-like immunoreactive component of Chansu, is a cardiotonic glycoside (bufadienolide) present in toad poisons and has demonstrated anticancer activities in several preclinical studies (Miao et al., 2013). Cinobufagin and resibufogenin are also bufadienolides present in Chansu, capable of inhibiting cancer cells growth in vitro (Xie et al., 2012; Li et al., 2013).

Huachansu (also known as cinobufacini) is a sterilized aqueous extract of Chansu, designed for intravenous injection, and has been widely used in oncological clinics in China to treat patients with several types of cancer, being approved by the NMPA (formerly China FDA) (Qi et al., 2011; Liu et al., 2015). The major biologically active components present in huachansu are steroidal cardiac glycosides, such as bufalin, resibufogenin, cinobufagin, cinobufotalin, marinobufagin (also known as marinobufagenin) and bufotalin, and indole alkaloids, like bufotenine, bufotenidine, cinobufotenine, and serotonin ( $\mathrm{Su}$ et al., 2003).

During a phase I clinical study, huachansu was tolerable even at doses 6 times higher than those normally administered, and could slow disease progression in some cancer patients, with no observed significant cardiac toxicity (Meng et al., 2009).

The efficacy and safety of gemcitabine-oxaliplatin (Gemox) combined with huachansu chemotherapy is an effective and welltolerated regimen for advanced and metastatic gallbladder carcinoma (Qin et al., 2008). Another study showed that huachansu combined with chemotherapy reduced the occurrence of gastrointestinal side effects and leukocytopenia in patients with advanced gastric cancer (Xie et al., 2013).

Many in vitro studies demonstrating anticancer properties of huachansu justify its continued evaluation in clinical trials. Phases II and III studies started recruiting participants, in 2016, to evaluate if cinobufacini tablets have synergistic effect in the treatment of diffuse large B cell lymphoma, the most common subtype of non-Hodgkin lymphoma. The estimated date of conclusion of the study is December 2021 (NCT02871869).

Bombesin is a peptide composed of 14 amino acids (EQRLGNQWAVGHLM-NH $\mathrm{N}_{2}$ ), isolated from the poisonous skin of the frog Bombina bombina, that shows high affinity for gastrin-releasing peptide-receptors (Tornesello et al., 2017; Utkin, 2017). Overexpression of members of this receptor family has been documented in several human neoplasms, such as prostate cancer, breast cancer, and small cell lung cancer. In this way, these receptors represent a molecular target for radiolabeled bombesin analogues as diagnostic or radiotherapeutic applications in these tumors (Schwartsmann et al., 2006; Wieser et al., 2014). Gallium-68 (68Ga)-DOTAbombesin completed phase II in 2017 with 10 patients presenting 
TABLE 2 | Toxin-based drugs in clinical trials.

\begin{tabular}{|c|c|c|c|c|c|c|c|}
\hline $\begin{array}{l}\text { Molecule (NCT } \\
\text { number) }\end{array}$ & $\begin{array}{l}\text { Species origin } \\
\text { of venom toxin }\end{array}$ & Production & Formulation & Mechanism of action & Use & Status(last update) & Reference \\
\hline $\begin{array}{l}\text { ACV-1 ( } \alpha-V c 1.1) \\
\text { - Discontinued }^{(1)}\end{array}$ & Conus victoriae & Synthetic & S.c. injection & $\begin{array}{l}\text { Activation of } \mathrm{GABA}_{\mathrm{B}} \\
\text { receptors }\end{array}$ & $\begin{array}{l}\text { Neuropathic } \\
\text { pain }\end{array}$ & $\begin{array}{l}\text { Phase II-discontinued } \\
\text { (lack of efficacy) }\end{array}$ & $\begin{array}{l}\text { (Clark et al., } \\
\text { 2010; King, } \\
\text { 2011) }\end{array}$ \\
\hline $\begin{array}{l}\text { Agkisacutacin, } \\
\text { Hemocoagulase, } \\
\text { Recothrom }^{\circledR} \\
\text { (NCT not } \\
\text { available; } \\
\text { NCT03270735) }\end{array}$ & $\begin{array}{l}\text { Deinagkistrodon } \\
\text { acutus }\end{array}$ & Recombinant & I.v. infusion (2U) & $\begin{array}{l}\text { Fibrinogen and fibrin } \\
\text { cleavage }\end{array}$ & $\begin{array}{l}\text { Perioperative } \\
\text { bleeding; } \\
\text { moderate to } \\
\text { severe } \\
\text { hemoptysis }\end{array}$ & $\begin{array}{l}\text { Phase III ceased } \\
\text { (2016); phase IV } \\
\text { recruiting (September } \\
\text { 1, 2017) }\end{array}$ & $\begin{array}{l}\text { (Wei et al., } \\
\text { 2010) }\end{array}$ \\
\hline $\begin{array}{l}\text { Alfimeprase - } \\
\text { Discontinued } \\
\text { (NCT00338585) }^{(2)}\end{array}$ & $\begin{array}{l}\text { Agkistrodon } \\
\text { contortrix } \\
\text { contortrix }\end{array}$ & Recombinant & $\begin{array}{l}\text { Parenteral } \\
\text { administration (up to } \\
0.5 \mathrm{mg} / \mathrm{kg} \text { was } \\
\text { tolerated) }\end{array}$ & $\begin{array}{l}\text { Cleaves } A \alpha \text {-chain of } \\
\text { fibrin and fibrinogen }\end{array}$ & $\begin{array}{l}\text { Catheter } \\
\text { occlusion and } \\
\text { stroke }\end{array}$ & $\begin{array}{l}\text { Phase III terminated } \\
\text { (based upon } \\
\text { preliminary safety and } \\
\text { efficacy results from a } \\
\text { similar study) (January } \\
\text { 15, 2008); }\end{array}$ & $\begin{array}{l}\text { (Swenson } \\
\text { et al., 2004; } \\
\text { Ouriel et al., } \\
\text { 2005) }\end{array}$ \\
\hline $\begin{array}{l}\text { Bombesin } \\
\text { (NCT02440308) }\end{array}$ & $\begin{array}{l}\text { Bombina } \\
\text { bombina }\end{array}$ & Synthetic & I.v. & $\begin{array}{l}\text { Attaches to prostate } \\
\text { tumor cells with specific } \\
\text { receptors on their } \\
\text { surfaces }\end{array}$ & $\begin{array}{l}\text { Imaging agent } \\
\text { for positron } \\
\text { emission } \\
\text { tomography/ } \\
\text { magnetic } \\
\text { resonance } \\
\text { imaging }\end{array}$ & $\begin{array}{l}\text { Phase II completed } \\
\text { (April 11, 2017) }\end{array}$ & $\begin{array}{l}\text { (US National } \\
\text { Library of } \\
\text { Medicine, } \\
\text { 2020) }\end{array}$ \\
\hline $\begin{array}{l}\text { Cenderitide, CD- } \\
\text { NP } \\
\text { (NCT00482937, } \\
\text { NCT02603614, } \\
\text { NCT02359227 } \\
\text { and } \\
\text { NCT02071602) }\end{array}$ & $\begin{array}{l}\text { Dendroaspis } \\
\text { angusticeps }\end{array}$ & $\begin{array}{l}\text { Chimeric } \\
\text { natriuretic } \\
\text { peptide }\end{array}$ & $\begin{array}{l}\text { I.v. infusion (10, } 25,50 \text {, } \\
100,200 \text {, and } 300 \mathrm{ng} / \\
\mathrm{kg} / \mathrm{min} \text { over } 4 \mathrm{~h} \text { ) or } \\
\text { subcutaneous infusion } \\
(0.5,1.0,2.0 \text {, and } 3.0 \\
\mathrm{ng} / \mathrm{kg} / \mathrm{min}) \text { or IV infusion } \\
(5 \text { and } 10 \mathrm{ng} / \mathrm{kg} / \mathrm{min} \\
\text { over } 72 \mathrm{~h})\end{array}$ & $\begin{array}{l}\text { Connection to } \\
\text { natriuretic peptide } \\
\text { receptor }\end{array}$ & $\begin{array}{l}\text { Congestive } \\
\text { cardiac failure, } \\
\text { heart failure and } \\
\text { myocardial } \\
\text { infarction }\end{array}$ & $\begin{array}{l}\text { Phase I completed } \\
\text { (June 6, 2007; } \\
\text { February 11, } 2020 \text { and } \\
\text { January 4, 2019) }\end{array}$ & $\begin{array}{l}\text { (Lee et al., } \\
\text { 2009) }\end{array}$ \\
\hline $\begin{array}{l}\text { Cinobufacini } \\
\text { (Buformin }^{\circledR} \text { ) } \\
\text { (NCT02871869) }\end{array}$ & $\begin{array}{l}\text { Bufo gargarizans } \\
\text { or Duttaphrynus } \\
\text { melanostictus }\end{array}$ & $\begin{array}{l}\text { Sterilized water } \\
\text { extract of dried } \\
\text { toad skin } \\
\text { (Chansu) }\end{array}$ & $\begin{array}{l}0.3 \mathrm{~g} \text { per tablet, three } \\
\text { tablets per time }\end{array}$ & $\begin{array}{l}\text { Induction of apoptosis; } \\
\text { inhibition of cancer cells }\end{array}$ & $\begin{array}{l}\text { Several types of } \\
\text { cancer }\end{array}$ & $\begin{array}{l}\text { Phase II/III recruiting } \\
\text { (July } 17,2017 \text { ) }\end{array}$ & $\begin{array}{l}\text { (US National } \\
\text { Library of } \\
\text { Medicine, } \\
\text { 2020) }\end{array}$ \\
\hline $\begin{array}{l}\text { Conantokin-G } \\
\text { (CGX-1007) - }^{(1)} \\
\text { Discontinued }^{(1)}\end{array}$ & $\begin{array}{l}\text { Conus } \\
\text { geographus }\end{array}$ & Synthetic & Intrathecal & $\begin{array}{l}\text { NMDA receptor } \\
\text { antagonist }\end{array}$ & $\begin{array}{l}\text { Intractable } \\
\text { epilepsy }\end{array}$ & $\begin{array}{l}\text { Phase I-discontinued } \\
\text { (the developer } \\
\text { company went } \\
\text { bankrupt) }\end{array}$ & $\begin{array}{l}\text { (Han et al., } \\
\text { 2008; King, } \\
\text { 2011) }\end{array}$ \\
\hline $\begin{array}{l}\text { Contulakin-G } \\
\text { (CGX-1160) - } \\
\text { Discontinued }^{(1)}\end{array}$ & $\begin{array}{l}\text { Conus } \\
\text { geographus }\end{array}$ & Synthetic & Intrathecal & $\begin{array}{l}\text { Neurotensin receptor } \\
\text { agonist }\end{array}$ & $\begin{array}{l}\text { Neuropathic } \\
\text { pain }\end{array}$ & $\begin{array}{l}\text { Phase II-discontinued } \\
\text { (the developer } \\
\text { company went } \\
\text { bankrupt) }\end{array}$ & $\begin{array}{l}\text { (Han et al., } \\
\text { 2008; King, } \\
\text { 2011) }\end{array}$ \\
\hline $\begin{array}{l}\text { Dalazatide, ShK- } \\
186, \\
\text { Stichodactyla }\end{array}$ & $\begin{array}{l}\text { Stichodactyla } \\
\text { helianthus } \\
\text { (Sun sea } \\
\text { anemone) }\end{array}$ & Synthetic & $\begin{array}{l}\text { S.c. injection twice per } \\
\text { week for a total of nine } \\
\text { doses }\end{array}$ & $\begin{array}{l}\mathrm{Kv} 1.3 \text { channel } \\
\text { antagonist }\end{array}$ & $\begin{array}{l}\text { Autoimmune } \\
\text { diseases } \\
\text { (psoriatic } \\
\text { arthritis, multiple }\end{array}$ & $\begin{array}{l}\text { Phase I completed } \\
\text { (May 6, 2015) }\end{array}$ & $\begin{array}{l}\text { (US National } \\
\text { Library of } \\
\text { Medicine, } \\
\text { 2020) }\end{array}$ \\
\hline
\end{tabular}


TABLE 2 | Continued

\begin{tabular}{|c|c|c|c|c|c|c|c|}
\hline $\begin{array}{l}\text { Molecule (NCT } \\
\text { number) }\end{array}$ & $\begin{array}{l}\text { Species origin } \\
\text { of venom toxin }\end{array}$ & Production & Formulation & Mechanism of action & Use & Status(last update) & Reference \\
\hline $\begin{array}{l}\text { toxin ShK } \\
\text { (NCT02435342) (1) }\end{array}$ & & & & & $\begin{array}{l}\text { sclerosis, lupus, } \\
\text { rheumatoid } \\
\text { arthritis, etc.) }\end{array}$ & & \\
\hline $\begin{array}{l}\text { Desmoteplase } \\
\text { (NCT00790920 } \\
\text { and } \\
\text { NCT00111852) (2) }\end{array}$ & $\begin{array}{l}\text { Common } \\
\text { vampire bat } \\
\text { (Desmodus } \\
\text { rotundus) }\end{array}$ & Recombinant & $\begin{array}{l}\text { I.v. single bolus ( } 90 \text { or } \\
125 \mu \mathrm{g} / \mathrm{kg} \text { of body } \\
\text { weight) }\end{array}$ & $\begin{array}{l}\text { Plasminogen activator } \\
\text { a1 with high fibrin } \\
\text { specificity }\end{array}$ & $\begin{array}{l}\text { Acute ischemic } \\
\text { stroke }\end{array}$ & $\begin{array}{l}\text { Phase III completed } \\
\text { (September 18, 2015 } \\
\text { and March 20, 2012) }\end{array}$ & $\begin{array}{l}\text { (US National } \\
\text { Library of } \\
\text { Medicine, } \\
\text { 2020) }\end{array}$ \\
\hline $\begin{array}{l}\text { Leconotide } \\
\text { (AM336 or } \omega \text { - } \\
\text { conotoxin CVID) } \\
\text { - Discontinued }\end{array}$ & Conus catus & Synthetic & 3-6 $\mu \mathrm{g} / \mathrm{h}$ (intrathecal) & $\begin{array}{l}\text { Selective blocker of } \\
\text { Cav2.2 channel }\end{array}$ & $\begin{array}{l}\text { Neuropathic } \\
\text { pain }\end{array}$ & $\begin{array}{l}\text { Phase } 1 / \text { /la- } \\
\text { discontinued (the } \\
\text { developer company } \\
\text { went bankrupt) }\end{array}$ & $\begin{array}{l}\text { (Kolosov } \\
\text { et al., 2010; } \\
\text { King, 2011; } \\
\text { Harvey, 2014) }\end{array}$ \\
\hline $\begin{array}{l}\text { RPI-78M } \\
\left.\text { (Receptin }^{\circledR}\right) \text { (NCT } \\
\text { not avaiable) }^{(3)}\end{array}$ & Naja kaouthia & $\begin{array}{l}\text { Detoxified or } \\
\text { chemically } \\
\text { modified }\end{array}$ & $\begin{array}{l}\text { Orally (with } \\
\text { benzalkonium chloride) }\end{array}$ & $\begin{array}{l}\text { Connetion to nicotinic } \\
\text { acetylcholine receptors } \\
\text { (nAChRs) }\end{array}$ & $\begin{array}{l}\text { Analgesic } \\
\text { applications and } \\
\text { multiple sclerosis }\end{array}$ & $\begin{array}{l}\text { Manufacturing for } \\
\text { clinical trials (October } \\
\text { 28, 2018) }\end{array}$ & $\begin{array}{l}\text { (King, 2011; } \\
\text { Drug } \\
\text { discovery and } \\
\text { development, } \\
\text { 2016; Adis } \\
\text { Insight, 2018; } \\
\text { Ojeda et al., } \\
\text { 2018) }\end{array}$ \\
\hline $\begin{array}{l}\text { Soricidin, SOR- } \\
\text { C13 } \\
\text { (NCT01578564 } \\
\text { and } \\
\text { NCT03784677) }{ }^{(1)}\end{array}$ & $\begin{array}{l}\text { Blarina } \\
\text { brevicauda } \\
\text { (Northern short- } \\
\text { tailed shrew) }\end{array}$ & Synthetic & $\begin{array}{l}\text { I.v. infusion (dose range } \\
\text { from } 1.375 \text { to } 6.12 \mathrm{mg} / \\
\mathrm{kg} \text { ) }\end{array}$ & $\begin{array}{l}\text { Inhibitor of the } \mathrm{Ca}^{2} \\
{ }^{+} \text {-selective transient } \\
\text { receptor potential } \\
\text { channel TRPV6 }\end{array}$ & $\begin{array}{l}\text { Ovarian (and } \\
\text { other) cancers }\end{array}$ & $\begin{array}{l}\text { Phase I completed } \\
\text { (June 23, 2016) and } \\
\text { recruiting (August 6, } \\
\text { 2019) }\end{array}$ & $\begin{array}{l}\text { (US National } \\
\text { Library of } \\
\text { Medicine, } \\
\text { 2020) }\end{array}$ \\
\hline $\begin{array}{l}\text { Tetrodotoxin } \\
\left(\text { (Tectin }^{\circledR} \text { ) }\right. \\
\text { (NCT01655823) }^{(4)}\end{array}$ & $\begin{array}{l}\text { Pufferfish, } \\
\text { marine animals } \\
\text { and } \\
\text { phylogenetically } \\
\text { unrelated } \\
\text { terrestrial } \\
\text { organisms }\end{array}$ & Synthetic & $\begin{array}{l}\text { Different injectable } \\
\text { dosages }(1 \mathrm{ml}) \text {, twice a } \\
\text { day for four consecutive } \\
\text { days }\end{array}$ & Sodium channel blocker & $\begin{array}{l}\text { Neuropathic } \\
\text { pain caused by } \\
\text { chemotherapy }\end{array}$ & $\begin{array}{l}\text { Phase II terminated } \\
\text { (decided to proceed to } \\
\text { Phase III) (October 30, } \\
\text { 2018) }\end{array}$ & $\begin{array}{l}\text { (US National } \\
\text { Library of } \\
\text { Medicine, } \\
\text { 2020) }\end{array}$ \\
\hline $\begin{array}{l}\text { Xen } 2174 \text { ( } \chi \text {-CTX } \\
\text { MrIA) - } \\
\text { Discontinued }{ }^{(1)}\end{array}$ & $\begin{array}{l}\text { Conus } \\
\text { marmoreus }\end{array}$ & Synthetic & Intrathecal & $\begin{array}{l}\text { Interacts with a large } \\
\text { hydrophobic pocket } \\
\text { within the } \\
\text { norepinephrine } \\
\text { transporter }\end{array}$ & $\begin{array}{l}\text { Postoperative } \\
\text { pain }\end{array}$ & $\begin{array}{l}\text { Phase Illb (2015)- } \\
\text { discontinued }\end{array}$ & $\begin{array}{l}\text { (Brust et al., } \\
\text { 2009; King, } \\
\text { 2011; Lewis, } \\
\text { 2015) }\end{array}$ \\
\hline $\begin{array}{l}\text { Ximelagatran } \\
\left(\text { Exanta }^{\circledR}\right) \text { - }\end{array}$ & Naja spp. & Synthetic & $36 \mathrm{mg}$ orally twice daily. & Direct thrombin inhibitor & $\begin{array}{l}\text { Prevention of } \\
\text { venous }\end{array}$ & $\begin{array}{l}\text { Phase III terminated } \\
\text { (November 15, 2010) } \\
\text { - withdrawn from the }\end{array}$ & $\begin{array}{l}\text { (Gulseth, } \\
\text { 2005; King, } \\
\text { 2011) }\end{array}$ \\
\hline
\end{tabular}


TABLE 2 | Continued

\begin{tabular}{|c|c|c|c|c|c|c|c|}
\hline $\begin{array}{l}\text { Molecule (NCT } \\
\text { number) }\end{array}$ & $\begin{array}{l}\text { Species origin } \\
\text { of venom toxin }\end{array}$ & Production & Formulation & Mechanism of action & Use & Status(last update) & Reference \\
\hline $\begin{array}{l}\text { Discontinued } \\
\text { (NCT00206089) }^{(4)}\end{array}$ & & & & & $\begin{array}{l}\text { thromboembolic } \\
\text { events }\end{array}$ & $\begin{array}{l}\text { market and clinical } \\
\text { development in } \\
\text { February } 2006 \text { in the } \\
\text { interest of patient } \\
\text { safety (hepatic toxicity) }\end{array}$ & \\
\hline
\end{tabular}

1), peptide; 2), enzyme; 3), non-enzyme protein; 4), organic molecule; i.v., intravenous; NCT, ClinicalTrials.gov identifier; s.c., subcutaneous.

prostate cancer. It is an imaging agent for positron emission tomography/magnetic resonance imaging and attaches to tumor cells with specific receptors on their surfaces (NCT02440308).

Different chemical modifications have been introduced in the synthetic bombesin to stabilize its structure, increase the binding affinity and to potentiate its agonist/antagonist properties (Cescato et al., 2008; Tornesello et al., 2017). A large variety of bombesin receptor ligands have been preclinically tested, most of which were bombesin agonists (Baratto et al., 2018). However, most of these ligands demonstrated high gastrointestinal uptake and limited metabolic stability in vivo, and can cause acute side effects (nausea, abdominal pain and emesis) when administered at higher doses (Accardo et al., 2016).

A synthetic bombesin/gastrin-releasing peptide-receptor antagonist (RC-3095) was able to produce long-lasting tumor regressions in murine and human tumor models in vitro and in vivo. Due to the occurrence of local toxicity at the injection site during a phase I trial in patients with advanced solid malignancies, a recommended dose of RC-3095 for Phase II trials could not be clearly established (Schwartsmann et al., 2006). Considering its mechanism of action and preclinical antitumor activity, further studies exploiting new formulations of RC-3095 for human use, such as slow-release preparations and analogues with a more favorable pharmacokinetics, are justified.

Epibatidine is an alkaloid extracted from the skin of the Ecuadorian frog Epipedobatus tricolor (poison-dart frog). This molecule binds to several nAChR subtypes, including $\alpha 7, \alpha 4 \beta 2$, and the neuromuscular $\alpha 1 \beta 1 \delta \gamma$ subtype. Antinociceptive efficacy of epibatidine is about 100 times more powerful than morphine, but it has induced adverse effects, revealing high toxicity to be used as a pain-relieving drug (Traynor, 1998; Salehi et al., 2019).

Many compounds based on the chemical structure of epibatidine have been developed and tested to become new, powerful pain-reducing drugs (Daly, 2004; Umana et al., 2013). An example is ABT-594 (tebanicline or ebanicline) (Salehi et al., 2019). ABT-594 is of particular interest once it is more powerful than morphine showing no morphine-associated side effects and only mild cardiovascular side effects (Fox and Serrano, 2007). Due to severe gastrointestinal side effects caused by this first analogue of epibatidine, it has not been included in pain therapies in humans (Salehi et al., 2019).

\section{Cone Snails}

Conotoxins, isolated from different species of cone snails (Conus ssp.), comprise a large family of small cysteine-rich peptides (1030 amino acid residues) organized in subfamilies according to their structure (cysteine framework) and their mechanism of action (Lewis et al., 2012; Ovsepian et al., 2019). Undoubtedly, omega-conotoxins represent the most notable and famous conotoxin subfamily, in which omega-MVIIA [ziconotide (Prialt $\left.{ }^{\circledR}\right)$, previously reported in the section Achievements With Animal Toxin-Based Molecules, belongs to.

KCP-400 (also known as RgIA4), derived from Vc1.1, the first toxin isolated from $C$. regius venom, is a novel non-opioid drug for the treatment of chronic pain. Vcl.1 is a highly potent toxin that targets $\alpha 9 \alpha 10 \mathrm{nAChR}$, blocking pain signaling at the site of nerve injury, producing analgesic, anti-inflammatory and neuroprotective effects (Romero et al., 2017). The preclinical safety and efficacy studies of KCP-400 had been conducted by Kineta Inc., which is currently developing the non-opioid KCP506 (Kineta Inc., 2020).

Because of their high potency and specificity, novel conotoxins can provide additional information on the pharmacology of ion channels, receptors, and transporters (Lewis et al., 2012; Gao et al., 2017).

\section{Hymenopterans}

The whole venom of bees (Alyostal ST Apis mellifera) completed a randomized phase II study, in 2014, to evaluate its efficacy and potential effects in 50 participants presenting motor symptoms of Parkinson's disease (NCT01341431). The administration of bee venom showed to be safe in non-allergic patients (Hartmann et al., 2016). Following the same direction of bee venom, the whole venom of ants has been employed in therapeutic use. For instance, the extracted material from venom sacs of Pseudomyrmex triplarinus could be helpful in relieving the pain caused by rheumatoid arthritis (WO1990003178A1, US4247540A).

The whole venom of wasps, bees and ants are also being used in venom immunotherapy (VIT), which represents a treatment to allergic patients preventing further sting-induced anaphylactic reactions (Kolaczek et al., 2017). Several clinical protocols and guidelines were published and generally consist of injections of small but gradually increasing doses of a specific venom (Bonifazi et al., 2005).

Despite those studies published employing hymenoptera whole venoms, little has been reported on the therapeutic applications of purified toxins. Thus far, the most explored hymenoptera venom components are melittin, apamin (both isolated from bees), and mastoparan (isolated from wasps) (Moreno and Giralt, 2015). All those three components arise as promising drug candidates for several conditions or therapeutic applications, such as antitumor agents (Gajski and 
Garaj-Vrhovac, 2013; de Azevedo et al., 2015), learning disabilities (Messier et al., 1991; Ikonen and Riekkinen, 1999), antimicrobial and antiviral activity (Vila-Farres et al., 2012; Sample et al., 2013), cell penetrating-peptides (Jones and Howl, 2012), among other applications.

Concerning melittin, a phase II study of ARC-520 in 79 participants with chronic hepatitis B virus (HBV) was terminated for regulatory and business reasons in 2019 (NCT02577029). The Dynamic Polyconjugate ${ }^{\circledR}$ technology, developed by Arrowhead Therapeutics, uses melittin as an endosomolytic agent to facilitate the delivery of siRNA conjugates to hepatocytes (US8313772; US8501930; US8618277; WO2013003520A1).

\section{Scorpions}

Chlorotoxin (CTx) is the only toxin from scorpion venoms undergoing clinical phase trials. The evidence of a venom molecule that interacts with chloride $\left(\mathrm{Cl}^{-}\right)$channels was firstly demonstrated by DeBin and Strichartz, which showed that Leiurus quinquestriatus quinquestriatus (the yellow scorpion from the Middle East, also known as death stalker) venom was able to block $\mathrm{Cl}^{-}$channels of reconstituted rat epithelia and embryonic rat brain (DeBin and Strichartz, 1991). CTx is a peptide with 36 amino acids presenting $4070 \mathrm{Da}, 4$ disulfide bonds and it is positively charged in $\mathrm{pH}$ 7. Moreover its structure was solved by nuclear magnetic resonance spectroscopy: threestranded antiparallel $\beta$-sheet packed against an $\alpha$-helix (Lippens et al., 1995). The synthetic CTx was also produced successfully (Ojeda et al., 2016).

CTx discovery was marked by a substantial rise of publications using this molecule for different applications, such as insecticide (DeBin et al., 1993), antiangiogenic (Jacoby et al., 2010), and tumor binding (Cohen-Inbar and Zaaroor, 2016). CTx has demonstrated the capability to bind to different targets including chloride channels, membrane type-2 matrix metalloprotease (MMP-2) and annexin A2 (Ojeda et al., 2016). However, a milestone in the CTx discovery was the production of fluorescent molecular probes such as the tumor paint (CTx conjugated with Cy5.5 or CTx : Cy5.5). This bioconjugate can detect cancer foci and metastases from malignant glioma, sarcoma medulloblastoma and prostate and intestinal cancers using mouse models. The specific identification by this fluorescent molecular beacon (CTx : Cy5.5) increases the precision of surgical resection (image guidance) and improves patient prognosis (Veiseh et al., 2007). CTx:800CW (an infrared dye conjugate) was also produced; however, it has failed since the integrity of the blood-brain barrier was compromised even in the early stages of medulloblastoma tumor (Kovar et al., 2013).

Tozuleristide (BLZ-100), a CTx indocyanine green conjugate, demonstrated to bind to tumor cells while sparing healthy tissues (Butte et al., 2014). Phase I studies of BLZ-100 in 17 patients with glioma undergoing surgery were finished in 2016 (NCT02234297). The 131-I-TM-601 is the recombinant version of chlorotoxin (TM601) radioconjugated with iodine 131 (Hockaday et al., 2005; Kesavan et al., 2010). It has been tested against different cancers (breast cancer, non-small cell lung cancer, melanoma, colorectal cancer, pancreatic cancer, prostate adenocarcinoma, glioma primary and solid tumors). The Phase I with 60 patients presenting recurrent or refractory somatic and/or cerebral metastatic solid tumors was completed in 2009 (NCT00379132). Regarding intellectual property, many patents applications can be detected relating to CTx variants, bioconjugates and methods for use, with an extensive list of records (e.g. WO2011142858A2; WO20006115633A2; US20030021810A1; US20160096869A1; US20080260639A1).

Although solely CTx reached clinical phase so far, other scorpion toxins have demonstrated therapeutic potential. For instance, the scorpion venom active polypeptide (SVAP) from Mesobuthus martensii (formerly B. martensii) has completed preclinical phase as a potential antithrombotic peptide. The results demonstrated that SVAP $(0.125,0.25,0.5 \mathrm{mg} / \mathrm{ml})$ inhibited rabbit platelet aggregation in vitro. Moreover, this peptide $(0.32$ and $0.64 \mathrm{mg} / \mathrm{kg}$, intravenous administration) prolonged the occlusion time of carotid artery thrombosis in rats. Thus, SVAP may be considered an interesting molecule to be used in the treatment of cardiocerebral vascular diseases (Song et al., 2005).

Cancer treatment is also explored with other scorpion toxins. Besides CTx, BmKCT, a CTx-like molecule from M. martensii venom, reversibly inhibits chloride currents of glioma cells (Yang et al., 2005). BmkTa, also a CTx-like from M. martensii venom, is able to abolish the human glioma cells growth in a dose-dependent manner, with an $\mathrm{IC}_{50}$ of approximately $0.28 \mu \mathrm{M}$ (Fu et al., 2007). Although some peptides must be highlighted (AmmTx3, BmTx3, Bekm-1, BmHyA, and IbTx), the list of scorpion toxins with antiproliferative activities is extensive (Das Gupta et al., 2007; Fu et al., 2012; Ding et al., 2014; Ortiz et al., 2015).

Scorpion toxins blocking potassium channels have also been widely investigated. In particular, those inhibiting $\mathrm{K}_{\mathrm{v}} 1.3$ currents are considered potential bioactive molecules to treat autoimmune diseases (Zhao et al., 2015). To the best of our knowledge, there are 81 scorpion toxins with positive results in inhibiting $\mathrm{K}_{\mathrm{v}} 1.3$ (Oliveira et al., 2019). Nevertheless, only eight of them present in vivo assays (i.e. most of them were studied using solely in vitro electrophysiological experiments). 1) HsTX1 from Heterometrus spinifer venom demonstrated to reduce inflammation in an active delayed-type hypersensitivity model and in the pristane-induced arthritis using rat models (Tanner et al., 2017). 2) ImKTX88 from Isometrus maculatus venom ameliorates pathological severity in rat experimental autoimmune encephalomyelitis (Huang et al., 2017). 3) Kaliotoxin (Ktx) from Androctonus mauretanicus mauretanicus venom showed the ability of preventing bone loss through a receptor activator of NF- $\kappa B$ ligand (RANKL)-dependent osteoclastogenesis mechanism, using rat periodontal disease model. Thus, Ktx has been tested to treat periodontal disease and rheumatoid arthritis (Valverde et al., 2004). 4) Margatoxin (MgTX) from Centruroides margaritatus venom caused a reduction of tumor volume into a xenograft model using nude mice by blocking $\mathrm{K}_{\mathrm{v}} 1.3$ channels, and it is being considered as a novel therapeutic target for lung adenocarcinoma therapy (Jang et al., 2011). 5) OSK1 from Orthochirus scrobilosus venom displayed blocking activity of $\mathrm{K}_{\mathrm{v}} 1.3$; however, during in vivo experiments, it demonstrated to be neurotoxic since it can diffuse immediately throughout the mouse brain (Mouhat et al., 2005). 6-7) Ts6 and Ts15 from Tityus serrulatus venom inhibit the proliferation of effector memory $\mathrm{T}$ cells and reduce inflammation in delayed-type hypersensitivity 
response using mice model (Pucca et al., 2016). 8) Vm24 from Vaejovis mexicanus smithi venom reduces delayed-type hypersensitivity reactions in rats (Varga et al., 2012), as well as impairs the synthesis and secretion of $\mathrm{T}$ cell cytokines in response to T-cell receptor engagement (Veytia-Bucheli et al., 2018).

Some reports have shown that maurocalcine from the scorpion Maurus palmatus, a toxin active on ryanodine receptors, goes into the cells and can also be used as a vector for the penetration of cell-impermeable cargo molecules. Mutated analogues of maurocalcine have been produced as leads to develop better cell-penetrating peptides (CPPs) (Esteve et al., 2005; Ram et al., 2009). CPPs are short (9-35 residues) cationic or amphipathic molecules with the capability of being rapidly internalized across cell membranes. In this way, they can mediate the translocation of a conjugated drug across plasma membranes, being considered an effective and non-toxic mechanism for drug delivery (Ramsey and Flynn, 2015). The first $\mathrm{Ca}^{2+}$ channel toxin from T. serrulatus venom, designated as CPP-Ts, exhibited selective internalization properties and specific nuclear delivery, being a potential intranuclear delivery tool to target cancerous cells (de Oliveira-Mendes et al., 2018).

\section{Sea Anemones}

Sea anemones, the polyp form of marine coelenterates of the phylum Cnidaria (Watters, 2005), are poorly studied, but represent a rich source of new compounds. ShK-186, originally isolated from Stichodactyla helianthus sea anemone venom, inspired the design of dalazatide, a synthetic peptide composed of 37 amino acids, acting as a $\mathrm{K}_{\mathrm{v}} 1.3$ inhibitor (Beeton et al., 2006). In preclinical tests, dalazatide have significantly reduced the clinical score of rat model of multiple sclerosis (Tarcha et al., 2012). Dalazatide completed phase I trials in 2015 to examine the safety of systemic multiple ascending dose administration in 32 healthy volunteers (NCT02446340) and in 24 patients with plaque psoriasis (NCT02435342). No phase II study has been started since then. However, public databases (e.g., the FDA, Drugs.com, etc.) do not mention what happened to this drug lead.

\section{Snakes}

Recently, collinein-1, a SVSP from Crotalus durissus collilineatus venom (Boldrini-França et al., 2015) was recombinantly expressed in Pichia pastoris system (Boldrini-Franca et al., 2019) and demonstrated to block, independently from its catalytic activity, the hEAG1 ion channel, which is overexpressed in several cell cancer lines. Collinein-1 reduced the viability of human breast cancer cell line MCF7, which displays high expression of hEAG1, but does not affect the HepG2 and MCF10A cell lines, which present low expression of this ion channel, demonstrating that the reduction of cell viability might be connected with hEAG1 inhibition by this protein (Boldrini-França et al., 2020).

Isolated from the Malayan pit viper (Calloselasma rhodostoma), ancrod is a thrombin-like enzyme able to release fibrinopeptide A from fibrinogen A $\alpha$ chain, causing hypofibrinogenemia in humans (Reid, 1971). Structurally, it is composed of 234 amino acids and presents six disulfide bonds (Burkhart et al., 1992). Because of its enzyme activity on fibrinogen (Chan et al., 2016), this toxin was used in stroke treatment (Pizzo et al., 1972), marketed for several decades by Knoll Pharma in Germany and Austria, until it was withdrawn in the 1980s (Chan et al., 2016). In 2002 the rights of this drug were licensed. Two parallel trials (NCT00141001 and NCT00300196) were in phase III of clinical trials by Neurobiological Technologies (NTI), but both studies were terminated due to low efficacy, suboptimal and inconsistent results which led to the dissolution of NTI in 2009 (King, 2011; Liu et al., 2011). A randomized study involving this molecule completed phase II trial in 31 patients with sudden hearing loss to check its effectiveness, safety, and tolerance for this kind of pathology in 2018 (NCT01621256).

The association of 15 residues of the C-terminal portion of Dendroaspis natriuretic peptide, isolated from $D$. angusticeps venom, with 22 residues of a human $\mathrm{C}$-type natriuretic peptide, formed the chimeric natriuretic peptide, cenderitide (CD-NP) (Lisy et al., 2008; Lee et al., 2009). It can be applied in congestive heart failure, and its mechanism of action is associated with the connection to natriuretic peptide receptors, leading to hypotension (Wei et al., 1993; Lee et al., 2009). Studies with this peptide completed phase I in 2007, in a non-randomized way, to check its efficacy, safety, and pharmacodynamics in 22 healthy participants (NCT00482937) (Lee et al., 2009; Ichiki et al., 2019). A phase II study in 14 patients with stable chronic heart failure (NCT02359227) and a phase I/II randomized study in 8 patients with chronic stable heart failure and moderate renal impairment (NCT02603614) were completed in February 2020. Another phase I randomized study to maintain the function of left ventricle in 30 participants with myocardial infarction was completed in 2019 (NCT02071602).

Fibrin sealant or fibrin glue, a bioproduct formed by a thrombin-like serine protease from $C$. $d$. terrificus venom and fibrinogen-rich cryoprecipitate from humans, could transmit infectious diseases and was suspended by the FDA in 1978 (Spotnitz, 2014; Ferreira et al., 2017). To overcome this drawback, the Center for the Study of Venoms and Venomous Animals (CEVAP) at São Paulo State University (UNESP), in Brazil, started studying the aforementioned fibrin sealant using a fibrinogen-rich cryoprecipitate from Bubalus bubalis buffaloes blood (Barros et al., 2009; Ferreira et al., 2017), and this bioproduct completed phase I/II of clinical trials with 10 patients in phase I and 30 patients in phase II (Ferreira et al., 2017). The fibrin glue displays adhesive, sealant and hemostatic effects due to its proteolytic activity on fibrinogen, producing fibrin monomers, which forms a clot in the presence of calcium (Barros et al., 2009; Ferreira et al., 2017). Similarly, preliminary studies have been conducted to evaluate the effect of direct application of Vivostat $^{\circledR}$ (autologous fibrin sealant) in controlling cerebral bleeding (Graziano et al., 2015; Graziano et al., 2016).

A $33 \mathrm{kDa}$-batroxobin from B. atrox and B. moojeni venoms (Itoh et al., 1987; Earps and Shoolingin-Jordan, 1998) was expressed in $P$. pastoris and exhibited biochemical activities 
similar to those of native protein (You et al., 2004). The recombinant batroxobin used with a medical adhesive synergistically accelerated hemostasis in the mouse liver and femoral artery models, reducing bleeding time and blood loss. Hemostasis was more rapidly achieved with increasing concentrations of batroxobin (You et al., 2014). Other dressings using collagen and chitosan with recombinant batroxobin also controlled bleeding and improved the hemostatic properties of collagen and chitosan pads used alone (Seon et al., 2017).

An analgesic preparation containing cobratide and oxycodone for cancer-related pain (CN104645312) and a keluoqu tablet preparation method using tramadol hydrochloride, ibuprofen and cobratide (also known as ketongning and cobrotoxin) (CN105769791) have been patented. The anti-nociceptive effects of cobrotoxin (the N. n. atra snake venom short-chain post-synaptic $\alpha$-neurotoxin cobratide) do not involve muscarinic acetylcholine or opioid receptors and the molecule has high affinity for the $\alpha_{1}$ subunit of the nicotinic acetylcholine receptors (nAChR) (Gazerani and Cairns, 2014). Cobratoxin, a long-chain post-synaptic $\alpha$ neurotoxin isolated from the Thailand cobra ( $N$. kaouthia), produces anti-nociceptive and anti-inflammatory effects through decreased production of inflammatory cytokines, for example, TNF- $\alpha$, IL-1, and IL-2, via its high affinity for the $\alpha_{7}$ subtype of nAChR (Gazerani and Cairns, 2014).

RPI-78M (Receptin ${ }^{\circledR}$ ) and RPI-MN (Pepteron ${ }^{\circledR}$ ) are detoxified and chemically modified forms of cobratoxin and cobrotoxin, respectively (King, 2011; Harvey, 2014). RPI-78M has 71 amino acid residues with five disulfide bonds and completed phase I of clinical trials for multiple sclerosis, while RPI-MN presents 62 amino acid residues and four disulfide bonds (King, 2011). Both molecules show analgesic applications and present the nAChRs as molecular target (Chan et al., 2016). Although RPI-MN is parenterally administered via subcutaneous injection, RPI-78M can be orally administered, since its absorption through the oral mucosa occurs when it is formulated with benzalkonium chloride (Reid and Raymond, 2010). Chemical modifications that detoxify these molecules can alter their affinity to nAChRs. They may include their oxidation with ozone, formate (also known as methanoate) and hydrogen peroxide, being the latter more adopted (Reid, 2007). RPI-MN has also completed preclinical studies against Human Immunodeficiency Virus (HIV), protecting cells due to its ability to inhibit viral replication (Reid, 2007; King, 2011; Harvey, 2014). However, its mechanism of action has not been elucidated yet (Reid and Raymond, 2010).

Crotamine, a highly cationic and cysteine-rich CPP from C. $d$. terrificus snake venom, displays membrane translocation capabilities, penetrates into the cell and presents cytoplasmatic, vesicular, and nuclear distribution (Kerkis et al., 2004). This toxin is specifically uptaken by actively proliferating cells, being able to permeate several lineages in vitro (Nascimento et al., 2007). Additionally, several molecules based on crotamine structure, including fluorescent derivatives (Tansi et al., 2019) and functionalized with gold nanoparticles (Karpel et al., 2018), for instance, are being developed. Crotamine and its analogues have been tested in healthy and tumorous cell lines, and the results indicate they can be used as selective delivery tools of anticancer molecules (Mambelli-Lisboa et al., 2018).

Another component isolated from $C$. $d$. terrificus venom is crotalphine (Konno et al., 2008), a potent analgesic comprised of 14 amino acid residues. It acts at peripheral opioid receptors (Gutierrez et al., 2008) and selectively targets TRPA1 ion channels (Bressan et al., 2016), being more potent under conditions of acute peripheral sensitization (Zambelli et al., 2014). The potent and long lasting opioid-mediated antinociception of crotalphine has been evaluated in cancer pain (Brigatte et al., 2013).

\section{Spiders}

The toxin $\pi$-theraphotoxin-Pcla or $\pi$-TRTX-Pcla (also known as psalmotoxin 1 or PcTx1), obtained from the Psalmopoeus cambridgei (Trinidad chevron tarantula) venom, is considered a novel therapeutic molecule for treating pain (Monge-Fuentes et al., 2018). Classified as a specific inhibitor of ASIC1a, the most abundant acid-sensing ion channel, the toxin $\pi$-TRTX-Pc1 demonstrated an effective analgesic effect comparable to morphine in rat models of acute pain (Mazzuca et al., 2007). Recently, PcTx1 was also reported as a valuable tool for understanding the functional role of ASIC2a heteromeric channels (ASIC1a/2a) (Liu et al., 2018) and had no effect on acid-induced transient or chronic hyperalgesia in a mouse model of fibromyalgia (Chang et al., 2019).

Hila, a PcTx1-related toxin isolated from the Australian funnel-web spider Hadronyche infensa, partially inhibits ASIC1a and does not affect ASIC1b (Maatuf et al., 2019). This toxin strongly attenuates brain damage after stroke and could be used to protect the brain from ischemic injury (Chassagnon et al., 2017), being considered as a lead for development of neuroprotective agents (Ren et al., 2018).

Purotoxin-1 (PT1), obtained from the central Asian spider Geolycosa sp. venom, has also been studied to pain treatment (Monge-Fuentes et al., 2018). Characterized as a specific antagonist of $\mathrm{P} 2 \mathrm{X} 3$ purinergic receptor, which is the most-studied subtype of P2X receptor related to pain, PT1 was able to inhibit nociceptive effect in different rat pain models (Grishin et al., 2010).

Phoneutria nigriventer (the armed spider) presents different toxins with potential pharmaceutical application and under preclinical tests (Peigneur et al., 2018). The toxin Pho1 $\beta$, classified as P/Q- and N-type voltage-gated calcium channel blocker, and its recombinant form (produced in E. coli) demonstrated analgesic effects in rodent models of pain (Souza et al., 2008). Recently, the same toxin $(P h \alpha 1 \beta)$ together with PhTx3-3 (also a voltage-gated calcium channel blocker) demonstrated significant inhibitory effects on the proliferation and viability of different glioma cell lines (M059J, U-138MG and $\mathrm{U}-251 \mathrm{MG})$ at low concentrations (0.3-100 pM). In the same study, Ph $\alpha 1 \beta$ and its recombinant form named CTK 01512-2 caused significant reductions of tumor areas in vivo using mouse glioblastoma model (Nicoletti et al., 2017). Moreover, Ph $\alpha 1 \beta$ and its recombinant version were able to reduce the inflammatory phase of the formalin-induced nociceptive behavior in rats, to decrease neuropathic pain caused by chronic constriction injury 
of sciatic nerve in rats, and to reduce the hyperalgesia caused by melanoma cancer model in mice (Rigo et al., 2017).

$P$. nigriventer venom became attractive because of its inducedpriapism effect. The $\delta$-ctenitoxin-Pn2a toxin, also known as $\delta$ CNTX-Pn2a or Tx2-6, modulates voltage-gated sodium $\left(\mathrm{Na}_{\mathrm{v}}\right)$ channels and demonstrated an erectile effect in rats $(12 \mu \mathrm{g} / \mathrm{kg}$, subcutaneous or intravenous injection) (Nunes et al., 2008). Interestingly, a minimum dose of $0.006 \mu \mathrm{g} / \mathrm{kg}$ directly injected into the corpus cavernosum can cause erection in mice (Andrade et al., 2008). A synthetic 19-amino acid peptide, PnPP-19, designed from active core of PnTx2-6 tertiary structure, potentiated erection in vivo and ex vivo via the nitric oxide/cyclic guanosine monophosphate pathway. PnPP-19 is a promising candidate for erectile dysfunction treatment in patients that do not respond to the usual therapies (Silva et al., 2015). Biozeus Biopharmaceutical S.A performed pilot tests with the topical peptide (renamed BZ371) on healthy human beings and has been performing a pilot test with voluntary men with erectile dysfunction associated to hypertension or diabetes. The regulatory toxicological preclinical tests have already started. The next steps involve the final marketing formulation and future clinical trials (Phases 1 and 2) (Biozeus Biopharmaceutical SA, 2018; Johnson \& Johnson, 2019)\{Johnson \& Johnson, 2019, Champions of Science ${ }^{\circledR}$ Storytelling Challenge: Latin America and Caribbean Edition;Biozeus Biopharmaceutical SA, 2018, First clinical trial sponsored by Biozeus concluded!\}.

Although antimicrobial activities with spider toxins are well documented (for detail see Spider Toxin Database, http:// arachnoserver.org), their therapeutic use are limited due to their susceptibility to proteolysis.

\section{Tetraodontiformes}

Tetrodotoxin (TTX), a guanidinium neurotoxin with high affinity for voltage-gated sodium $\left(\mathrm{Na}_{\mathrm{v}}\right)$ channels, had traditionally been known for many years as the main toxin from Tetraodontidae pufferfish (Lago et al., 2015). However, the toxin was present not only in other marine animals such as octopuses, gobies and sea stars, but also in phylogenetically unrelated terrestrial and aquatic organisms, including a dinoflagellate Alexandrium tamarense, red calcareous algae, arthropods, echinoderms, molluscs, worms, newts, frogs, and bacteria Actinomyces, Aeromonas, Alteromonas, Bacillus and Pseudomonas (Lago et al., 2015; Assuncao et al., 2017). The blockage of $\mathrm{Na}^{+}$into the cell inhibits the action potentials' propagation in the excitable cell membranes, which causes neuromuscular paralysis (Duran-Riveroll and Cembella, 2017). TTX has been used for the development of analgesic and anesthetic drugs (Assuncao et al., 2017; Vetter et al., 2017) and, under the trade name Tectin ${ }^{\circledR}$ (Wex Pharmaceuticals Inc.), proceeded to phase III of the clinical trials for the treatment of pain resulting from chemotherapy treatment in 2018 (NCT01655823).

\section{Other Animals}

The salivary secretion from different animals, such as bats, leeches, lizards, shrews and ticks are considered important sources of biologically active compounds. Other animals, such as caterpillars, have biologically active compounds in their bristles. Many of these compounds are still underexploited, lacking information on their chemical structure, physiological role and therapeutic application. Thus, the study of these compounds increases the chances of discovering new compounds with great pharmaceutical potential. The subsections Bats to Ticks will address some potential therapeutic molecules found in the saliva or bristles of these animals.

\section{Bats}

Desmoteplase, also known as "Desmodus rotundus salivary plasminogen activator" (DPSA), is a thrombolytic agent for acute ischemic stroke derived from vampire-bat saliva (Medcalf, 2012; Shi et al., 2016). This fibrin-dependent plasminogen activator is composed of 441 amino acids with high fibrin specificity, long half-life, low bleeding tendency, nonactivation by $\beta$-amyloid and lack of neurotoxicity (Medcalf, 2012; Shi et al., 2016; Li et al., 2017). A phase III randomized study in 492 participants with acute ischemic stroke was completed in 2015. Currently, there is no drug based on desmoteplase available for commercialization.

\section{Caterpillars}

Caterpillars from different South American countries, such as Venezuela, Brazil, French Guyana, Peru, Paraguay, Argentina and Colombia, are responsible for a severe bleeding syndrome in humans who touch their bristles (Arocha-Pinango and Guerrero, 2001). Lonomia obliqua is the main species of caterpillar found in Southern Brazil and its venom is comprised of molecules with antiviral, procoagulant, fibrinolytic and wound healing activities (Veiga et al., 2005; Reis et al., 2006; Alvarez-Flores et al., 2011; Carmo et al., 2015; Sato et al., 2016). Their toxic compounds are found in the bristle extract, hemolymph, cryosecretion (a crude venomous fluid ejected by the whole secretory tegument of caterpillars, stored at $-20^{\circ} \mathrm{C}$ for $24 \mathrm{~h}$ ) and tegument extract (Pinto et al., 2006; Veiga et al., 2009). Some compounds with potential therapeutic applications were identified in Lonomia sp, e.g. prothrombin or factor X activators, such as Lopap (L. obliqua prothrombim activator protease) and Losac (L. obliqua Stuart factor activator protease), $\mathrm{PLA}_{2}$-like, proteases, hyaluronidases, $\alpha$-fibrinogenases (e.g. Lonofibrase), protease inhibitors, serpins, lipocalins, and lectins (Veiga et al., 2009). Currently, there are three clinical studies on caterpillars recorded at the Clinical Trials website (US National Library of Medicine, 2020). However, these studies are related to their use as a source of protein in the diet and none of them involves the genus Lonomia.

\section{Leeches}

Two phase II randomized studies involving leech therapy in 118 (NCT00435773) and 60 participants (NCT02612974) with knee osteoarthritis were completed in 2007 and 2015, respectively. Additional information on FDA-approved hirudin analogues from $H$. medicinalis leech saliva and hirudotherapy was reported in section Achievements With Animal Toxin-Based Molecules. 


\section{Lizards}

Exenatide is the synthetic version of the native peptide exendin- 4 isolated from the saliva of Gila monster lizard (H. suspectum) (Eng et al., 1992; Furman, 2012). According to the Clinical Trials website, there are more than 300 clinical studies about exenatide. So far, there are 207 completed studies, 12 terminated, 25 whose status has not changed for 2 years, 47 recruiting volunteers, 11 that are not yet recruiting, and three enrolled by invitation. Among the clinical studies, exenatide has been used in patients with Parkinson's disease, showing beneficial effects on nerve cells by slowing down or stopping the degenerative process of this disease (NCT03456687). For an extensive review regarding clinical trials involving this drug, please see (Odegard and Desantis, 2009; Bhavsar et al., 2013). Additional information on exenatide was described in section Achievements With Animal Toxin-Based Molecules.

\section{Shrews}

SOR-C13 is a synthetic selective peptide inhibitor of Transient Receptor Potential Vanilloid 6 (TRPV6) calcium oncochannel (Pennington et al., 2017; Soricimed, 2018). It is comprised of 13 amino acids derived from the C-terminal region of the paralytic peptide soricidin (UniProtKB-P0C2P6), from the submaxillary and sublingual salivary glands of the Northern Short-tailed shrew (Blarina brevicauda) (Bowen et al., 2013; Fu et al., 2017). It inhibits the activation of nuclear factor of activated T-cell (NFAT) transcription complex, and induces apoptosis in TRPV6overexpressing cells (NIH National Cancer Institute, 2018). A phase I of study (NCT01578564) in 23 advanced cancer patients with TRPV6 channel overexpression was completed in 2016 and a phase I study (NCT03784677) started recruiting patients with advanced refractory solid tumors in 2019.

\section{Ticks}

There are several studies addressing the importance of tick saliva components. The use of evasins in the treatment of heart diseases, such as myocarditis (Singh et al., 2017) and the use of ixolaris, an anticoagulant protein from Ixodes scapularis tick saliva, to reduce HIV-driven coagulopathy, for instance (Schechter et al., 2017).

However, although tick saliva contains many components with therapeutic and biotechnological potentials, there are neither clinical studies involving the use of substances isolated from tick saliva nor drugs available for therapeutic purposes. The 101 clinical studies currently registered on the Clinical Trial website in respect to ticks are related to the development of vaccines against ticks or the use of different antibiotics in Lyme disease.

\section{FILLING THE GAP BETWEEN THE DRUG DISCOVERY AND ITS COMMERCIALIZATION-FUTURE TRENDS}

Animal poisons and venoms are comprised of a cocktail of bioactive components with a gamut of different activities.
Company pipelines worldwide are expanding the number of peptide-based products currently in development mainly because of the diversity of their application and activity. However, industrial production of toxin-related drugs from natural sources is quite challenging, laborious and presents restricted yield (Boldrini-França et al., 2017). To overcome these limitations, the main options are the chemical synthesis of peptides and the production of biopharmaceuticals via heterologous expression using biotechnological tools.

Recent data reinforces the advances in transcriptomics, proteomics and heterologous expression techniques, which allowed the characterization and potential production of low abundant active venom components, presenting low or high molecular mass (Boldrini-França et al., 2017). Additionally, pharmacomics has been gaining ground by integrating "omic" approaches to study dynamic molecular states and monitors disease states and drug responses, improving the development of novel drugs (Wilson and Daly, 2018).

The industry has focused on heterologous expression systems as an interesting alternative for manufacturing biopharmaceuticals of high molecular mass (Merlin et al., 2014). Recombinant protein production processes require extensive design and regulatory control before therapeutic products become commercially available. Regarding heterologous expression, the accurate cysteine bond formation and the proper incorporation of posttranslational modifications remain a challenge, and new technologies to assess and mitigate immunogenicity risk of engineered proteins are becoming more common. Therefore, a special attempt should be made to ensure that the recombinant protein presents comparable three-dimensional folding and consistent pharmacological properties when compared to its corresponding native form.

Native chemoselective reaction has been employed in the production of animal toxins with potential therapeutic application, such as mambalgin-2, a 57-amino acid analgesic peptide from three-finger toxins family, from Dendroaspis polylepis polylepis venom (Diochot et al., 2012; Harvey, 2014). This approach allows the synthesis of large proteins, since it is based in the production of different unprotected linear peptide fragments, which are condensed in solution via chemoselective reactions to originate the entire polypeptide (Kent et al., 2012). Studies to improve the protecting groups, resins, linkers, and activation and coupling reagents may enable the manufacture of larger peptides and even small proteins for therapeutic applications. However, the development of cheaper reagents and methods for the synthesis and purification of peptides are necessary.

Concerning the limitations of peptides in terms of their biopharmaceutical properties, designed approaches that will find molecules with intrinsically more favorable properties will need to be devised. As mentioned earlier in section Achievements With Animal Toxin-Based Molecules, the drug design of captopril made oral administration possible. Additionally, designed cationicityenhanced analogues of natural antimicrobial peptides have exhibited higher potency and spectra of antimicrobial activity (Luna-Ramirez et al., 2017). 
Achievements towards successful oral delivery of proteins and peptides by protecting them against degradation and increasing their absorption remain as an active area of research. Regarding toxin-based formulations, intranasal inoculation of hyaluronidase from $T$. serrulatus venom induced mononuclear increase in the bronchoalveolar space and became a promising tool for the treatment of pulmonary fibrosis (Bitencourt et al., 2011).

Some approaches to improve biopharmaceuticals delivery, such as alternative delivery routes, PEGylation and conjugation to (nano) carriers, represent a relevant step towards targeted delivery of toxinbased drugs. It is sobering to realize how little alternative delivery routes and bioconjugation strategies have been exploited to deliver toxin-based drugs, suggesting that studies on routes of distribution, delivery vehicles, cargo molecules, and targeting strategies are fruitful fields for future research.

Collinein-1, a thrombin-like serine protease from C. $d$. collilineatus, was successfully modified by site-specific PEGylation with maleimide-mPEG of $5 \mathrm{kDa}$ and exhibited higher catalytic efficiency and affinity for the substrate than the native form (da-Silva-Freitas et al., 2015). The PEGylated peptide HsTX1[R14A] from Heterometrus spinnifer scorpion venom showed higher plasma circulating half-life in rodents compared to the native peptide, which resulted in sustained efficacy in rodent models of multiple sclerosis and rheumatoid arthritis (Tanner et al., 2017).

In the drug development process, formulation patents using advanced drug release systems extend the market exclusivity of drugs, because of the high technical barrier to be overcome by generic manufacturers after the expiration of patents. Focusing on competitiveness, pharmaceutical companies have established strategic partnerships with leading academic institutions that have deep scientific expertise in novel concepts in the main areas of biology or chemistry. Some reports have shown the antitumor potential, among other applications, of animal venoms or their toxins conjugated with a wide variety of nanomaterials, such as silica, gold, chitosan, poly(D,L-Lactide)-based, and supermagnetic iron oxide nanoparticles (Badr et al., 2014; Utkin, 2017).

Studies on cell penetrating peptides (CPPs) have open unprecedented possibilities for vector applications in several fields, such as basic research, therapeutics, technology, and medical imaging. CPP-Ts, the first $\mathrm{Ca}^{2+}$ channel toxin from $T$. serrulatus venom, showed to be a potential intranuclear delivery tool to target cancerous cells (de Oliveira-Mendes et al., 2018). WaTx, a cell-penetrating toxin from the Australian black rock scorpion $U$. manicatus, reduced the permeability of the TRPA1 ion channel to $\mathrm{Ca}^{2+}$ ions and can be used as a tool to study the mechanisms involved in chronic pain (King et al., 2019).

Another field in ever-growing demand is the cosmeceutical industry, especially in Asia, where Korea is at the forefront of cosmeceutical development. Efficacy and safety studies on these products in humans are on high demand (Juhász et al., 2018).

\section{CONCLUSION}

Animal poisons and venoms are rich sources of molecules with a wide range of applications. However, to make the use of these molecules feasible, extensive preclinical trials are necessary, with some applications also requiring clinical trials (Figure 2).

Although the research in the field of toxinology tends to be quite challenging and time-consuming, the high selectivity of animal toxins for their targets turns them into promising leads for the development of effective therapeutic drugs. Studies on new engineered molecules with reduced side effects can be reached by untangling the interaction of venom peptides with their target. Therefore, we are still at a beginning phase in comprehending the complexity of animal venoms and poisons. While very few species have been extensively studied, we still have thousands of unexploited organisms, especially marine ones. Novel methods to produce and deliver biopharmaceuticals are expected to be

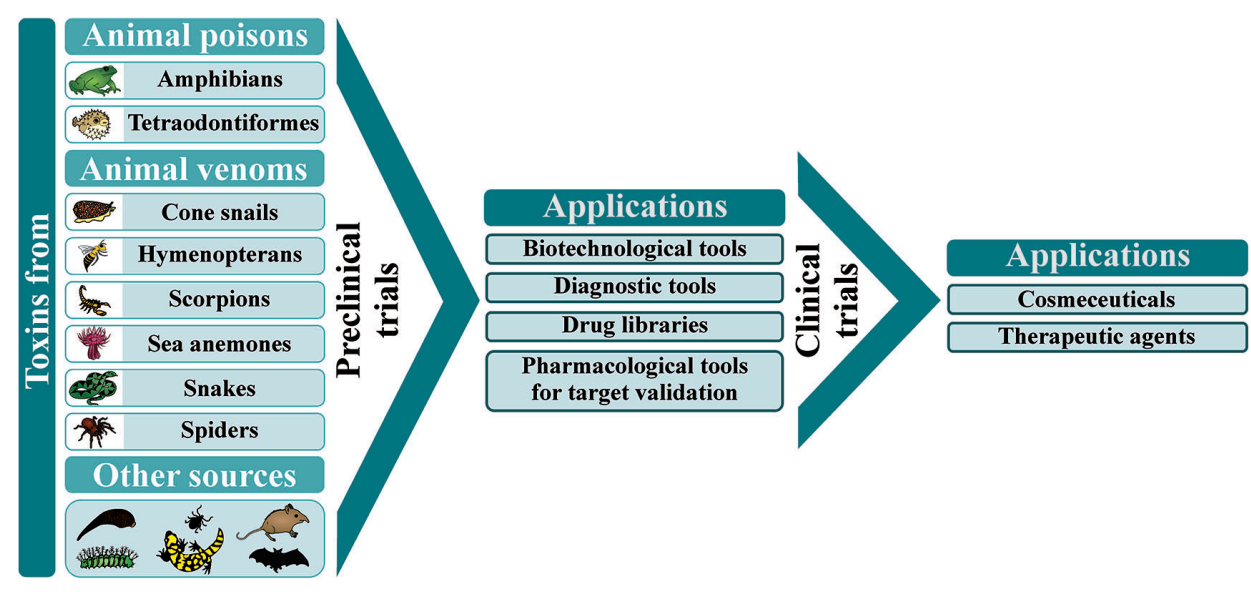

FIGURE 2 | Animal poisons and venoms as sources of candidate molecules for wide-ranging applications, after extensive characterization during preclinical and clinical trials. 
developed in the near future. With that in mind, we can get a glimpse of how much work on toxinology and drug discovery is yet to come in the next years.

\section{AUTHOR CONTRIBUTIONS}

$\mathrm{KB}$ and EA contributed to the conception and design of the study. $\mathrm{KB}$ and $\mathrm{EP}-\mathrm{J}$ wrote the first draft of the manuscript. $\mathrm{KB}$, CC, EF-B, EP-J, FCe, FGA, FPA, FCo, GW, IC, IF, IO, JB-F, MP, $\mathrm{MB}$, and EA wrote sections of the manuscript. FCe created the figures. $\mathrm{KB}, \mathrm{GW}, \mathrm{IC}$, and $\mathrm{IO}$ created the tables. All authors contributed to manuscript revision, read, and approved the submitted version.

\section{REFERENCES}

Abdualkader, A. M., Ghawi, A. M., Alaama, M., Awang, M., and Merzouk, A. (2013). Leech therapeutic applications. Indian J. Pharm. Sci. 75 (2), 127. doi: 10.4103/0250-474X.115456

Accardo, A., Galli, F., Mansi, R., Del Pozzo, L., Aurilio, M., Morisco, A., et al. (2016). Pre-clinical evaluation of eight DOTA coupled gastrin-releasing peptide receptor (GRP-R) ligands for in vivo targeting of receptor-expressing tumors. EJNMMI Res. 6 (1):17. doi: 10.1186/s13550-016-0175-x

Adis Insight (2018). RPI-78M. Available at: https://adisinsight.springer.com/ drugs/800020844 (Accessed June 22, 2020).

Adis Insight (2020). RPI-MN. Available at: https://adisinsight.springer.com/drugs/ 800025141 (Accessed June 22, 2020).

Ali, M.A.A.-S.M. (2012). Studies on bee venom and its medical uses. Int. J. $A d v$. Res. Technol. 1 (2), 69-83.

Alvarez-Flores, M. P., Furlin, D., Ramos, O. H. P., Balan, A., Konno, K., and Chudzinski-Tavassi, A. M. (2011). Losac, the first hemolin that exhibits procogulant activity through selective factor $\mathrm{X}$ proteolytic activation. J. Biol. Chem. 286 (9), 6918-6928. doi: 10.1074/jbc.M110.167718

Alves, P. L., Abdalla, F. M. F., Alponti, R. F., and Silveira, P. F. (2017). Antiobesogenic and hypolipidemic effects of a glucagon-like peptide-1 receptor agonist derived from the saliva of the Gila monster. Toxicon 135, 1-11. doi: 10.1016/j.toxicon.2017.06.001

Andrade, E., Villanova, F., Borra, P., Leite, K., Troncone, L., Cortez, I., et al. (2008). Penile erection induced in vivo by a purified toxin from the Brazilian spider Phoneutria nigriventer. BJU Int. 102 (7), 835-857. doi: 10.1111/j.1464410X.2008.07762.x

Arocha-Pinango, C. L., and Guerrero, B. (2001). Lonomia genus caterpillar envenomation: Clinical and biological aspects. Haemostasis 31 (3-6), 288293. doi: 10.1159/000048075

Assuncao, J., Guedes, A. C., and Malcata, F. X. (2017). Biotechnological and pharmacological applications of biotoxins and other bioactive molecules from dinoflagellates. Mar. Drugs 15 (12), 393. doi: 10.3390/md15120393

Badr, G., Sayed, D., Maximous, D., Mohamed, A. O., and Gul, M. (2014). Increased susceptibility to apoptosis and growth arrest of human breast cancer cells treated by a snake venom-loaded silica nanoparticles. Cell Physiol. Biochem. 34 (5), 1640-1651. doi: 10.1159/000366366

Baratto, L., Jadvar, H., and Iagaru, A. (2018). Prostate cancer theranostics targeting gastrin-releasing peptide receptors. Mol. Imaging Biol. 20 (4), 501-509. doi: 10.1007/s11307-017-1151-1

Barros, L. C., Ferreira, R. S.Jr., Barraviera, S. R. C. S., Stolf, H. O., ThomaziniSantos, I. A., Mendes-Giannini, M. J. S., et al. (2009). A new fibrin sealant from Crotalus durissus terrificus venom: applications in medicine. J. Toxicol. Environ. Health B Crit. Rev. 12 (8), 553-571. doi: 10.1080/10937400903442514

Bastos, E. M. A. F., Heneine, L. G. D., Pesquero, J. L., and Merlo, L. A. (2011). Pharmaceutical composition containing an Apitoxin fraction and use thereof, WO/2011/041865 patent application.

\section{FUNDING}

This study was supported by the São Paulo Research Foundation (FAPESP, grants 2017/04724-4 and 2019/10173-6, and scholarships to CC 2013/26200-6, EP-J 2016/04761-4; FCe 2017/ 14035-1 and 2018/14158-9; GW 2017/00586-6; ISO 2017/03580-9 and 2018/21233-7; KB 2013/26619-7), the National Council for Scientific and Technological Development (CNPq, grants 306479/ 2017-6 and 307155/2017-0 and scholarships to FCo 155276/2018-2 and FGA 150037/2018-0) and the Coordination for the Improvement of Higher Education Personnel (Coordenação de Aperfeiçoamento de Pessoal de Nível Superior-Brasil, CAPES, Finance Code 001, scholarships to EP-J 88881.186830/2018-01, GW, IF, IO, and JB-F).

Bayer Healthcare (2012). Discontinuation of Refludan ${ }^{\circledR}$ [lepirudin (rDNA) for injection]. Available at: https://www.hrsa.gov/sites/default/files/opa/ programrequirements/manufacturerletters/2012/refludan05312012.pdf (Accessed March 19, 2020).

Beeton, C., Wulff, H., Standifer, N. E., Azam, P., Mullen, K. M., Pennington, M. W., et al. (2006). Kv1.3 channels are a therapeutic target for T cell-mediated autoimmune diseases. Proc. Natl. Acad. Sci. U.S.A. 103 (46), 17414-17419. doi: $10.1073 /$ pnas.0605136103

Beeton, C. (2013). "Targets and therapeutic properties," in Handbook of biologically active peptides, 2nd ed. Ed. A. J. Kastin (Amsterdam: Elsevier), 473-482.

Bhavsar, S., Mudaliar, S., and Cherrington, A. (2013). Evolution of exenatide as a diabetes therapeutic. Curr. Diabetes Rev. 9 (2), 161-193. doi: 10.2174/ 1573399811309020007

Biocentury (2007). Pepteron (RPI-MN). Available at: https://bciq.biocentury.com/ products/pepteron_(rpi-mn) (Accessed March 19, 2020).

Biollaz, J., Burnier, M., Turini, G. A., Brunner, D. B., Porchet, M., Gomez, H. J., et al. (1981). Three new long-acting converting-enzyme inhibitors: relationship between plasma converting-enzyme activity and response to angiotensin I. Clin. Pharmacol. Ther. 29 (5), 665-670. doi: 10.1038/clpt.1981.92

Biozeus Biopharmaceutical SA (2018). First clinical trial sponsored by Biozeus concluded!. Available at: http://biozeus.com.br/first-clinical-trial-sponsoredby-biozeus-concluded/ (Accessed March 29, 2020).

Bitencourt, C. S., Pereira, P. A., Ramos, S. G., Sampaio, S. V., Arantes, E. C., Aronoff, D. M., et al. (2011). Hyaluronidase recruits mesenchymal-like cells to the lung and ameliorates fibrosis. Fibrogenesis Tissue Repair 4(1), 3. doi: $10.1186 / 1755-1536-4-3$

Bittl, J. A., Chaitman, B. R., Feit, F., Kimball, W., and Topol, E. J. (2001). Bivalirudin versus heparin during coronary angioplasty for unstable or postinfarction angina: Final report reanalysis of the Bivalirudin Angioplasty Study. Am. Heart J. 142 (6), 952-959. doi: 10.1067/mhj.2001.119374

Boldrini-França, J., Santos Rodrigues, R., Santos-Silva, L. K., de Souza, D. L., Gomes, M. S., Cologna, C. T., et al. (2015). Expression of a new serine protease from Crotalus durissus collilineatus venom in Pichia pastoris and functional comparison with the native enzyme. Appl. Microbiol. Biotechnol. 99 (23), 9971-9986. doi: 10.1007/s00253-015-6836-2

Boldrini-França, J., Cologna, C. T., Pucca, M. B., Bordon, K. C. F., Amorim, F. G., Anjolette, F. A. P., et al. (2017). Minor snake venom proteins: Structure, function and potential applications. Biochim. Biophys. Acta Gen. Subj. 1861 (4), 824-838. doi: 10.1016/j.bbagen.2016.12.022

Boldrini-Franca, J., Pinheiro-Junior, E. L., and Arantes, E. C. (2019). Functional and biological insights of rCollinein-1, a recombinant serine protease from Crotalus durissus collilineatus. J. Venom. Anim. Toxins Incl. Trop. Dis. 25, e147118. doi: 10.1590/1678-9199-jvatitd-1741-18

Boldrini-França, J., Pinheiro-Junior, E. L., Peigneur, S., Pucca, M. B., Cerni, F. A., Borges, R. J., et al. (2020). Beyond hemostasis: a snake venom serine protease with potassium channel blocking and potential antitumor activities. Sci. Rep. 10, 4476 (2020). doi: 10.1038/s41598-020-61258-x 
Bonifazi, F., Jutel, M., Bilo, B. M., Birnbaum, J., Muller, U., and Hy, E.I.G.I.V. (2005). Prevention and treatment of hymenoptera venom allergy: guidelines for clinical practice. Allergy 60 (12), 1459-1470. doi: 10.1111/j.13989995.2005.00960.x

Bowen, C. V., DeBay, D., Ewart, H. S., Gallant, P., Gormley, S., Ilenchuk, T. T., et al. (2013). In vivo detection of human TRPV6-rich tumors with anti-cancer peptides derived from soricidin. PloS One 8 (3), e58866. doi: 10.1371/ journal.pone.0058866

Braud, S., Bon, C., and Wisner, A. (2000). Snake venom proteins acting on hemostasis. Biochimie 82 (9-10), 851-859. doi: 10.1016/S0300-9084(00)01178-0

Bressan, E., Touska, F., Vetter, I., Kistner, K., Kichko, T. I., Teixeira, N. B., et al. (2016). Crotalphine desensitizes TRPAl ion channels to alleviate inflammatory hyperalgesia. Pain 157 (11), 2504-2516. doi: 10.1097/j.pain.0000000000000669

Brigatte, P., Konno, K., Gutierrez, V. P., Sampaio, S. C., Zambelli, V. O., Picolo, G., et al. (2013). Peripheral kappa and delta opioid receptors are involved in the antinociceptive effect of crotalphine in a rat model of cancer pain. Pharmacol. Biochem. Behav. 109, 1-7. doi: 10.1016/j.pbb.2013.04.012

Brinkhous, K. M., Read, M. S., Fricke, W. A., and Wagner, R. H. (1983). Botrocetin (venom coagglutinin) - Reaction with a broad-spectrum of multimeric forms of factor VIII macromolecular complex. Proc. Natl. Acad. Sci. U.S.A. -Biol. Sci. 80 (5), 1463-1466. doi: 10.1073/pnas.80.5.1463

Brogden, R. N., Todd, P. A., and Sorkin, E. M. (1988). Captopril - an update of its pharmacodynamic and pharmacokinetic properties, and therapeutic use in hypertension and congestive heart-failure. Drugs 36 (5), 540-600. doi: 10.2165/ 00003495-198836050-00003

Brust, A., Palant, E., Croker, D. E., Colless, B., Drinkwater, R., Patterson, B., et al. (2009). $\chi$-conopeptide pharmacophore development: toward a novel class of norepinephrine transporter inhibitor (Xen2174) for pain. J. Med. Chem. 52 (22), 6991-7002. doi: 10.1021/jm9003413

Buchaim, D. V., Cassaro, C. V., Shindo, J., Della Coletta, B. B., Pomini, K. T., Rosso, M. P. D., et al. (2019). Unique heterologous fibrin biopolymer with hemostatic, adhesive, sealant, scaffold and drug delivery properties: a systematic review. J. Venom. Anim. Toxins Incl. Trop. Dis. 25, e20190038. doi: 10.1590/1678-9199-jvatitd-2019-0038

Burkhart, W., Smith, G. F., Su, J. L., Parikh, I., and LeVine, H. (1992). Amino acid sequence determination of ancrod, the thrombin-like alpha-fibrinogenase from the venom of Agkistrodon rhodostoma. FEBS Lett. 297 (3), 297-301. doi: 10.1016/0014-5793(92)80559-Y

Butte, P. V., Mamelak, A., Parrish-Novak, J., Drazin, D., Shweikeh, F., Gangalum, P. R., et al. (2014). Near-infrared imaging of brain tumors using the Tumor Paint BLZ-100 to achieve near-complete resection of brain tumors. Neurosurg. Focus 36 (2), E1. doi: 10.3171/2013.11.FOCUS13497

Camargo, A. C. M., Ianzer, D., Guerreiro, J. R., and Serrano, S. M. T. (2012). Bradykinin-potentiating peptides: Beyond captopril. Toxicon 59 (4), 516-523. doi: 10.1016/j.toxicon.2011.07.013

Carmo, A. C. V., Yamasaki, L. H. T., Figueiredo, C. A., Giovanni, D., de Oliveira, M. I., dos Santos, F. C. P., et al. (2015). Discovery of a new antiviral protein isolated Lonomia obliqua analysed by bioinformatics and real-time approaches. Cytotechnology 67 (6), 1011-1022. doi: 10.1007/s10616-0149740-1

Cescato, R., Maina, T., Nock, B., Nikolopoulou, A., Charalambidis, D., Piccand, V., et al. (2008). Bombesin receptor antagonists may be preferable to agonists for tumor targeting. J. Nucl. Med. 49 (2), 318-326. doi: 10.2967/jnumed.107. 045054

Chan, Y. S., Cheung, R. C., Xia, L., Wong, J. H., Ng, T. B., and Chan, W. Y. (2016). Snake venom toxins: toxicity and medicinal applications. Appl. Microbiol. Biotechnol. 100 (14), 6165-6181. doi: 10.1007/s00253-016-7610-9

Chang, C. T., Fong, S. W., Lee, C. H., Chuang, Y. C., Lin, S. H., and Chen, C. C. (2019). Involvement of acid-sensing ion channel $1 \mathrm{~b}$ in the development of acid-induced chronic muscle pain. Front. Neurosci. 13:1247:1247. doi: 10.3389/ fnins.2019.01247

Chassagnon, I. R., McCarthy, C. A., Chin, Y. K. Y., Pineda, S. S., Keramidas, A., Mobli, M., et al. (2017). Potent neuroprotection after stroke afforded by a doubleknot spider-venom peptide that inhibits acid-sensing ion channel 1a. Proc. Natl. Acad. Sci. U.S.A. 114 (14), 3750-3755. doi: 10.1073/pnas.1614728114

Chen, C. W., Hu, Y. Q., Shi, X. W., Tao, C. H., Zheng, H. Y., Fei, W. D., et al. (2016). A single-label fluorescent derivatization method for quantitative determination of neurotoxin in vivo by capillary electrophoresis coupled with laser-induced fluorescence detection. Analyst 141 (14), 4495-4501. doi: $10.1039 / \mathrm{c} 6 \mathrm{an} 00327 \mathrm{c}$

Chow, S. C., and Chang, M. (2008). Adaptive design methods in clinical trials - a review. Orphanet J. Rare Dis. 3, 11. doi: 10.1186/1750-1172-3-11

Christensen, M., Knop, F. K., Holst, J. J., and Vilsboll, T. (2009). Lixisenatide, a novel GLP-1 receptor agonist for the treatment of type 2 diabetes mellitus. Idrugs 12 (8), 503-513.

Clark, R. J., Jensen, J., Nevin, S. T., Callaghan, B. P., Adams, D. J., and Craik, D. J. (2010). The engineering of an orally active conotoxin for the treatment of neuropathic pain. Angew. Chem. Int. Ed 49 (37), 6545-6548. doi: 10.1002/ anie. 201000620

Clark, G. C., Casewell, N. R., Elliott, C. T., Harvey, A. L., Jamieson, A. G., Strong, P. N., et al. (2019). Friends or foes? Emerging impacts of biological toxins. Trends Biochem. Sci. 44 (4), 365-379. doi: 10.1016/j.tibs.2018.12.004

Cohen-Inbar, O., and Zaaroor, M. (2016). Glioblastoma multiforme targeted therapy: The Chlorotoxin story. J. Clin. Neurosci. 33, 52-58. doi: 10.1016/ j.jocn.2016.04.012

Cooper, E. L., and Mologne, N. (2017). Exploiting leech saliva to treat osteoarthritis: A provocative perspective. J. Tradit. Complement Med. 7 (3), 367-369. doi: 10.1016/j.jtcme.2016.11.005

Cushman, D. W., Cheung, H. S., Sabo, E. F., and Ondetti, M. A. (1977). Design of potent competitive inhibitors of angiotensin-converting enzyme. Carboxyalkanoyl and mercaptoalkanoyl amino acids. Biochemistry 16 (25), 5484-5491. doi: 10.1021/bi00644a014

Daly, J. (2004). Chlorine compound of the month: Eptibatidine-natural frog poison with a surprising benefit to humans. Available at: https://chlorine. americanchemistry.com/Science-Center/Chlorine-Compound-of-the-MonthLibrary/Epibatidine-Natural-Frog-Poison-with-a-Surprising-Benefit-toHumans/ (Accessed March 19, 2020).

Das Gupta, S., Debnath, A., Saha, A., Giri, B., Tripathi, G., Vedasiromoni, J. R., et al. (2007). Indian black scorpion (Heterometrus bengalensis Koch) venom induced antiproliferative and apoptogenic activity against human leukemic cell lines U937 and K562. Leuk. Res. 31 (6), 817-825. doi: 10.1016/j.leukres.2006.06.004

da-Silva-Freitas, D., Boldrini-Franca, J., and Arantes, E. C. (2015). PEGylation: A successful approach to improve the biopharmaceutical potential of snake venom thrombin-like serine protease. Protein Pept. Lett. 22 (12), 1133-1139. doi: 10.2174/0929866522666151013130742

de Azevedo, R. A., Figueiredo, C. R., Ferreira, A. K., Matsuo, A. L., Massaoka, M. H., Girola, N., et al. (2015). Mastoparan induces apoptosis in B1 6F10-Nex2 melanoma cells via the intrinsic mitochondrial pathway and displays antitumor activity in vivo. Peptides 68, 113-119. doi: 10.1016/j.peptides. 2014.09.024

de Oliveira-Mendes, B. B. R., Horta, C. C. R., do Carmo, A. O., Biscoto, G. L., Sales-Medina, D. F., Leal, H. G., et al. (2018). CPP-Ts: a new intracellular calcium channel modulator and a promising tool for drug delivery in cancer cells. Sci. Rep. 8, 14739. doi: 10.1038/s41598-018-33133-3

DeBin, J. A., and Strichartz, G. R. (1991). Chloride channel inhibition by the venom of the scorpion Leiurus quinquestriatus. Toxicon 29 (11), 1403-1408. doi: 10.1016/0041-0101(91)90128-E

DeBin, J. A., Maggio, J. E., and Strichartz, G. R. (1993). Purification and characterization of chlorotoxin, a chloride channel ligand from the venom of the scorpion. Am. J. Physiol. 264 (2 Pt 1), C361-C369. doi: 10.1152/ ajpcell.1993.264.2.C361

DeYoung, M. B., MacConell, L., Sarin, V., Trautmann, M., and Herbert, P. (2011). Encapsulation of exenatide in poly-(D,L-lactide-co-glycolide) microspheres produced an investigational long-acting once-weekly formulation for type 2 diabetes. Diabetes Technol. Ther. 13 (11), 1145-1154. doi: 10.1089/ dia.2011.0050

Ding, J., Chua, P. J., Bay, B. H., and Gopalakrishnakone, P. (2014). Scorpion venoms as a potential source of novel cancer therapeutic compounds. Exp. Biol. Med. (Maywood) 239 (4), 387-393. doi: 10.1177/1535370213513991

Diochot, S., Baron, A., Salinas, M., Douguet, D., Scarzello, S., Dabert-Gay, A. S., et al. (2012). Black mamba venom peptides target acid-sensing ion channels to abolish pain. Nature 490 (7421), 552-555. doi: 10.1038/nature11494

Dodt, J., Müller, H.-P., Seemüller, U., and Chang, J.-Y. (1984). The complete amino acid sequence of hirudin, a thrombin specific inhibitor. Application of colour carboxymethylation. FEBS 165 (2), 180-184. doi: 10.1016/0014-5793 (84)80165-9 
Drug discovery and development (2016). Nutra Pharma announces manufacturing alliance with Omnia Biologics to produce RPI-78M for clinical trials in pediatric multiple sclerosis. Available at: https://www.drugdiscoverytrends.com/nutrapharma-omnias-manufacturing-alliance-to-produce-pediatric-ms-treatment/ (Accessed March 19, 2020).

Drugs.com (2020). Search. Available at: https://www.drugs.com/ (Accessed June $25,2020)$.

Duran-Riveroll, L. M., and Cembella, A. D. (2017). Guanidinium toxins and their interactions with voltage-gated sodium ion channels. Mar Drugs 15 (10), 303. doi: $10.3390 / \mathrm{md} 15100303$

Duskey, J. T., Belletti, D., Pederzoli, F., Vandelli, M. A., Forni, F., Ruozi, B., et al. (2017). Current strategies for the delivery of therapeutic proteins and enzymes to treat brain disorders. Int. Rev. Neurobiol. 137, 1-28. doi: 10.1016/ bs.irn.2017.08.006

Earps, L., and Shoolingin-Jordan, P. M. (1998). Molecular modelling of batroxobin on kallikreins. Biochem. Soc. Trans. 26 (3), S283-S283. doi: 10.1042/bst026s283

Elkinson, S., and Keating, G. M. (2013). Lixisenatide: First global approval. Drugs 73 (4), 383-391. doi: 10.1007/s40265-013-0033-3

Eng, J., Kleinman, W. A., Singh, L., Singh, G., and Raufman, J. P. (1992). Isolation and characterization of exendin-4, an exendin-3 analogue, from Heloderma suspectum venom. Further evidence for an exendin receptor on dispersed acini from guinea pig pancreas. J. Biol. Chem. 267 (11), 7402-7405.

Eriksson, U. G., Bredberg, U., Gislén, K., Johansson, L. C., Frison, L., Ahnoff, M., et al. (2003). Pharmacokinetics and pharmacodynamics of ximelagatran, a novel oral direct thrombin inhibitor, in young healthy male subjects. Eur. J. Clin. Pharmacol. 59 (1), 35-43. doi: 10.1007/s00228-003-0565-7

Esteve, E., Mabrouk, K., Dupuis, A., Smida-Rezgui, S., Altafaj, X., Grunwald, D., et al. (2005). Transduction of the scorpion toxin maurocalcine into cells Evidence that the toxin crosses the plasma membrane. J. Biol. Chem. 280 (13), 12833-12839. doi: 10.1047/jbc.M412521200

European Medicines Agency (2020). Search for medicines: Search our database of medicines - including human medicines, veterinary medicines and herbal medicines. Available at: https://www.ema.europa.eu/en (Accessed June 25, 2020).

Favaloro, E. J., and Wong, R. C. (2014). Antiphospholipid antibody testing for the antiphospholipid syndrome: a comprehensive practical review including a synopsis of challenges and recent guidelines. Pathology 46 (6), 481-495. doi: 10.1097/PAT.0000000000000142

Ferrajolo, C., Coloma, P. M., Verhamme, K. M. C., Schuemie, M. J., de Bie, S., Gini, R., et al. (2014). Signal detection of potentially drug-induced acute liver injury in children using a multi-country healthcare database network. Drug Saf. 37 (2), 99-108. doi: 10.1007/s40264-013-0132-9

Ferreira, S. H., and Rocha e Silva, M. (1965). Potentiation of bradykinin and eledoisin by BPF (bradykinin potentiating factor) from Bothrops jararaca venom. Experientia 21 (6), 347-349. doi: 10.1007/BF02144709

Ferreira, S. H., Bartelt, D. C., and Greene, L. J. (1970a). Isolation of bradykininpotentiating peptides from Bothrops jararaca venom. Biochemistry 9 (13), 2583-2593. doi: 10.1021/bi00815a005

Ferreira, S. H., Greene, L. H., Alabaster, V. A., Bakhle, Y. S., and Vane, J. R. (1970b). Activity of various fractions of bradykinin potentiating factor against angiotensin I converting enzyme. Nature 225 (5230), 379-380. doi: 10.1038/ $225379 \mathrm{a} 0$

Ferreira, R. S., de Barros, L. C., Abbade, L. P. F., Barraviera, S. R. C. S., Silvares, M. R. C., de Pontes, L. G., et al. (2017). Heterologous fibrin sealant derived from snake venom: from bench to bedside - an overview. J. Venom. Anim. Toxins Incl. Trop. Dis. 23, 21. doi: 10.1186/s40409-017-0109-8

Ferreira, S. H. (1965). A bradykinin-potentiating factor (BPF) present in the venom of Bothrops jararaca. Br. J. Pharmacol. Chemother. 24, 163-169. doi: 10.1111/j.1476-5381.1965.tb02091.x

Ferreira, S. H. (2000). Angiotensin converting enzyme: history and relevance. Semin. Perinatol. 24 (1), 7-10. doi: 10.1016/S0146-0005(00)80046-4

Fox, J. W., and Serrano, S. M. T. (2007). Approaching the golden age of natural product pharmaceuticals from venom libraries: An overview of toxins and toxin-derivatives currently involved in therapeutic or diagnostic applications. Curr. Pharm. Des. 13 (28), 2927-2934. doi: 10.2174/138161207782023739

Francischetti, I. M., and Gil, M. R. (2019). "Diagnostic use of venoms," in Transfusion Medicine and Hemostasis, 3rd ed. Eds. B. H. Shaz, C. D. Hillyer and M. R. Gil (Amsterdam: Elsevier), 969-975.
Fu, Y. J., Yin, L. T., Liang, A. H., Zhang, C. F., Wang, W., Chai, B. F., et al. (2007). Therapeutic potential of chlorotoxin-like neurotoxin from the Chinese scorpion for human gliomas. Neurosci. Lett. 412 (1), 62-67. doi: 10.1016/ j.neulet.2006.10.056

Fu, Y., Zheng, S., Huang, R., An, N., Zheng, Y., Zhang, Z., et al. (2012). A potential strategy for high-grade gliomas: combination treatment with lithium chloride and BmK CT. Biotechnol. Lett. 34 (1), 9-17. doi: 10.1007/s10529-011-0741-2

Fu, S., Hirte, H., Welch, S., Ilenchuk, T. T., Lutes, T., Rice, C., et al. (2017). First-inhuman phase I study of SOR-C13, a TRPV6 calcium channel inhibitor, in patients with advanced solid tumors. Invest. New Drugs 35 (3), 324-333. doi: 10.1007/s10637-017-0438-z

Funk, C., Gmur, J., Herold, R., and Straub, P. W. (1971). Reptilase ${ }^{\circledR}$ - a new reagent in blood coagulation. Br. J. Haematol. 21 (1), 43-\&. doi: 10.1111/j.13652141.1971.tb03415.x

Furman, B. L. (2012). The development of Byetta (exenatide) from the venom of the Gila monster as an anti-diabetic agent. Toxicon 59 (4), 464-471. doi: $10.1016 /$ j.toxicon.2010.12.016

Gajski, G., and Garaj-Vrhovac, V. (2013). Melittin: A lytic peptide with anticancer properties. Environ. Toxicol. Pharmacol. 36 (2), 697-705. doi: 10.1016/ j.etap.2013.06.009

Gan, Z. R., Gould, R. J., Jacobs, J. W., Friedman, P. A., and Polokoff, M. A. (1988). ). Echistatin. A potent platelet aggregation inhibitor from the venom of the viper Echis carinatus. J. Biol. Chem. 263 (36), 19827-19832.

Gao, B., Peng, C., Yang, J., Yi, Y., Zhang, J., and Shi, Q. (2017). Cone snails: a big store of conotoxins for novel drug discovery. Toxins 9 (12):397. doi: 10.3390/ toxins 9120397

Gazerani, P., and Cairns, B. E. (2014). Venom-based biotoxins as potential analgesics. Expert Rev. Neurother. 14 (11), 1261-1274. doi: 10.1586/ 14737175.2014 .962518

Ghosh, A., Roy, R., Nandi, M., and Mukhopadhyay, A. (2019). Scorpion venomtoxins that aid in drug development: a review. Int. J. Pept. Res. Ther. 25 (1), $27-$ 37. doi: 10.1007/s10989-018-9721-x

Gomes, A., Teixeira, C., Ferraz, R., Prudencio, C., and Gomes, P. (2017). Woundhealing peptides for treatment of chronic diabetic foot ulcers and other infected skin injuries. Molecules 22 (10), 1743. doi: 10.3390/molecules22101743

Gotter, A. (2019). Apitherapy. Available at: https://www.healthline.com/health/ apitherapy (Accessed June 25, 2020).

Graetz, T. J., Tellor, B. R., Smith, J. R., and Avidan, M. S. (2011). Desirudin: a review of the pharmacology and clinical application for the prevention of deep vein thrombosis. Expert Rev. Cardiovasc. Ther. 9 (9), 1101-1109. doi: 10.1586/erc.11.131

Graziano, F., Certo, F., Basile, L., Maugeri, R., Grasso, G., Meccio, F., et al. (2015). Autologous fibrin sealant $\left(\right.$ Vivostat $^{\circledR)}$ in the neurosurgical practice: Part I: Intracranial surgical procedure. Surg. Neurol. Int. 6, 77. doi: 10.4103/21527806.156871

Graziano, F., Maugeri, R., Basile, L., Meccio, F., and Iacopino, D. G. (2016). Aulogous fibrin sealant $\left(\right.$ Vivostat $\left.^{\circledR}\right)$ in the neurosurgical practice: Part II: Vertebro-spinal procedures. Surg. Neurol. Int. 7 (Suppl 3), S77-S82. doi: 10.4103/2152-7806.174894

Greig, N. H., Holloway, H. W., De Ore, K. A., Jani, D., Wang, Y., Zhou, J., et al. (1999). Once daily injection of exendin-4 to diabetic mice achieves long-term beneficial effects on blood glucose concentrations. Diabetologia 42 (1), 45-50. doi: $10.1007 / \mathrm{s} 001250051111$

Grishin, E. V., Savchenko, G. A., Vassilevski, A. A., Korolkova, Y. V., Boychuk, Y. A., Viatchenko-Karpinski, V. Y., et al. (2010). Novel peptide from spider venom inhibits P2X3 receptors and inflammatory pain. Ann. Neurol. 67 (5), 680-683. doi: 10.1002/ana.21949

Gulseth, M. P. (2005). Ximelagatran: An orally active direct thrombin inhibitor. Am. J. Health Syst. Pharm. 62 (14), 1451-1467. doi: 10.2146/ajhp040534

Gutierrez, V. P., Konno, K., Chacur, M., Sampaio, S. C., Picolo, G., Brigatte, P., et al. (2008). Crotalphine induces potent antinociception in neuropathic pain by acting at peripheral opioid receptors. Eur. J. Pharmacol. 594 (1-3), 84-92. doi: 10.1016/j.ejphar.2008.07.053

Han, T. S., Teichert, R. W., Olivera, B. M., and Bulaj, G. (2008). Conus venoms - A rich source of peptide-based therapeutics. Curr. Pharm. Des. 14 (24), 24622479. doi: $10.2174 / 138161208785777469$

Han, S. M., Hong, I. P., Woo, S. O., Chun, S. N., Park, K. K., Nicholls, Y. M., et al. (2015). The beneficial effects of honeybee-venom serum on facial wrinkles in humans. Clin. Interv. Aging 10, 1587-1592. doi: 10.2147/cia.s84940 
Hartman, G. D., Egbertson, M. S., Halczenko, W., Laswell, W. L., Duggan, M. E., Smith, R. L., et al. (1992). Non-peptide fibrinogen receptor antagonists. 1. Discovery and design of exosite inhibitors. J. Med. Chem. 35 (24), 4640-4642. doi: 10.1021/jm00102a020

Hartmann, A., Mullner, J., Meier, N., Hesekamp, H., van Meerbeeck, P., Habert, M. O., et al. (2016). Bee venom for the treatment of Parkinson disease - A randomized controlled clinical trial. PloS One 11 (7), e0158235. doi: 10.1371/ journal.pone. 0158235

Harvey, A. L. (2014). Toxins and drug discovery. Toxicon 92, 193-200. doi: 10.1016/j.toxicon.2014.10.020

Hennerici, M. G., Kay, R., Bogousslavsky, J., Lenzi, G. L., Verstraete, M., Orgogozo, J. M., et al. (2006). Intravenous ancrod for acute ischaemic stroke in the European Stroke Treatment with Ancrod Trial: a randomised controlled trial. Lancet 368 (9550), 1871-1878. doi: 10.1016/S0140-6736(06)69776-6

Henry, R. R., Rosenstock, J., Logan, D., Alessi, T., Luskey, K., and Baron, M. A. (2014). Continuous subcutaneous delivery of exenatide via ITCA 650 leads to sustained glycemic control and weight loss for 48 weeks in metformin-treated subjects with type 2 diabetes. J. Diabetes Complicat. 28 (3), 393-398. doi: 10.1016/j.jdiacomp.2013.12.009

Hockaday, D. C., Shen, S., Fiveash, J., Raubitschek, A., Colcher, D., Liu, A., et al. (2005). Imaging glioma extent with 131I-TM-601. J. Nucl. Med. 46 (4), 580586.

Holleman, W. H., and Weiss, L. J. (1976). The thrombin-like enzyme from Bothrops atrox snake venom. Properties of the enzyme purified by affinity chromatography on p-aminobenzamidine-substituted agarose. J. Biol. Chem. 251 (6), 1663-1669.

Huang, J., Han, S., Sun, Q., Zhao, Y. P., Liu, J. C., Yuan, X. L., et al. (2017). Kv1.3 channel blocker (ImKTx88) maintains blood-brain barrier in experimental autoimmune encephalomyelitis. CellBiosci 7, 31. doi: 10.1186/s13578-017$0158-2$

Ibraheem, D., Elaissari, A., and Fessi, H. (2014). Administration strategies for proteins and peptides. Int. J. Pharm. 477, 578-589. doi: 10.1016/j.ijpharm. 2014.10.059

Ichiki, T., Dzhoyashvili, N., and Burnett, J. C. (2019). Natriuretic peptide based therapeutics for heart failure: Cenderitide: A novel first-in-class designer natriuretic peptide. Int. J. Cardiol. 281, 166-171. doi: 10.1016/j.ijcard.2018. 06.002

Ikonen, S., and Riekkinen, P. (1999). Effects of apamin on memory processing of hippocampal-lesioned mice. Eur. JPharmacol. 382 (3), 151-156. doi: 10.1016/ s0014-2999(99)00616-0

Itoh, N., Tanaka, N., Mihashi, S., and Yamashina, I. (1987). Molecular cloning and sequence analysis of cDNA for batroxobin, a thrombin-like snake venom enzyme. J. Biol. Chem. 262 (7), 3132-3135.

Jacoby, D. B., Dyskin, E., Yalcin, M., Kesavan, K., Dahlberg, W., Ratliff, J., et al. (2010). Potent pleiotropic anti-angiogenic effects of TM601, a synthetic chlorotoxin peptide. Anticancer Res. 30 (1), 39-46.

Jagua-Gualdrón, A., Peña-Latorre, J. A., and Fernadez-Bernal, R. E. (2020). Apitherapy for osteoarthritis: perspectives from basic research. Complement Med. Res. 27 (3), 184-192. doi: 10.1159/000505015

Jang, S. H., Choi, S. Y., Ryu, P. D., and Lee, S. Y. (2011). Anti-proliferative effect of Kv1.3 blockers in A549 human lung adenocarcinoma in vitro and in vivo. Eur. J. Pharmacol. 651 (1-3), 26-32. doi: 10.1016/j.ejphar.2010.10.066

Johnson \& Johnson (2019). Champions of Science ${ }^{\circledR}$ Storytelling Challenge: Latin America and Caribbean Edition. Available at: https://www.jnj.com/latinamerica-caribbean-storytelling-challenge/maria-elena-de-lima (Accessed March 29, 2020).

Johnson, P. H., Sze, P., Winant, R., Payne, P. W., and Lazar, J. B. (1989). Biochemistry and genetic-engineering of hirudin. Semin. Thromb. Hemost. 15 (3), 302-315. doi: 10.1055/s-2007-1002723

Jones, S., and Howl, J. (2012). Enantiomer-specific bioactivities of peptidomimetic analogues of mastoparan and mitoparan: Characterization of inverso mastoparan as a highly efficient cell penetrating peptide. Bioconj. Chem. 23 (1), 47-56. doi: 10.1021/bc2002924

Juhász, M. L., Levin, M. K., and Marmur, E. S. (2018). The use of natural ingredients in innovative Korean cosmeceuticals. J. Cosmet. Dermatol. 17, 1-8. doi: 10.1111/ jocd.12492

Karpel, R. L., Liberato, M. D., Campeiro, J. D., Bergeon, L., Szychowski, B., Butler, A., et al. (2018). Design and characterization of crotamine-functionalized gold nanoparticles. Colloids Surf B Biointerfaces 163, 1-8. doi: 10.1016/j.colsurfb. 2017.12.013

Kent, S., Sohma, Y., Liu, S., Bang, D., Pentelute, B., and Mandal, K. (2012). Through the looking glass - a new world of proteins enabled by chemical synthesis. J. Pept. Sci. 18 (7), 428-436. doi: 10.1002/psc.2421

Kerkis, A., Kerkis, I., Radis-Baptista, G., Oliveira, E. B., Vianna-Morgante, A. M., Pereira, L. V., et al. (2004). Crotamine is a novel cell-penetrating protein from the venom of rattlesnake Crotalus durissus terrificus. FASEB J. 18 (10), 1407140+. doi: 10.1096/fi.03-1459fje

Kesavan, K., Ratliff, J., Johnson, E. W., Dahlberg, W., Asara, J. M., Misra, P., et al. (2010). Annexin A2 is a molecular target for TM601, a peptide with tumortargeting and anti-angiogenic effects. J. Biol. Chem. 285 (7), 4366-4374. doi: 10.1074/jbc.M109.066092

Kineta Inc. (2020). KCP-506 - A novel non-opioid for the treatment of chronic pain. Available at: https://kinetabio.com/neuroscience/ (Accessed March 29, 2020).

King, J. V. L., Emrick, J. J., Kelly, M. J. S., Herzig, V., King, G. F., Medzihradszky, K. F., et al. (2019). A cell-penetrating scorpion toxin enables mode-specific modulation of TRPA1 and pain. Cell 178 (6), 1362-136+. doi: 10.1016/ j.cell.2019.07.014

King, G. F. (2011). Venoms as a platform for human drugs: translating toxins into therapeutics. Expert Opin. Biol. Ther. 11 (11), 1469-1484. doi: 10.1517/ 14712598.2011 .621940

King, G. F. (2013). Venoms to drugs: translating venom peptides into therapeutics. Aust. Biochem. 44 (3), 13-16.

Kjaergard, H. K., and Trumbull, H. R. (1998). Vivostat system autologous fibrin sealant: Preliminary study in elective coronary bypass grafting. Ann. Thorac. Surg. 66 (2), 482-486. doi: 10.1016/s0003-4975(98)00470-6

Knop, F. K., Bronden, A., and Vilsboll, T. (2017). Exenatide: pharmacokinetics, clinical use, and future directions. Expert Opin. Pharmacother. 18 (6), 555-571. doi: 10.1080/14656566.2017.1282463

Koh, C. Y., and Kini, R. M. (2008). Anticoagulants from hematophagous animals. Expert Rev. Hematol. 1 (2), 135-139. doi: 10.1586/17474086.1.2.135

Koh, C. Y., and Kini, R. M. (2012). From snake venom toxins to therapeutics cardiovascular examples. Toxicon 59 (4), 497-506. doi: 10.1016/j.toxicon. 2011.03.017

Koh, D. C. I., Armugam, A., and Jeyaseelan, K. (2006). Snake venom components and their applications in biomedicine. Cell Mol. Life Sci. 63 (24), 3030-3041. doi: 10.1007/s00018-006-6315-0

Kolaczek, A., Skorupa, D., Antczak-Marczak, M., Kuna, P., and Kupczyk, M. (2017). Safety and efficacy of venom immunotherapy: a real life study. Postepy DermatolAlergol. 34 (2), 159-167. doi: 10.5114/ada.2017.67082

Kolosov, A., Goodchild, C. S., and Cooke, I. (2010). CNSB004 (leconotide) causes antihyperalgesia without side effects when given intravenously: a comparison with ziconotide in a rat model of diabetic neuropathic pain. Pain Med. 11 (2), 262-273. doi: 10.1111/j.1526-4637.2009.00741.x

Konno, K., Picolo, G., Gutierrez, V. P., Brigatte, P., Zambelli, V. O., Camargo, A. C. M., et al. (2008). Crotalphine, a novel potent analgesic peptide from the venom of the South American rattlesnake Crotalus durissus terrificus. Peptides 29 (8), 1293-1304. doi: 10.1016/j.peptides.2008.04.003

Kovalainen, M., Monkare, J., Riikonen, J., Pesonen, U., Vlasova, M., Salonen, J., et al. (2015). Novel delivery systems for improving the clinical use of peptides. Pharmacol. Rev. 67 (3), 541-561. doi: 10.1124/pr.113.008367

Kovar, J. L., Curtis, E., Othman, S. F., Simpson, M. A., and Olive, D. M. (2013). Characterization of IRDye $800 \mathrm{CW}$ chlorotoxin as a targeting agent for brain tumors. Anal. Biochem. 440 (2), 212-219. doi: 10.1016/j.ab.2013.05.013

Ladram, A., and Nicolas, P. (2016). Antimicrobial peptides from frog skin: biodiversity and therapeutic promises. Front. Biosci. 21, 1341-1371. doi: $10.2741 / 4461$

Lago, J., Rodriguez, L. P., Blanco, L., Vieites, J. M., and Cabado, A. G. (2015). Tetrodotoxin, an extremely potent marine neurotoxin: distribution, toxicity, origin and therapeutical uses. Mar Drugs 13 (10), 6384-6406. doi: 10.3390/ md13106384

Lang, S., Manning, N., Armstrong, N., Misso, K., Allen, A., Di Nisio, M., et al. (2012). Treatment with tirofiban for acute coronary syndrome (ACS): a systematic review and network analysis. Curr. Med. Res. Opin. 28 (3), 351370. doi: $10.1185 / 03007995.2012 .657299$

Lee, C. J., and Ansell, J. E. (2011). Direct thrombin inhibitors. Br. JClin. Pharmacol. 72 (4), 581-592. doi: $10.1111 / j .1365-2125.2011 .03916 . x$ 
Lee, C. Y., Chen, H. H., Lisy, O., Swan, S., Cannon, C., Lieu, H. D., et al. (2009). Pharmacodynamics of a novel designer natriuretic peptide, CD-NP, in a firstin-human clinical trial in healthy subjects. J. Clin. Pharmacol. 49 (6), 668-673. doi: 10.1177/0091270009336233

Lee, J. A., Son, M. J., Choi, J., Jun, J. H., Kim, J. I., and Lee, M. S. (2014). Bee venom acupuncture for rheumatoid arthritis: a systematic review of randomised clinical trials. BMJ Open 4, e006140. doi: 10.1136/bmjopen-2014-006140

Lewis, R. J., Dutertre, S., Vetter, I., and Christie, M. J. (2012). Conus venom peptide pharmacology. Pharmacol. Rev. 64 (2), 259-298. doi: 10.1124/pr.111.005322

Lewis, R. J. (2015). "Case study 1: development of the analgesic drugs Prialt ${ }^{\circledR}$ and Xen2174 from cone snail venoms," in Venoms to drugs: venom as a source for the development of human therapeutics. Ed. G. F. King (London: Royal Society of Chemistry), 245-254.

Li, C., Hashimi, S. M., Cao, S., Mellick, A. S., Duan, W., Good, D., et al. (2013). The mechanisms of chansu in inducing efficient apoptosis in colon cancer cells. Evid. Based Complement Alternat. Med. 2013:849054. doi: 10.1155/2013/849054

Li, X., Ling, L., Li, C., and Ma, Q. (2017). Efficacy and safety of desmoteplase in acute ischemic stroke patients: A systematic review and meta-analysis. Medicine 96 (18), e6667. doi: 10.1097/md.0000000000006667

Lippens, G., Najib, J., Wodak, S. J., and Tartar, A. (1995). NMR sequential assignments and solution structure of chlorotoxin, a small scorpion toxin that blocks chloride channels. Biochemistry 34 (1), 13-21. doi: 10.1021/ bi00001a003

Lisy, O., Huntley, B. K., McCormick, D. J., Kurlansky, P. A., and Burnett, J. C. (2008). ). Design, synthesis, and actions of a novel chimeric natriuretic peptide: CD-NP. J. Am. Coll. Cardiol. 52 (1), 60-68. doi: 10.1016/j.jacc.2008.02.077

Liu, S., Marder, V. J., Levy, D. E., Wang, S. J., Yang, F., Paganini-Hill, A., et al. (2011). Ancrod and fibrin formation: perspectives on mechanisms of action. Stroke 42 (11), 3277-3280. doi: 10.1161/STROKEAHA.111.622753

Liu, Y., Ban, L. Y., Su, X., Gao, S., Liu, J. W., and Cui, X. N. (2015). Effects of cinobufacini injection on cell proliferation and the expression of topoisomerases in human HepG-2 hepatocellular carcinoma cells. Mol. Med. Rep. 12 (1), 1598-1604. doi: 10.3892/mmr.2015.3552

Liu, Y., Hagan, R., and Schoellerman, J. (2018). Dual actions of Psalmotoxin at ASIC1a and ASIC2a heteromeric channels (ASIC1a/2a). Sci. Rep. 8, 7179. doi: 10.1038/s41598-018-25386-9

Lorenz, M., Evers, A., and Wagner, M. (2013). Recent progress and future options in the development of GLP-1 receptor agonists for the treatment of diabesity. Bioorg. Med. Chem. Lett. 23 (14), 4011-4018. doi: 10.1016/j.bmcl.2013.05.022

Luna-Ramirez, K., Tonk, M., Rahnamaeian, M., and Vilcinskas, A. (2017). Bioactivity of natural and engineered antimicrobial peptides from venom of the scorpions Urodacus yaschenkoi and U. manicatus. Toxins 9 (1), 22. doi: $10.3390 /$ toxins 9010022

Maatuf, Y., Geron, M., and Priel, A. (2019). The role of toxins in the pursuit for novel analgesics. Toxins 11 (2):131. doi: 10.3390/toxins11020131

Mabrouk, K., Luis, J., De Pomyers, H., Bertin, D., Bengeloune, A. H., Verdoni, M., et al. (2018). Use of spider venoms for skin whitening/depigmenting and composition comprising spider venoms molecules or synthetic analogs, WO/ 2014/037111 patent application.

Mambelli-Lisboa, N. C., Sciani, J. M., da Silva, A., and Kerkis, I. (2018). Colocalization of crotamine with internal membranes and accentuated accumulation in tumor cells. Molecules 23 (4), 968. doi: 10.3390/molecules 23040968

Manda, P., Kushwaha, A. S., Kundu, S., Shivakumar, H. N., Jo, S. B., and Murthy, S. N. (2016). Delivery of ziconotide to cerebrospinal fluid via intranasal pathway for the treatment of chronic pain. J. Control Release 224, 69-76. doi: 10.1016/j.jconrel.2015.12.044

Maraganore, J. M., Bourdon, P., Jablonski, J., Ramachandran, K. L., and Fenton, J. W. (1990). Design and characterization of hirulogs: a novel class of bivalent peptide inhibitors of thrombin. Biochemistry 29 (30), 7095-7101. doi: 10.1021/ bi00482a021

Markland, F. S., and Swenson, S. (2010). Fibrolase: trials and tribulations. Toxins 2 (4), 793-808. doi: 10.3390/toxins 2040793

Markwardt, F. (1991). Past, present and future of hirudin. Haemostasis 21 Suppl 1, 11-26. doi: 10.1159/000216258

Mazzuca, M., Heurteaux, C., Alloui, A., Diochot, S., Baron, A., Voilley, N., et al. (2007). A tarantula peptide against pain via ASIC1a channels and opioid mechanisms. Nat. Neurosci. 10 (8), 943-945. doi: 10.1038/nn1940
Mazzucco, L., Balbo, V., Cattana, E., and Borzini, P. (2008). Platelet-rich plasma and platelet gel preparation using Plateltex ${ }^{\circledR}$. Vox Sang 94 (3), 202-208. doi: 10.1111/j.1423-0410.2007.01027.x

McGivern, J. G. (2007). Ziconotide: a review of its pharmacology and use in the treatment of pain. Neuropsychiatr. Dis. Treat 3 (1), 69-85. doi: 10.2147/ nedt.2007.3.1.69

Medcalf, R. L. (2012). Desmoteplase: discovery, insights and opportunities for ischaemic stroke. Br. J. Pharmacol. 165 (1), 75-89. doi: 10.1111/j.14765381.2011.01514.x

Medicure Pharma (2016). Aggrastat (Tirofiban hydrochloride) injection premixed and injection prescribing information (Somerset, USA). Available at: https:// www.aggrastathdb.com/product-formats (Accessed March 19, 2020).

Mehrzad, M., Tuktamyshov, R., and Mehrzad, R. (2017). Safety, efficiency and cost effectiveness of Bivalirudin: A systematic review. World J. Cardiol. 9 (9), 761772. doi: 10.4330/wjc.v9.i9.761

Meng, Z., Yang, P., Shen, Y., Bei, W., Zhang, Y., Ge, Y., et al. (2009). Pilot study of huachansu in patients with hepatocellular carcinoma, nonsmall-cell lung cancer, or pancreatic cancer. Cancer 115 (22), 5309-5318. doi: 10.1002/cncr.24602

Merlin, M., Gecchele, E., Capaldi, S., Pezzotti, M., and Avesani, L. (2014). Comparative evaluation of recombinant protein production in different biofactories: the green perspective. BioMed. Res. Int. 2014:14. doi: 10.1155/ 2014/136419

Messier, C., Mourre, C., Bontempi, B., Sif, J., Lazdunski, M., and Destrade, C. (1991). Effect of apamin, a toxin that inhibits $\mathrm{Ca} 2^{+-}$dependent $\mathrm{K}+$ channels, on learning and memory processes. Brain Res. 551 (1-2), 322-326. doi: 10.1016/ 0006-8993(91)90950-z

Miao, Q., Bi, L. L., Li, X., Miao, S., Zhang, J., Zhang, S., et al. (2013). Anticancer effects of bufalin on human hepatocellular carcinoma HepG2 cells: roles of apoptosis and autophagy. Int. J. Mol. Sci. 14 (1), 1370-1382. doi: 10.3390/ ijms 14011370

Monge-Fuentes, V., Arenas, C., Galante, P., Goncalves, J. C., Mortari, M. R., and Schwartz, E. F. (2018). Arthropod toxins and their antinociceptive properties: From venoms to painkillers. Pharmacol. Ther. 188, 176-185. doi: 10.1016/ j.pharmthera.2018.03.007

Moreno, M., and Giralt, E. (2015). Three valuable peptides from bee and wasp venoms for therapeutic and biotechnological use: melittin, apamin and mastoparan. Toxins 7 (4), 1126-1150. doi: 10.3390/toxins7041126

Morita, T., Iwanaga, S., and Suzuki, T. (1976). The mechanism of activation of bovine prothrombin by an activator isolated from Echis carinatus venon and characterization of the new active intermediates. J. Biochem. 79 (5), 1089-1108. doi: 10.1093/oxfordjournals.jbchem.a131150

Morita, T. (2005). Structures and functions of snake venom CLPs (C-type lectinlike proteins) with anticoagulant-, procoagulant-, and platelet-modulating activities. Toxicon 45 (8), 1099-1114. doi: 10.1016/j.toxicon.2005.02.021

Mouhat, S., Visan, V., Ananthakrishnan, S., Wulff, H., Andreotti, N., Grissmer, S., et al. (2005). K+ channel types targeted by synthetic OSK1, a toxin from Orthochirus scrobiculosus scorpion venom. Biochem. J. 385 (Pt 1), 95-104. doi: 10.1042/BJ20041379

Mumcuoglu, K. Y. (2014). Recommendations for the use of leeches in reconstructive plastic surgery. Evid. Based Complement Alternat. Med. 2014, 205929. doi: 10.1155/2014/205929

Nascimento, F. D., Hayashi, M. A. F., Kerkis, A., Oliveira, V., Oliveira, E. B., RadisBaptista, G., et al. (2007). Crotamine mediates gene delivery into cells through the binding to heparan sulfate proteoglycans. J. Biol. Chem. 282 (29), 2134921360. doi: 10.1074/jbc.M604876200

Nauck, M. A., Duran, S., Kim, D., Johns, D., Northrup, J., Festa, A., et al. (2007). A comparison of twice-daily exenatide and biphasic insulin aspart in patients with type 2 diabetes who were suboptimally controlled with sulfonylurea and metformin: a non-inferiority study. Diabetologia 50 (2), 259-267. doi: 10.1007/ s00125-006-0510-2

Nicoletti, N. F., Erig, T. C., Zanin, R. F., Roxo, M. R., Ferreira, N. P., Gomez, M. V., et al. (2017). Pre-clinical evaluation of voltage-gated calcium channel blockers derived from the spider P. nigriventer in glioma progression. Toxicon 129, 5867. doi: 10.1016/j.toxicon.2017.02.001

NIH National Cancer Institute (2018). NCI Drug Dictionary - TRPV6 calcium channel inhibitor SOR-C13. Available at: https://www.cancer.gov/publications/ dictionaries/cancer-drug/def/trpv6-calcium-channel-inhibitor-sor-c13 (Accessed April 19, 2018) 
Nunes, K. P., Costa-Goncalves, A., Lanza, L. F., Cortes, S. F., Cordeiro, M. N., Richardson, M., et al. (2008). Tx2-6 toxin of the Phoneutria nigriventer spider potentiates rat erectile function. Toxicon 51 (7), 1197-1206. doi: 10.1016/ j.toxicon.2008.02.010

Nutescu, E. A., and Wittkowsky, A. K. (2004). Direct thrombin inhibitors for anticoagulation. Ann. Pharmacother. 38 (1), 99-109. doi: 10.1345/aph.1D066

Odegard, P. S., and Desantis, A. (2009). Recent results of exenatide use as adjunctive therapy in the treatment of patients with type 2 diabetes. Diabetes Metab. Syndr. Obes. 2, 135-144. doi: 10.2147/DMSO.S4444

Ojeda, P. G., Wang, C. K., and Craik, D. J. (2016). Chlorotoxin: Structure, activity, and potential uses in cancer therapy. Biopolymers 106 (1), 25-36. doi: 10.1002/ bip. 22748

Ojeda, P. G., Ramirez, D., Alzate-Morales, J., Caballero, J., Kaas, Q., and Gonzalez, W. (2018). Computational studies of snake venom toxins. Toxins 10 (1), 8. doi: 10.3390/toxins 10010008

Okkerse, P., Hay, J. L., Sitsen, E., Dahan, A., Klaassen, E., Houghton, W., et al. (2017). Pharmacokinetics and pharmacodynamics of intrathecally administered Xen2174, a synthetic conopeptide with norepinephrine reuptake inhibitor and analgesic properties. Br. J. Clin. Pharmacol. 83 (4), 751-763. doi: 10.1111/bcp.13176

Oliveira, I. S., Ferreira, I. G., Alexandre-Silva, G. M., Cerni, F. A., Cremonez, C. M., Arantes, E. C., et al. (2019). Scorpion toxins targeting Kv1.3 channels: insights into immunosuppression. J. Venom. Anim. Toxins Incl. Trop. Dis. (25), e148118. doi: 10.1590/1678-9199-JVATITD-1481-18

Orientoxin Biotech Co. Ltd . (2019). Medicine, cobratide for injection. Available at: https://orientoxin.en.ec21.com/Medicine_Cobratide_for_Injection-9761674. html (Accessed December 19, 2019).

Ortiz, E., Gurrola, G. B., Schwartz, E. F., and Possani, L. D. (2015). Scorpion venom components as potential candidates for drug development. Toxicon 93, 125-135. doi: 10.1016/j.toxicon.2014.11.233

Ouriel, K., Cynamon, J., Weaver, F. A., Dardik, H., Akers, D., Blebea, J., et al. (2005). A phase I trial of alfimeprase for peripheral arterial thrombolysis. $J$. Vasc. Interv. Radiol. 16 (8), 1075-1083. doi: 10.1097/01.RVI.0000167863. 10122.2A

Ovsepian, S. V., O’Leary, V. B., Ayvazyan, N. M., Al-Sabi, A., Ntziachristos, V., and Dolly, J. O. (2019). Neurobiology and therapeutic applications of neurotoxins targeting transmitter release. Pharmacol. Ther. 193, 135-155. doi: 10.1016/j.pharmthera.2018.08.016

Patchett, A. A. (1984). The chemistry of enalapril. Br. J. Clin. Pharmacol. 18 Suppl 2, 201S-207S. doi: 10.1111/j.1365-2125.1984.tb02599.x

Patil, C. G., Walker, D. G., Miller, D. M., Butte, P., Morrison, B., Kittle, D. S., et al. (2019). Phase 1 safety, pharmacokinetics, and fluorescence imaging study of tozuleristide (BLZ-100) in adults with newly diagnosed or recurrent gliomas. Neurosurgery 85 (4), E641-E648. doi: 10.1093/neuros/nyz125

Peigneur, S., de Lima, M. E., and Tytgat, J. (2018). Phoneutria nigriventer venom: A pharmacological treasure. Toxicon 151, 96-110. doi: 10.1016/j.toxicon. 2018.07.008

Pennington, M. W., Beeton, C., Galea, C. A., Smith, B. J., Chi, V., Monaghan, K. P., et al. (2009). Engineering a stable and selective peptide blocker of the Kv1.3 channel in T lymphocytes. Mol. Pharmacol. 75 (4), 762-773. doi: 10.1124/ mol.108.052704

Pennington, M. W., Czerwinski, A., and Norton, R. S. (2017). Peptide therapeutics from venom: Current status and potential. Bioorg. Med. Chem. 26, 2738-2758. doi: 10.1016/j.bmc.2017.09.029

Pentapharm DSM Nutritional Products Ltd (2018). Defibrase ${ }^{\circledR}$. Available at: http:// www.pentapharm.com/content.cfm ? nav $=21 \&$ content $=39 \& \mathrm{CFID}=$ 31651415\&CFTOKEN=27339979\&jsessionid=ae30b7ebec2f381e5bb64c68363f7 3c6f813 (Accessed March 15, 2018).

Pinto, A. F. M., Silva, K., and Guimaraes, J. A. (2006). Proteases from Lonomia obliqua venomous secretions: Comparison of procoagulant, fibrin(ogen)olytic and amidolytic activities. Toxicon 47 (1), 113-121. doi: 10.1016/j.toxicon.2005. 10.004

Pizzo, S. V., Schwartz, M. L., Hill, R. L., and McKee, P. A. (1972). Mechanism of ancrod anticoagulation. A direct proteolytic effect on fibrin. J. Clin. Invest. 51 (11), 2841-2850. doi: 10.1172/JCI107107

Plateltex, S. R. O. (2016). Plateltex - Device for the activation (gelification) of blood components destined to the topical non-transfusional use (Czech Republic:
Praha). Available at: http://www.plateltex.com/data/pdf/IFU4.3plateltex ACTJUNE2016ENG.pdf (Accessed March 19, 2020).

Plateltex, S. R. O. (2018). Plateltex - biologicals, clinical use, information sheet (Prague, Czech Republic). Available at: https://www.plateltex.com/ (Accessed April 19, 2018).

Pope, J. E., and Deer, T. R. (2013). Ziconotide: a clinical update and pharmacologic review. Expert Opin. Pharmacother. 14 (7), 957-966. doi: 10.1517/ 14656566.2013.784269

Pucca, M. B., Bertolini, T. B., Cerni, F. A., Bordon, K. C. F., Peigneur, S., Tytgat, J., et al. (2016). Immunosuppressive evidence of Tityus serrulatus toxins Ts6 and Ts15: insights of a novel $\mathrm{K}+$ channel pattern in T cells. Immunology 147 (2), 240-250. doi: 10.1111/imm.12559

Qi, F., Li, A., Inagaki, Y., Kokudo, N., Tamura, S., Nakata, M., et al. (2011). Antitumor activity of extracts and compounds from the skin of the toad Bufo bufo gargarizans Cantor. Int. Immunopharmacol. 11 (3), 342-349. doi: 10.1016/j.intimp.2010.12.007

Qin, T. J., Zhao, X. H., Yun, J., Zhang, L. X., Ruan, Z. P., and Pan, B. R. (2008). Efficacy and safety of gemcitabine-oxaliplatin combined with huachansu in patients with advanced gallbladder carcinoma. World J. Gastroenterol. 14 (33), 5210-5216. doi: 10.3748/wjg.14.5210

Ram, N., Jaumain, E., Ronjat, M., Pirollet, F., and De Waard, M. (2009). "Maurocalcinederivatives as biotechnological tools for the penetration of cell-impermeable compounds," in Animal toxins: state of the art-perspectives in health and biotechnology, 1st ed. Eds. M. E. D. Lima, A. M. D. C. Pimenta, M. F. MartinEauclaire, R. B. Zingali and H. Rochat (Belo Horizonte: Editora UFMG), 715-732.

Ramsey, J. D., and Flynn, N. H. (2015). Cell-penetrating peptides transport therapeutics into cells. Pharmacol. Ther. 154, 78-86. doi: 10.1016/ j.pharmthera.2015.07.003

Reid, P. F., and Raymond, L. N. (2010). Modified elapid venoms as stimulators of the immune reaction, 11/592896 application number.

Reid, H. A. (1971). Therapeutic defibrination by ancrod (Arvin). Folia Haematol. Int. Mag. Klin. Morphol. Blutforsch. 95 (2), 209-215.

Reid, P. F. (2007). Alpha-cobratoxin as a possible therapy for multiple sclerosis: a review of the literature leading to its development for this application. Crit. Rev. Immunol. 27 (4), 291-302. doi: 10.1615/CritRevImmunol.v27.i4.10

Reis, C. V., Andrade, S. A., Ramos, O. H. P., Ramos, C. R. R., Ho, P. L., Batista, I. D. C., et al. (2006). Lopap, a prothrombin activator from Lonomia obliqua belonging to the lipocalin family: recombinant production, biochemical characterization and structure-function insights. Biochem. J. 398, 295-302. doi: 10.1042/bj20060325

Ren, Y. D., Li, C. C., Chang, J. L., Wang, R., Wang, Y. H., and Chu, X. P. (2018). $\mathrm{Hila}$ as a novel neuroprotective agent for ischemic stroke by inhibition of acidsensing ion channel 1a. Transl. Stroke Res. 9 (2), 96-98. doi: 10.1007/s12975017-0575-X

Rigo, F. K., Trevisan, G., De Pra, S. D. T., Cordeiro, M. N., Borges, M. H., Silva, J. F., et al. (2017). The spider toxin Pho1 $\beta$ recombinant possesses strong analgesic activity. Toxicon 133, 145-152. doi: 10.1016/j.toxicon.2017.05.018

Romero, H. K., Christensen, S. B., Mannelli, L. D., Gajewiak, J., Ramachandra, R., Elmslie, K. S., et al. (2017). Inhibition of $\alpha 9 \alpha 10$ nicotinic acetylcholine receptors prevents chemotherapy-induced neuropathic pain. Proc. Natl. Acad. Sci. U.S.A. 114 (10), E1825-E1832. doi: 10.1073/pnas.1621433114

Römisch, J., Diehl, K. H., Hoffmann, D., Krahl-Mateblowski, U., Reers, M., Stüber, W., et al. (1993). Comparison of in vitro and in vivo properties of rhirudin (HBW 023) and a synthetic analogous peptide. Haemostasis 23 (5), 249-258. doi: $10.1159 / 000216883$

RxList (2019). Search. Available at: https://www.rxlist.com/script/main/hp.asp (Accessed December 19, 2019)

Salehi, B., Sestito, S., Rapposelli, S., Peron, G., Calina, D., Sharifi-Rad, M., et al. (2019). Epibatidine: a promising natural alkaloid in health. Biomolecules 9 (1):6. doi: 10.3390/biom9010006

Sample, C. J., Hudak, K. E., Barefoot, B. E., Koci, M. D., Wanyonyi, M. S., Abraham, S., et al. (2013). A mastoparan-derived peptide has broad-spectrum antiviral activity against enveloped viruses. Peptides 48, 96-105. doi: 10.1016/ j.peptides.2013.07.014

Santos, L. D., Pieroni, M., Menegasso, A. R. S., Pinto, J., and Palma, M. S. (2011). A new scenario of bioprospecting of Hymenoptera venoms through proteomic approach. J. Venom. Anim. Toxins Incl. Trop. Dis. 17 (4), 364-377. doi: 10.1590/S1678-91992011000300004 
Sato, A. C., Bosch, R. V., Will, S. E. A., Alvarez-Flores, M. P., Goldfeder, M. B., Pasqualoto, K. F. M., et al. (2016). Exploring the in vivo wound healing effects of a recombinant hemolin from the caterpillar Lonomia obliqua. J. Venom. Anim. Toxins Incl. Trop. Dis. 22, 36. doi: 10.1186/s40409-016-0093-4

Scannell, J. W., Blanckley, A., Boldon, H., and Warrington, B. (2012). Diagnosing the decline in pharmaceutical R\&D efficiency. Nat. Rev. Drug Discovery 11 (3), 191-200. doi: 10.1038/nrd3681

Scarborough, R. M., Rose, J. W., Hsu, M. A., Phillips, D. R., Fried, V. A., Campbell, A. M., et al. (1991). Barbourin. A GPIIb-IIIa-specific integrin antagonist from the venom of Sistrurus m. barbouri. J. Biol. Chem. 266 (15), 9359-9362.

Scarborough, R. M., Naughton, M. A., Teng, W., Rose, J., Phillips, D., Nannizzi, L., et al. (1993). Design of potent and specific integrin antagonists. Peptide antagonists with high specificity for glycoprotein IIb-IIIa. J. Biol. Chem. 268 (2), 1066-1073.

Scarborough, R. M. (1999). Development of eptifibatide. Am. Heart J. 138 (6), 1093-1104. doi: 10.1016/s0002-8703(99)70075-x

Schechter, M. E., Andrade, B. B., He, T., Richter, G. H., Tosh, K. W., Policicchio, B. B., et al. (2017). Inflammatory monocytes expressing tissue factor drive SIV and HIV coagulopathy. Sci. Transl. Med. 9 (405), eaam5441. doi: 10.1126/ scitranslmed.aam5441

Schwartsmann, G., DiLeone, L. P., Horowitz, M., Schunemann, D., Cancella, A., Pereira, A. S., et al. (2006). A phase I trial of the bombesin/gastrin-releasing peptide (BN/GRP) antagonist RC3095 in patients with advanced solid malignancies. Invest. New Drugs 24 (5), 403-412. doi: 10.1007/s10637-006-6886-5

Scott, D. A., Wright, C. E., and Angus, J. A. (2002). Actions of intrathecal omegaconotoxins CVID, GVIA, MVIIA, and morphine in acute and neuropathic pain in the rat. Eur. J. Pharmacol. 451 (3), 279-286. doi: 10.1016/S0014-2999 (02)02247-1

Seon, G. M., Lee, M. H., Kwon, B. J., Kim, M. S., Koo, M. A., Kim, D., et al. (2017). Functional improvement of hemostatic dressing by addition of recombinant batroxobin. Acta Biomater. 48, 175-185. doi: 10.1016/j.actbio.2016.10.024

Serrano, S. M. T. (2013). The long road of research on snake venom serine proteinases. Toxicon 62, 19-26. doi: 10.1016/j.toxicon.2012.09.003

Shah, A. R., and Scher, L. (2007). Drug evaluation: alfimeprase, a plasminogenindependent thrombolytic. IDrugs 10 (5), 329-335.

Shi, L., Liang, F., Li, Y., Shao, A., Zhou, K., Yu, J., et al. (2016). Desmoteplase for acute ischemic stroke within 3 to 9 Hours after symptom onset: Evidence from randomized controlled trials. Sci. Rep. 6:33989. doi: 10.1038/srep33989

Shibao, P. Y. T., Cologna, C. T., Morandi, R., Wiezel, G. A., Fujimura, P. T., UeiraVieira, C., et al. (2018). Deep sequencing analysis of toad Rhinella schneideri skin glands and partial biochemical characterization of its cutaneous secretion. J. Venom. Anim. Toxins Incl. Trop. Dis. 24, 36. doi: 10.1186/s40409-018-0173-8

Sig, A. K., Guney, M., Uskudar Guclu, A., and Ozmen, E. (2017). Medicinal leech therapy - an overall perspective. Integr. Med. Res. 6 (4), 337-343. doi: 10.1016/ j.imr.2017.08.001

Silva, C. N., Nunes, K. P., Torres, F. S., Cassoli, J. S., Santos, D. M., Almeida, F. D., et al. (2015). PnPP-19, a synthetic and nontoxic peptide designed from a Phoneutria nigriventer toxin, potentiates erectile function via NO/cGMP. J. Urol 194 (5), 1481-1490. doi: 10.1016/j.juro.2015.06.081

Singh, K., Davies, G., Alenazi, Y., Eaton, J. R. O., Kawamura, A., and Bhattacharya, S. (2017). Yeast surface display identifies a family of evasins from ticks with novel polyvalent CC chemokine-binding activities. Sci. Rep. 7 (1), 4267. doi: 10.1038/s41598-017-04378-1

Singh, A. P. (2010). Medicinal leech therapy (hirudotherapy): a brief overview. Complement Ther. Clin. Pract. 16 (4), 213-215. doi: 10.1016/j.ctcp.2009.11.005

Siramshetty, V. B., Nickel, J., Omieczynski, C., Gohlke, B. O., Drwal, M. N., and Preissner, R. (2016). Withdrawn - a resource for withdrawn and discontinued drugs. Nucleic Acids Res. 44 (D1), D1080-D1086. doi: 10.1093/nar/gkv1192

Smith, H. S., and Deer, T. R. (2009). Safety and efficacy of intrathecal ziconotide in the management of severe chronic pain. Ther. Clin. Risk Manag. 5 (3), 521534. doi: 10.2147/TCRM.S4438

Song, Y. M., Tang, X. X., Chen, X. G., Gao, B. B., Gao, E., Bai, L., et al. (2005). Effects of scorpion venom bioactive polypolypeptides on platelet aggregation and thrombosis and plasma 6-keto-PG F1alpha and TXB2 in rabbits and rats. Toxicon 46 (2), 230-235. doi: 10.1016/j.toxicon.2005.04.012

Soricimed (2018). SOR-C13 clinical development program - A first-in-class drug candidate in development for the treatment of solid-tumor cancer. Available at: https://www.soricimed.com/sor-c13.htm (Accessed April 19, 2018).
Souza, A. H., Ferreira, J., Cordeiro Mdo, N., Vieira, L. B., De Castro, C. J., Trevisan, G., et al. (2008). Analgesic effect in rodents of native and recombinant Pho1 $\beta$ toxin, a high-voltage-activated calcium channel blocker isolated from armed spider venom. Pain 140 (1), 115-126. doi: 10.1016/j.pain.2008.07.014

Spotnitz, W. D. (2014). Fibrin sealant: The only approved hemostat, sealant, and adhesive - a laboratory and clinical perspective. ISRN Surg. 2014:203943. doi: $10.1155 / 2014 / 203943$

Stocker, K., Fischer, H., and Meier, J. (1988). Practical application of the protein C activator Protac from Agkistrodon contortrix venom. Folia Haematol. Int. Mag. Klin. Morphol. Blutforsch. 115 (3), 260-264.

Stocker, K. (1978). "Defibrinogenation with thrombin-like snake venom enzymes," in Fibrinolytics and antifibrinolytics. Ed. F. Markwardt (Berlin, Heidelberg, New York: Springer-Verlag), 451-484.

Stransky, S., Costal-Oliveira, F., Lopes-de-Souza, L., Guerra-Duarte, C., ChavezOlortegui, C., and Braga, V. M. M. (2018). In vitro assessment of cytotoxic activities of Lachesis muta muta snake venom. PloS Negl. Trop. Dis. 12 (4), e0006427. doi: 10.1371/journal.pntd.0006427

Su, Y., Huang, X., Zhang, D., Zhang, Y., Xie, J., and Linh, C. (2003). HPLC separation and determination of bufadienolide in cinobufacini injection. Chin. Tradit. Pat. Med. 25, 24-27.

Swenson, S., Toombs, C. F., Pena, L., Johansson, J., and Markland, F. S. (2004). Alpha-fibrinogenases. Curr. Drug Targets Cardiovasc. Haematol. Disord. 4 (4), 417-435. doi: 10.2174/1568006043335754

Swenson, S., and Markland, F. S. (2013). "Fibrolase," in Handbook of proteolytic enzymes. Eds. N. D. Rawlings and G. Salvesen (Amsterdam: Elsevier), 972-976.

Tabacova, S. A., and Kimmel, C. A. (2001). Enalapril: pharmacokinetic/dynamic inferences for comparative developmental toxicity - A review. Reprod. Toxicol. 15 (5), 467-478. doi: 10.1016/s0890-6238(01)00161-7

Tamimi, N. A. M., and Ellis, P. (2009). Drug development: from concept to marketing! Nephron Clin. Pract. 113 (3), C125-C131. doi: 10.1159/000232592

Tanner, M. R., Tajhya, R. B., Huq, R., Gehrmann, E. J., Rodarte, K. E., Atik, M. A., et al. (2017). Prolonged immunomodulation in inflammatory arthritis using the selective Kv1.3 channel blocker HsTX1 R14A and its PEGylated analog. Clin. Immunol. 180, 45-57. doi: 10.1016/j.clim.2017.03.014

Tans, G., and Rosing, J. (2001). Snake venom activators of factor X: an overview. Haemostasis 31 (3-6), 225-233. doi: 10.1159/000048067

Tansi, F. L., Filatova, M. P., Koroev, D. O., Volpina, O. M., Lange, S., Schumann, C., et al. (2019). New generation CPPs show distinct selectivity for cancer and noncancer cells. J. Cell Biochem. 120 (4), 6528-6541. doi: 10.1002/jcb.27943

Tarcha, E. J., Chi, V., Munoz-Elias, E. J., Bailey, D., Londono, L. M., Upadhyay, S. K., et al. (2012). Durable pharmacological responses from the peptide ShK-186, a specific Kv1.3 channel inhibitor that suppresses T cell mediators of autoimmune disease. J. Pharmacol. Exp. Ther. 342 (3), 642-653. doi: 10.1124/jpet.112.191890

Tcheng, J. E., and O'Shea, J. C. (2002). Eptifibatide: a potent inhibitor of the platelet receptor integrin glycoprotein IIb/IIIa. Expert OpinPharmacother. 3 (8), 1199-1210. doi: 10.1517/14656566.3.8.1199

Tokunaga, F., Nagasawa, K., Tamura, S., Miyata, T., Iwanaga, S., and Kisiel, W. (1988). The factor V-activating enzyme (RVV-V) from Russell's viper venom. Identification of isoproteins $\mathrm{RVV}-\mathrm{V}$ alpha, $-\mathrm{V}$ beta, and $-\mathrm{V}$ gamma and their complete amino acid sequences. J. Biol. Chem. 263 (33), 17471-17481.

Topol, E. J., Byzova, T. V., and Plow, E. F. (1999). Platelet GPIIb-IIIa blockers. Lancet 353 (9148), 227-231. doi: 10.1016/S0140-6736(98)11086-3

Tornesello, A. L., Buonaguro, L., Tornesello, M. L., and Buonaguro, F. M. (2017). New insights in the design of bioactive peptides and chelating agents for imaging and therapy in oncology. Molecules 22 (8):1282. doi: 10.3390/ molecules 22081282

Traynor, J. R. (1998). Epibatidine and pain. Br. J. Anaesth. 81 (1), 69-76. doi: 10.1093/bja/81.1.69

Trifiro, G., Gini, R., Barone-Adesi, F., Beghi, E., Cantarutti, A., Capuano, A., et al. (2019). The role of European healthcare databases for post-marketing drug effectiveness, safety and value evaluation: where does Italy stand? Drug Safe 42 (3), 347-363. doi: 10.1007/s40264-018-0732-5

Trujillo, J. M., and Goldman, J. (2017). Lixisenatide, a once-daily prandial glucagon-like peptide-1 receptor agonist for the treatment of adults with type 2 diabetes. Pharmacotherapy 37 (8), 927-943. doi: 10.1002/phar.1962

Umana, I. C., Daniele, C. A., and McGehee, D. S. (2013). Neuronal nicotinic receptors as analgesic targets: it's a winding road. Biochem. Pharmacol. 86 (8), 1208-1214. doi: 10.1016/j.bcp.2013.08.001 
US Food and Drug Administration (2016). FDA approves Adlyxin to treat type 2 diabetes (Accessed March 30, 2020).

US Food and Drug Administration (2020). Drugs FDA: FDA approved drug products. Available at: https://www.accessdata.fda.gov/scripts/cder/daf/ (Accessed June 25, 2020).

US National Library of Medicine (2020). ClinicalTrials.gov - Find a study. Available at: https://clinicaltrials.gov/ (Accessed June 25, 2020).

Utkin, Y. N., Vassilevski, A. A., Kudryavtsev, D., and Undheim, E. A. B. (2019). Animal toxins as comprehensive pharmacological tools to identify diverse ion channels. Front. Pharmacol. 10, 423. doi: 10.3389/fphar.2019.00423

Utkin, Y. N. (2017). Modern trends in animal venom research - omics and nanomaterials. World J. Biol. Chem. 8 (1), 4-12. doi: 10.4331/wjbc.v8.i1.4

Valverde, P., Kawai, T., and Taubman, M. A. (2004). Selective blockade of voltagegated potassium channels reduces inflammatory bone resorption in experimental periodontal disease. J. Bone Miner. Res. 19 (1), 155-164. doi: 10.1359/JBMR.0301213

Varga, Z., Gurrola-Briones, G., Papp, F., Rodriguez de la Vega, R. C., PedrazaAlva, G., Tajhya, R. B., et al. (2012). Vm24, a natural immunosuppressive peptide, potently and selectively blocks Kv1.3 potassium channels of human $\mathrm{T}$ cells. Mol. Pharmacol. 82 (3), 372-382. doi: 10.1124/mol.112.078006

Veiga, A. B., Ribeiro, J. M., Guimarães, J. A., and Francischetti, I. M. (2005). A catalog for the transcripts from the venomous structures of the caterpillar Lonomia obliqua: identification of the proteins potentially involved in the coagulation disorder and hemorrhagic syndrome. Gene 355, 11-27. doi: $10.1016 /$ j.gene.2005.05.002

Veiga, A. B. G., Berger, M., and Guimarães, J. A. (2009). "Lonomia obliqua venom: pharmaco-toxicological effects and biotechnological perspectives," in Animal toxins: state of the art - perspectives in health and biotechnology, 1st ed. Eds. M. E. D. Lima, A. M. D. C. Pimenta, M. F. Martin-Eauclaire, R. B. Zingali and H. Rochat (Belo Horizonte: Editora UFMG), 371-390.

Veiseh, M., Gabikian, P., Bahrami, S. B., Veiseh, O., Zhang, M., Hackman, R. C., et al. (2007). Tumor paint: a chlorotoxin:Cy5.5 bioconjugate for intraoperative visualization of cancer foci. Cancer Res. 67 (14), 6882-6888. doi: 10.1158/00085472.CAN-06-3948

Verdoni, M., Roudaut, H., De Pomyers, H., Gigmes, D., Bertin, D., Luis, J., et al. (2016). ArgTX-636, a polyamine isolated from spider venom: A novel class of melanogenesis inhibitors. Bioorgan. Med. Chem. 24 (22), 5685-5692. doi: 10.1016/j.bmc.2016.08.023

Vetter, I., Deuis, J. R., Mueller, A., Israel, M. R., Starobova, H., Zhang, A., et al. (2017). $\mathrm{Na}_{\mathrm{V}} 1.7$ as a pain target - From gene to pharmacology. Pharmacol. Ther. 172, 73-100. doi: 10.1016/j.pharmthera.2016.11.015

Veytia-Bucheli, J. I., Jimenez-Vargas, J. M., Melchy-Perez, E. I., Sandoval-Hernandez, M. A., Possani, L. D., and Rosenstein, Y. (2018). Kv1.3 channel blockade with the Vm24 scorpion toxin attenuates the CD4+ effector memory T cell response to TCR stimulation. J. Cell Commun. Signal 16, 45. doi: 10.1186/s12964-018-0257-7

Vila-Farres, X., Giralt, E., and Vila, J. (2012). Update of peptides with antibacterial activity. Curr. Med. Chem. 19 (36), 6188-6198. doi: 10.2174/092986712 804485818

Vink, S., and Alewood, P. F. (2012). Targeting voltage-gated calcium channels: developments in peptide and small-molecule inhibitors for the treatment of neuropathic pain. Br. J. Pharmacol. 167 (5), 970-989. doi: 10.1111/j.1476$5381.2012 .02082 . \mathrm{x}$

Vivostat A/S (2018). Vivostat autologous fibrin sealant (Medicon Valley: Scandinavia). Available at: https://www.vivostat.com/products/vivostatfibrin-sealant (Accessed April 19, 2018).

Vu, T. T., Stafford, A. R., Leslie, B. A., Kim, P. Y., Fredenburgh, J. C., and Weitz, J. I. (2013). Batroxobin binds fibrin with higher affinity and promotes clot expansion to a greater extent than thrombin. J. Biol. Chem. 288 (23), 1686216871. doi: 10.1074/jbc.M113.464750

Warkentin, T. E. (2004). Bivalent direct thrombin inhibitors: hirudin and bivalirudin. Best Pract. Res. Clin. Haematol. 17 (1), 105-125. doi: 10.1016/ j.beha.2004.02.002

Watters, M. R. (2005). Tropical marine neurotoxins: Venoms to drugs. Semin. Neurol. 25 (3), 278-289. doi: 10.1055/s-2005-917664

Weber, M. A., Schiffrin, E. L., White, W. B., Mann, S., Lindholm, L. H., Kenerson, J. G., et al. (2014). Clinical practice guidelines for the management of hypertension in the community: a statement by the American Society of
Hypertension and the International Society of Hypertension. J. Clin. Hypertens. 16 (1), 14-26. doi: 10.1111/jch.12237

Wei, C. M., Aarhus, L. L., Miller, V. M., and Burnett, J. C. (1993). Action of C-type natriuretic peptide in isolated canine arteries and veins. Am. J. Physiol. 264 (1 Pt 2), H71-H73. doi: 10.1152/ajpheart.1993.264.1.H71

Wei, J. M., Zhu, M. W., Zhang, Z. T., Jia, Z. G., He, X. D., Wan, Y. L., et al. (2010). A multicenter, phase III trial of hemocoagulase Agkistrodon: hemostasis, coagulation, and safety in patients undergoing abdominal surgery. Chin. Med. J. (Engl) 123 (5), 589-593.

Weinger, R. S., Rudy, C., Moake, J. L., Olson, J. D., and Cimo, P. L. (1980). Prothrombin Houston: a dysprothrombin identifiable by crossed immunoelectrofocusing and abnormal Echis carinatus venom activation. Blood 55 (5), 811-816.

Wieser, G., Mansi, R., Grosu, A. L., Schultze-Seemann, W., Dumont-Walter, R. A., Meyer, P. T., et al. (2014). Positron emission tomography (PET) imaging of prostate cancer with a gastrin releasing peptide receptor antagonist - from mice to men. Theranostics 4 (4), 412-419. doi: 10.7150/thno.7324

Wigger, E., Kuhn-Nentwig, L., and Nentwig, W. (2002). The venom optimisation hypothesis: a spider injects large venom quantities only into difficult prey types. Toxicon 40 (6), 749-752. doi: 10.1016/s0041-0101(01)00277-x

Wilson, D., and Daly, N. L. (2018). Venomics: A mini-review. High Throughput 7 (3), 19. doi: 10.3390/ht7030019

Wong, C. K. (2005). Should bivalirudin be the anticoagulant of choice for percutaneous coronary intervention? Nat. Clin. Pract. Cardiovasc. Med. 2 (8), 384-385. doi: 10.1038/ncpcardio0277

Wysham, C. H., Rosenstock, J., Vetter, M. L., Dong, F., Öhman, P., and Iqbal, N. (2017). Efficacy and tolerability of the new autoinjected suspension of exenatide once weekly versus exenatide twice daily in patients with type 2 diabetes. Diabetes Obes. Metab. 20, 165-172. doi: 10.1111/dom.13056

Xie, X. B., Yin, J. Q., Wen, L. L., Gao, Z. H., Zou, C. Y., Wang, J., et al. (2012). Critical role of heat shock protein 27 in bufalin-induced apoptosis in human osteosarcomas: a proteomic-based research. PloS One 7 (10), e47375. doi: 10.1371/journal.pone.0047375

Xie, X., Huang, X., Li, J., Lv, X., Huang, J., Tang, S., et al. (2013). Efficacy and safety of Huachansu combined with chemotherapy in advanced gastric cancer: a meta-analysis. Med. Hypotheses 81 (2), 243-250. doi: 10.1016/j.mehy .2013 .04 .038

Xu, Y. Y., Ma, X. H., and Zhang, S. J. (2016). Hemocoagulase agkistrodon-induced anaphylactic shock: A case report and literature review. Int. J. Clin. Pharmacol. Ther. 54 (2), 129-134. doi: 10.5414/CP202296

Yang, R., Peng, F., Liu, H., Cao, Z. J., Li, W. X., Mao, X., et al. (2005). Functional analysis of a gene encoding a chlorotoxin-like peptide derived from scorpion toxin. Chin. J. Biochem. Mol. Biol. 21 (1), 19-23.

Yang, M., Huo, X. C., Miao, Z. R., and Wang, Y. J. (2019). Platelet glycoprotein IIb/ IIIa receptor inhibitor tirofiban in acute ischemic stroke. Drugs 79 (5), 515529. doi: 10.1007/s40265-019-01078-0

You, W. K., Choi, W. S., Koh, Y. S., Shin, H. C., Jang, Y., and Chung, K. H. (2004). Functional characterization of recombinant batroxobin, a snake venom thrombin-like enzyme, expressed from Pichia pastoris. FEBS Lett. 571 (1-3), 67-73. doi: 10.1016/j.febslet.2004.06.060

You, K. E., Koo, M. A., Lee, D. H., Kwon, B. J., Lee, M. H., Hyon, S. H., et al. (2014). The effective control of a bleeding injury using a medical adhesive containing batroxobin. BioMed. Mat. 9 (2):25002. doi: 10.1088/1748-6041/9/2/025002

Zambelli, V. O., Fernandes, A. C. D., Gutierrez, V. P., Ferreira, J. C. B., Parada, C. A., Mochly-Rosen, D., et al. (2014). Peripheral sensitization increases opioid receptor expression and activation by crotalphine in rats. PloS One 9 (3), e90576. doi: 10.1371/journal.pone.0090576

Zeymer, U. (2007). The role of eptifibatide in patients undergoing percutaneous coronary intervention. Expert Opin. Pharmacother. 8 (8), 1147-1154. doi: 10.1517/14656566.8.8.1147

Zhang, L. J., and Falla, T. J. (2009). Cosmeceuticals and peptides. Clin. Dermatol. 27 (5), 485-494. doi: 10.1016/j.clindermatol.2009.05.013

Zhang, Y. (2015). Why do we study animal toxins? Zool Res. 36 (4), 183-222. doi: 10.13918/j.issn.2095-8137.2015.4.183

Zhao, Y., Huang, J., Yuan, X., Peng, B., Liu, W., Han, S., et al. (2015). Toxins targeting the Kv1.3 channel: Potential immunomodulators for autoimmune diseases. Toxins 7 (5), 1749-1764. doi: 10.3390/toxins7051749 
Conflict of Interest: The authors declare that the research was conducted in the absence of any commercial or financial relationships that could be construed as a potential conflict of interest.

Copyright (C) 2020 Bordon, Cologna, Fornari-Baldo, Pinheiro-Júnior, Cerni, Amorim, Anjolette, Cordeiro, Wiezel, Cardoso, Ferreira, Oliveira, Boldrini-França, Pucca,
Baldo and Arantes. This is an open-access article distributed under the terms of the Creative Commons Attribution License (CC BY). The use, distribution or reproduction in other forums is permitted, provided the original author(s) and the copyright owner(s) are credited and that the original publication in this journal is cited, in accordance with accepted academic practice. No use, distribution or reproduction is permitted which does not comply with these terms. 